\title{
A integração das ações no campo da Saúde Mental entre a Estratégia de Saúde da Família e o Núcleo de Apoio à Saúde da Família: desafios para uma prática interdisciplinar.
}

\author{
(versão original)
}

Dissertação apresentada ao Instituto de Psicologia da Universidade de São Paulo como parte dos requisitos para obtenção do título em Mestre em Psicologia.

Área de concentração: Psicologia Social

Orientadora: Profa. Dra. Belinda Piltcher Haber Mandelbaum 
AUTORIZO A REPRODUÇÃO E DIVULGAÇÃO TOTAL OU PARCIAL DESTE TRABALHO, POR QUALQUER MEIO CONVENCIONAL OU ELETRÔNICO, PARA FINS DE ESTUDO E PESQUISA, DESDE QUE CITADA A FONTE.

Catalogação na publicação

Biblioteca Dante Moreira Leite

Instituto de Psicologia da Universidade de São Paulo

Oliveira, Fernanda Rodrigues Leite de.

A integração das ações no campo da saúde mental entre a estratégia de saúde da família e o Núcleo de Apoio à Saúde da Família: desafios para uma prática interdisciplinar / Fernanda Rodrigues Leite de Oliveira; orientadora Belinda Piltcher Haber Mandelbaum. -- São Paulo, 2013.

$116 \mathrm{f}$.

Dissertação (Mestrado - Programa de Pós-Graduação em Psicologia. Área de Concentração: Psicologia Social) - Instituto de Psicologia da Universidade de São Paulo.

1. Saúde da família 2. Promoção da saúde 3. Saúde Mental 4. Profissionais da saúde (Integração) 5. Interdisciplinaridade 6. Centros de saúde I. Título. 
OLIVEIRA, Fernanda Rodrigues Leite

A inte gração das ações no campo da Saúde Mental entre a Estratégia de Saúde da Família e o Núcleo de Apoio à Saúde da Família: desafios para uma prática interdisciplinar.

Dissertação apresentada ao Instituto de Psicologia da Universidade de São Paulo como parte dos requisitos para obtenção do título em Mestre em Psicologia.

Aprovado em:

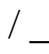
I

Banca Examinadora

Prof. Dr. Instituição:

Julgamento:

Assinatura:

Prof. Dr. Instituição:

Julgamento:

Assinatura:

Prof. Dr. Instituição:

Julgamento: Assinatura: 


\section{DEDICATÓRIA}

À minha mãe, Gecélia.

Que tantas vezes soube como ninguém ser "colo que acolhe, braço que envolve, palavra que conforta, silêncio que respeita, alegria que contagia, lágrima que corre, olhar que acaricia, desejo que sacia, amor que promove" (Cora Coralina). À minha neguinha que com sua força, sabedoria e alegria de viver compartilha comigo tantos projetos de vida.

Ao meu pai, Benedicto.

Pela presença que algumas vezes guardou no silêncio o respeito por minhas escolhas. Pela força que incentiva e que engrandece. Obrigada, por ter aceitado ser meu pai e por tantas vezes me dar as mãos para que eu pudesse, em paz, trilhar meu caminho. Ditinho, sua simplicidade e sabedoria são qualidades raras neste mundo. 


\section{AGRADECIMENTOS}

Aos profissionais da equipe de ESF e NASF, participantes deste estudo, por dividirem comigo algumas de suas experiências e inquietações geradas no cotidiano de trabalho. Obrigada pelo acolhimento e abertura para este encontro.

À querida professora Belinda, pela parceria e presença cuidadosa na construção deste trabalho. Obrigada pelos ensinamentos e por compartilhar comigo a realização deste projeto.

Às docentes que compõem a banca de defesa, Ianni Regia Scarcelli e Marina Peduzzi, pela disponibilidade em compartilhar conhecimentos e orientações. E também ao professor Bernardo S vartman pelas contribuições na ocasião da qualificação deste estudo.

Às queridas Nalva, Rosangela e Selma, que pacientemente me acompanharam neste percurso, sanando dúvidas e oferecendo orientações importantes.

Aos colegas de laboratório por, generosamente, terem lido as inúmeras versões de meu trabalho. Obrigad a pelas importantes contribuições e apoio.

Ao CNPq pelo financiamento deste estudo.

Ao meu irmão Luiz Fernando por ser a pessoa maravilhosa que é. Sua força e presença são fundamentais à minha vida. E também à minha cunhada Isabel e à minha sobrinha Thalyta por todo o suporte oferecido no percurso de composição deste trabalho.

À minha irmã Rose pelas nossas longas e importantes conversas e ao meu cunhado Nilton por ter desde sempre me incentivado a ler. E também aos meus sobrinhos Larissa e Filipe pela doçura e pelos sorrisos.

À Cirlene pelas comidinhas gostosas e pelo olhar sereno e companheiro de sempre.

À querida amiga Nadja pela presença na realização deste estudo e por compartilhar comigo tantos outros projetos de vida. Sua alegria vibrante e sua amizade me fortalecem.

Aos amigos Evelyn e Moreno. À Evelyn por me acompanhar nas angústias da vida e pelos convites à distração. Sua amizade engrandece. E ao Moreno pela escuta interessada e por ter oferecido orientações importantes para produção deste trabalho.

Ao Luis Felipe pelo incentivo e apoio desde sempre na construção deste projeto.

E, por fim, agradeço aos queridos amigos Luis Saraiva e Márcio Dionízio. Ao amigo Luis pelas valiosas contribuições e incentivos e pelas ótimas gargalhas. E ao querido Márcio pelo laço de amizade que pudemos construir. Obrigada pelos cafés e sorrisos confortantes. 


\section{RESUMO}

\section{Oliveira, F. R. L. A integração das ações no campo da Saúde Mental entre a Estratégia}

de Saúde da Família e o Núcleo de Apoio à Saúde da Família: desafios para uma prática interdisciplinar. 2013. 116 f. Dissertação (Mestrado) - Instituto de Psicologia, Universidade de São Paulo, São Paulo, 2013.

Com o intuito de superar os modelos tradicionais de atenção à saúde, caracterizados pela fragmentação e pelo elevado grau de especialização das intervenções, a Estratégia de Saúde da Família (ESF) foi criada como dispositivo prioritário para a reorganização do sistema de saúde. Para tanto, é composta por equipe multiprofissional que deve atuar no desenvolvimento de ações de promoção da saúde, prevenção de adoecimento, tratamento e reabilitação com foco no indivíduo, na família e na comunidade. Com o objetivo de ampliar e apoiar o trabalho da ESF, o Ministério da Saúde criou os Núcleos de Apoio à Saúde da Família (NASF). Tais núcleos são compostos por equipes multiprofissionais que devem operar de acordo com a lógica do Apoio Matricial, trabalhando de maneira conjunta com a ESF. Para isso, os profissionais do NASF desenvolvem algumas ações estraté gicas, como discussões de casos, realização de atendimentos compartilhados e ações de educação permanente. A partir da experiência profissional junto ao NASF foi possível verificar alguns impasses e dificuldades relacionados ao desenvolvimento das ações em Saúde Mental e também à integração das equipes de ESF e NASF. Que concepções de Saúde Mental e de cuidado guiam as ações? Como se dá a integração dos diferentes saberes e do trabalho entre os profissionais na construção de projetos terapêuticos? Frente a essas questões, este estudo objetiva discutir o panorama em que se insere a prática e a inte gração das ações em Saúde Mental desenvolvidas pelos profissionais da ESF e NASF. Para tanto, realizou-se uma pesquisa qualitativa orientada pelo estudo de caso sobre uma equipe de ESF e NASF atuante em uma Unidade Básica de Saúde localizada na região leste do município de São Paulo. O diálogo com os profissionais foi articulado por meio da observação de reuniões de equipe, da análise de prontuários e da realização de grupos focais. Percebeu-se que, embora a implantação do NASF tenha possibilitado alguns avanços no sentido de facilitar a interdisciplinaridade, tanto a prática em Saúde Mental quanto a relação que se estabelece entre os profissionais e entre estes e os usuários expressam os automatismos do agir orientado por uma compreensão "patologizante" do sofrimento psíquico. As práticas prescritivas repetem os ordenamentos que pretendiam superar. Além disso, os profissionais referem sentimentos de frustração e angústia diante de situações que envolvem o cuidado em Saúde Mental. A integração do trabalho entre os profissionais esteve permeada por questões relacionadas à burocratização, à valorização dos aspectos quantitativos de produção, à gestão verticalizada, às relações de poder e de dominação de determinadas formas de pensar e agir, tudo o que corrobora para que se reproduza o mesmo tipo de modelo da atenção ao qual a ESF e NASF procura substituir. Nesse contexto, considera-se que potencializar espaços de escuta, acolhimento, diálogo e negociação, viabilizando o vínculo a partir do encontro entre os técnicos e entre estes e os usuários seja uma forma de criar brechas para a estruturação de intervenções comprometidas com a complexidade dos processos de adoecimento, subjetivação e produção de vida.

Palavras chave: Saúde da Família, Promoção da Saúde, Saúde Mental, Profissionais da Saúde (Integração), Interdisciplinaridade, Centros de Saúde. 


\begin{abstract}
Oliveira, F. R. L. Integration of actions in the field of Mental Health between the Family Health Strategy and the Support Center for Family Health: challenges for an interdisciplinary practice. 2013. 116 p. Thesis (MA) - Institute of Psychology, University of São Paulo, São Paulo, 2013.

In order to overcome the traditional models of health care, characterized by fragmentation and a high degree of specialization of interventions, the Family Health Strategy (ESF) was created as a priority device for the reorganization of the health system. Therefore, it is composed of a multidisciplinary team that must work on developing actions that aim health promotion, disease prevention, treatment and rehabilitation with focus on the individual, family and community. With the purpose of expanding and supporting the work carried out by ESF, the Ministry of Health created the Support Centers for Family Health (NASF). Such centers are composed of multidisciplinary teams that must operate according to the logic of Matrix Support, therefore working jointly with ESF teams. In order to enable such joint action, professional members of NASF develop certain strategic actions such as case discussions, conducting shared visits and activities of continuing education. From the experience with the NASF, it was possible to verify some impasses and difficulties related to the development of actions in Mental Health, as well as the integration of ESF teams and NASF. What conceptions of Mental Health and Care are set forth in order to accomplish such actions? How are the diversity of knowledge and approaches of work among different professionals integrated in the development of therapeutic projects? Faced with these issues, the objective of this study is to discuss the setting in which the practice and integration of actions in the field of Mental Health developed by professionals from ESF and NASF are operated. To achieve such objective, we carried out a qualitative research-driven case study of an ESF and NASF team working together at a Basic Health Unit located in the eastern region of São Paulo. The dialogue with the professionals was articulated through the observation of team meetings, analysis of medical records and conduction of focus groups. It was noticed that while the deployment of NASF has enabled some progress in facilitating interdisciplinary work, both the Mental Health practice and the relationship established amongst professionals, and between the latter and their clients express a pattern of automatic guided actions governed by a potentially "pathologysing" understanding of psychological distress. Their prescribing practices tend to reproduce the very modus operandi that the teams meant to overcome. Furthermore, professionals express feelings of frustration and anguish in situations involving Mental Health care. The integration of work amongst professionals was permeated by issues related to bureaucracy, appreciation of the quantitative aspects of production, top down management models, relations of power and domination of certain ways of thinking and acting, all of which corroborate to the reproduction of the same model of care to which the ESF and NASF seek to replace. In this context, it is considered that the enhancement of settings that promote a space for listening, receptivity, dialogue and negotiation, allowing for the bonding that stems from such meetings, and from the relation between professionals and clients is a potential means to generate opportunities for structuring interventions committed to the complexity of processes related to mental illness, production of subjectivity and life.
\end{abstract}

Keywords: Family Health, Health Promotion, Mental Health, Health Professionals (Integration), Interdisciplinarity, Health Centers. 


\section{SUMÁRIO}

1. APR ESENTAÇÃ

2. OBJETIVO.......................................................................................................................................... 16

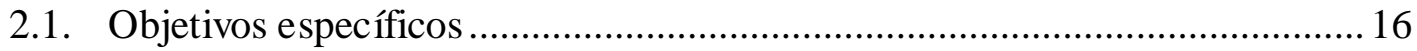

3. O PROCESSO DE TRABALHO NA ESTRATÉGIA DE SAÚDE DA FAMÍLIA E NO NÚCLEO DE APOIO À SAÚDE DA FAMÍLIA......................................................... 17

3.1. A Política Nacional de Atenção Básica à Saúde e a Estratégia de Saúde da

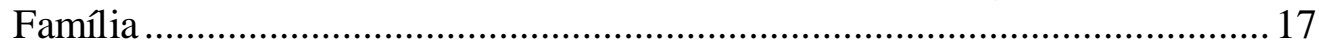

3.2. O Núcleo de Apoio à Saúde da Família .................................................... 21

3.3. A Saúde Mental na Estratégia de Saúde da Família e o Núcleo de Apoio à Saúde da Família .......................................................................................2 29

4. SOBRE A PESQUISA ...................................................................................................... 34

4.1. Conhecendo o campo de pesquisa: breve histórico sobre a implantação da ESF e NASF na região leste do município de São Paulo ............................... 34

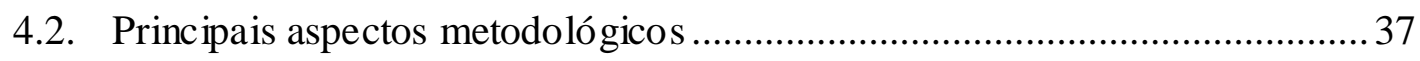

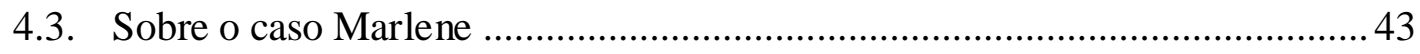

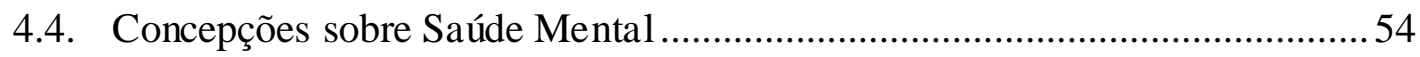

4.5. Como os profissionais se relacionam com o adoecimento mental................57

4.6. A prática: propostas, ações e principais dificuldades ..................................58

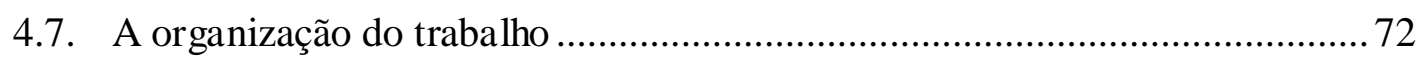

5. DISCUSSÃ

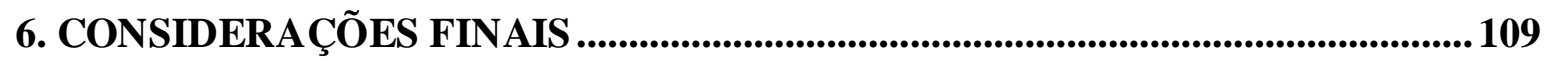




\section{APRESENTAÇÃO}

Este estudo decorre de uma série de inquietações suscitadas a partir da minha experiência profissional como terapeuta ocupacional de um Núcleo de Apoio à Saúde da Família (NASF) e como coordenadora desses núcleos, atuantes em Unidades Básicas de Saúde, em um bairro da região leste do município de São Paulo.

Segundo a Portaria GM n $n^{\circ}$ 154, de 24 de janeiro de 2008, o NASF deve ser composto por uma equipe multiprofissional, tendo como função apoiar as ações das equipes de Saúde da Família, com vistas a ampliar e qualificar suas possibilidades de intervenção e de aumentar sua resolutividade (BRASIL, 2008).

Com o intuito de viabilizar a articulação das ações entre as equipes de Saúde da Família e do NASF, os profissionais de tais núcleos devem desenvolver ações apoiadas em um tripé de ferramentas que envolvem: o Apoio Matricial, a Clínica Ampliada e o Projeto Terapêutico Singular.

O Apoio Matricial, embasado na interdisciplinaridade, é uma metodologia de trabalho que objetiva assegurar retaguarda especializada às equipes de Saúde da Família por meio do suporte técnico-assistencial e pedagógico. Para isso, as equipes devem estruturar espaços de trocas e discussões para a elaboração conjunta de projetos assistenciais, bem como viabilizar a realização de atendimentos compartilhados (CUNHA; CAMPOS, 2011).

Tal apoio apresenta como propósito a ampliação da clínica, o que significa que as ações devem ser fundamentadas em um modo de compreender o adoecimento para além das questões expressas no corpo biológico. Como aponta Cunha (2005), a Clínica Ampliada pretende o estabelecimento de abordagens a partir de concepções que buscam o reconhecimento dos determinantes universais e particulares envolvidos no processo de adoecimento.

Visando iluminar a singularidade e viabilizar o delineamento das intervenções realizadas pelas equipes de Saúde da Família e pelo NASF, o Projeto Terapêutico Singular é uma das ferramentas de suporte para a construção das ações. As reuniões de equipe e os atendimentos compartilhados são os espaços privilegiados para a discussão e elaboração de tais projetos terapêuticos (OLIVEIRA, 2008).

Tal arranjo organizacional do trabalho do NASF preconiza o desenvolvimento de atividades compartilhadas com as equipes de Saúde da Família, o que significa que este 
dispositivo tem como função a ativação de espaços de comunicação, de trocas de conhecimentos e de corresponsabilização pelos casos atendidos.

Segundo orientação apresentada nos Cadernos de Atenção Básica: Diretrizes do $N A S F$, a principal atribuição dos profissionais desse núcleo é o estabelecimento de um vínculo de confiança com os profissionais das equipes de Saúde da Família, para que possam desenvolver ações integradas. Integrar equipes não significa agregar e somar funções, mas sim propiciar espaços para o debate de ideias, o desenvolvimento da capacidade criadora e crítica, sendo esses aspectos fundamentais para o estabelecimento da interdisciplinaridade e do trabalho em equipe (BRASIL, 2009).

Como esclarece Peduzzi (2001), o trabalho em equipe é uma proposta que envolve a interação de um coletivo reunido em torno de uma situação a fim de se colocar em acordo a coordenação de um plano de ação - no caso da saúde, um plano de ação terapêutica. Para isso, pressupõe a existência de uma constante relação entre intervenções técnicas e interação entre os sujeitos que agem.

O trabalho em equipe, como apontam Schraiber et al. (1999), deve ser composto pelo compartilhamento de saberes e negociações para a tomada de decisões relacionadas ao estabelecimento da intervenções de cuidado. Tal concepção pressupõe o planejamento e a gestão compartilhada das ações.

Nessa perspectiva, a integração da equipe envolve aspectos relacionados à comunicação, ao caráter interdependente da autonomia técnica, à flexibilidade da divisão de tarefas, à possibilidade de construção de um projeto assistencial comum e à capacidade de compreensão sobre as diferenças técnicas como complementares, e não como desiguais (PEDUZZI, 2001).

A implantação do NASF na região em que este estudo foi desenvolvido ocorreu a partir de fevereiro de 2009, embora a portaria que estabelece sua regulamentação tenha sido publicada em janeiro de 2008. Ao longo de dois anos de minha atuação junto a essas equipes, fui tomada de algumas questões diante dos desafios relacionados à prática em situações que envolviam o adoecimento mental bem como a integração dos profissionais para a construção do trabalho em equipe.

A partir dessa experiência profissional, convido o leitor a conhecer a trajetória em que se apresentaram as primeiras inquietações e os principais desafios para a construção da prática articulada entre os profissionais das equipes de Saúde da Família e do NASF, tendo como foco as ações no campo da Saúde Mental. 
Para a implantação do NASF na região, foram contratados: terapeutas ocupacionais, psicólogos, fisioterapeutas, nutricionistas, entre outras categorias profissionais, para trabalhar orientados pela metodologia do Apoio Matricial. Fomos convocados a oferecer apoio à Estratégia de Saúde da Família. Mas como apoiar? Vamos atender as famílias ou devemos apenas oferecer suporte aos profissionais? Que tipo de suporte?

No cotidiano de trabalho junto às equipes de Saúde da Família, eram frequentes as solicitações para a realização de intervenções que envolviam situações de adoecimento mental. As primeiras reuniões de equipe já apontavam que essas questões eram motivo de preocupação para os profisssionais. Alguns diziam: “A gente precisa muito de atendimento, principalmente na Saúde Mental, porque não tem psiquiatra e as filas de espera são grandes".

As principais demandas de atendimentos em Saúde Mental relacionavam-se às pessoas vivenciando situações de violência, às crianças encaminhadas pelas escolas com queixas de comportamento e dificuldade de aprendizagem, às solicitações de atendimento vindas do conselho tutelar, aos usuários de drogas e seus familiares, aos pedidos de atestado para perícias, aos "poliqueixosos", aos deprimidos, entre outros. Como lidar com situações marcadas por questões de ordens diversas, que extrapolam o âmbito da clínica tradicional?

Apesar das diferentes propostas de cuidado ofertadas, havia por parte das equipes de Saúde da Família a procura incessante por consultas com especialistas e por prescrições de medicamentos, mesmo quando essas intervenções já tinham sido desenvolvidas, muitas vezes sem sucesso. Frente a esse cenário, destacava-se a insuficiência de ações focadas apenas nos sintomas relacionados ao adoecimento mental, e os profissionais, geralmente, mostravam-se insatisfeitos diante dos resultados obtidos em suas intervenções.

Parecia haver a busca constante pela cura, e a tão desejada melhora estaria na eliminação dos sintomas, de maneira que os procedimentos realizados eram sempre percebidos como insuficientes Até mesmo nos casos em que as equipes conseguiam o acompanhamento psiquiátrico ou psicoterapêutico almejado, as pessoas "não melhoravam". 
Nesse cenário, o NASF se apresentava à Estratégia de Saúde da Família ${ }^{1}$ (ESF) como uma espécie de promessa para a resolução dos problemas, pois os profissionais da Saúde Mental certamente saberiam como proceder - diziam as equipes de Saúde da Família. E, assim, tanto a população quanto os profissionais da ESF solicitavam ao NASF a prescrição de um procedimento, a apresentação de um caminho que pudesse acabar com o sofrimento da população atendida. Como responder a essas expectativas?

Nas primeiras semanas de trabalho, nós, profissionais do NASF, recebíamos algumas orientações. Deveríamos participar das reuniões de equipe, realizar um levantamento dos principais problemas de saúde da população atendida no território de abrangência, realizar atendimentos compartilhados e, sobretudo, discutir os casos com os profissionais da ESF. Havia uma orientação clara de que não deveríamos atender às famílias diretamente sem prévia discussão do caso, mas sim de forma compartilhada com os profissionais da ESF.

Éramos convocados a discutir os casos para poder realizar o matriciamento. Mas, discutir o quê, perguntavam os profissionais da ESF. E nós respondíamos: "precisamos colher as histórias de vida, compreender o processo de adoecimento para propor intervenções". Os agentes comunitários se incomodavam e mostravam-se preocupados em realizar uma série de perguntas sem saber o motivo, além de não saber o que poderiam oferecer.

Tratava-se de produzir a ampliação da clínica, ou seja, evitar que uma determinada abordagem fosse privilegiada em detrimento de outras, criando possibilidades para a construção de sínteses singulares a partir de diferentes matrizes de conhecimentos. Tal ampliação deveria partir do princípio de que os aspectos psíquicos e sociais relacionados às formas de viver das famílias fossem considerados para o estabelecimento do projeto assistencial em saúde.

Diante dessa perspectiva de ampliação, o que exatamente deveria ser visto ou ouvido pelos profissionais? Embora a inserção de diferentes categorias profissionais tivesse permitido a ampliação do olhar sobre o fenômeno do adoecimento mental, a forma de olhar parecia ser reduzida, pois mesmo buscando compreender os aspectos psíquicos,

\footnotetext{
${ }^{1}$ A Estratégia de Saúde da Família, na ocasião de sua implantação em 1994, foi denominada Programa de Saúde da Família. Somente a partir de 2006 é que ela assumiu a atual denominação, pois o termo "programa" aponta para uma atividade que tem início, desenvolvimento e término definidos, o que não condiz co m a proposta da ESF: consolidar-se como u ma política permanente, sem previsão para término.
} 
culturais e sociais envolvidos no processo de adoecimento, os olhares pareciam estar voltados às falhas, os distúrbios, para o que foge dos padrões de comportamento como sinal de uma patologia.

Ora, se olharmos para as questões sociais e psíquicas tal como para o corpo físico, a partir de suas funções padronizadas, não haverá, então, a efetivação da transformação do olhar, mas sim uma ampliação do mesmo olhar. Assim, aparentemente usávamos a mesma lente para compreender a situação de adoecimento mental - a clínica clássica -, o que direcionava o entendimento do cuidado necessário: a extinção das falhas, a cura da patologia.

Dentro dessa perspectiva, as ações no campo da Saúde Mental muitas vezes são pautadas na lógica do combate ao sofrimento por meio da prescrição de medicamentos para a restauração da saúde (CRUZ, 1997). Essas intervenções apresentam bons resultados em muitas situações, no entanto seus automatismos dificultam a estruturação de práticas fundamentadas em outros aspectos do adoecer que não apenas os sintomas.

Ainda com relação à busca pela construção de uma clínica ampliada, durante as reuniões de equipe tornou-se comum escutarmos que era necessário investigar o caso para depois passá-lo para o NASF, para que este pudesse propor a intervenção. Do que se trata essa investigação no campo da Saúde Mental? Por que ela se faz necessária? Que concepções de saúde e doença estavam por trás dessa necessidade de "investigar"? O que significava passar o caso?

Parecia haver entre os profissionais das equipes de Saúde da Família uma busca incessante por respostas. No entanto, não se tratava de qualquer resposta, mas sim daquelas fornecidas pelos especialistas. O que fazer com o adoecimento mental? O psiquiatra, o psicólogo e o terapeuta ocupacional devem saber, diziam.

Neste contexto, muitos profissionais da ESF vinham em nossa direção já com as guias de Referência e Contrarreferência preenchidas, como se não fosse preciso estabelecer a discussão sobre os casos, mas apenas o direcionamento rápido e não compartilhado para os especialistas. ${ }^{2}$

\footnotetext{
${ }^{2}$ Os protocolos de referência e contrarreferência eram utilizados de forma inadequada, pois as guias de referência devem ser usadas com o objetivo de encaminhar os casos atendidos para centros de especialidades, hospitais ou outras Unidades Básicas de Saúde, com u ma breve descrição dos atendimentos que o usuário recebeu na unidade que origina o encaminhamento. A contrarreferência é preenchida pelo serviço de saúde que recebeu o usuário, para que a unidade que orig inou o encaminhamento seja informada sobre quais ações de saúde estão sendo desenvolvidas junto ao usuário. Esse dispositivo auxilia na
} 
A ideia de passar o caso fazia-se constante. "Passar o caso", termo muito utilizado nas reuniões de matriciamento, poderia ser interpretado como uma atitude de falta de compromisso, de desresponsabilização e da necessidade de passar adiante um "problema". Mas, será? Não seria também uma forma de cuidar pautada na compreensão de que apenas quem detém o conhecimento mais especializado é apto para oferecer o cuidado necessário?

Nesse sentido, no cotidiano de trabalho junto ao NASF, era comum observar a dificuldade relacionada ao estabelecimento de trocas e de interações entre os diferentes saberes e experiências. Parecia haver uma soberania dos "especialismos", e disso decorriam práticas que fragmentavam o sujeito, como se cada profissional pudesse intervir em cada parte do corpo do indivíduo.

Era clara a dificuldade ligada ao estabelecimento de diálogos para a problematização de como desenvolver a interação entre as especialidades. Geralmente, durante as discussões de caso, elencavam-se várias possibilidades de intervenção. Contudo, as ações eram propostas em termos de categorias profissionais, o que gera va, em alguns casos, um excesso de intervenções desconectadas.

Frente a essas questões, tornava-se necessária a instituição de espaços que permitissem à ESF e ao NASF a formulação de discussões e a construção de novos sentidos para as práticas em saúde, atualizando modos de cuidar que fossem capazes de gerar rupturas com a lógica de encaminhamentos aos especialistas como única solução possível para a resolução dos problemas relacionados ao adoecimento mental.

A implantação do NASF como estratégia de fortalecimento da ESF apontava que a efetivação das metodologias de trabalho previstas por esse dispositivo - Apoio Matricial, Clínica Ampliada e Projeto Terapêutico Singular - não seria tarefa simples. Os profissionais das equipes de Saúde da Família colocavam suas claras demandas por atendimentos individualizados e especializados. Muitos diziam: "que bom ter um psicólogo só para a gente, não teremos mais que aguardar por atendimentos em serviços especializados", ou então, "o NASF é bom porque podemos encaminhar direto, não tem fila de espera".

O choque de expectativas ficava cada vez mais claro, e a sigla NASF passava a assumir outros sentidos para os profissionais da ESF, que diziam: "NASF? Ah, Nunca 
Atendo a Sua Família” ou “Não Atende, Só Fala”. E, assim, a preocupação em encontrar uma forma de construir a função de apoio e achar uma maneira de desenvolver um trabalho compartilhado era constante. Mas, como?

Nesse contexto de inquietações é que surgiram algumas das questões deste trabalho. Quais são as concepções de Saúde Mental apresentadas pelos profissionais da ESF e do NASF? Como se estabelecem as práticas nesse campo de intervenção? Como os profissionais da ESF e NASF articulam suas ações no cotidiano de trabalho?

A partir desses questionamentos, este trabalho tem como objetivo explicitar e discutir o contexto em que se desenvolvem a prática e a integração das ações em Saúde Mental realizadas pelos profissionais da ESF e NASF.

Para isso, optou-se pelo desenvolvimento de uma pesquisa qualitativa orientada pelo estudo de caso de uma equipe de Saúde da Família e uma equipe NASF atuantes em uma Unidade Básica de Saúde (UBS) localizada na região leste do município de São Paulo. ${ }^{3}$ Por se tratar de um estudo de caso sobre o funcionamento das equipes e sua prática, buscou-se estabelecer com os profissionais um diálogo articulado por meio da observação de reuniões de equipe, da análise de prontuários e da realização de grupos focais.

Esta dissertação será composta por uma apresentação das diretrizes do trabalho da ESF e do NASF, bem como pela discussão sobre a prática em Saúde Mental desenvolvida no âmbito da Atenção Básica em Saúde. Em seguida, serão apresentados o campo de pesquisa, os principais aspectos metodológicos, os dados encontrados a partir do diálogo com o campo, acompanhados pela discussão, e, por fim, as considerações sobre o estudo.

\footnotetext{
${ }^{3}$ Para garantir o sigilo dos profissionais da ESF e NASF, a Unidade Básica de Saúde não será identificada.
} 


\section{OBJETIVO}

É objetivo deste estudo discutir e produzir reflexões acerca do panorama em que se insere a prática e a integração das ações em Saúde Mental desenvolvidas pelos profissionais da Estratégia da Saúde da Família e do Núcleo de Apoio à Saúde da Família.

\subsection{Objetivos específicos}

- Identificar as concepções relacionadas à Saúde Mental e as principais ações e práticas desenvolvidas pelos profissionais nes se campo de intervenções;

- Identificar as barreiras e potencialidades apresentadas pelos profissionais para o desenvolvimento de ações integradas entre ESF e NASF, no que se refere às intervenções em Saúde Mental. 


\section{O PROCESSO DE TRABALHO NA ESTRATÉGiA de SAÚdE DA FAMÍLIA E NO NÚCLEO DE APOIO À SAÚDE DA FAMÍLIA}

\subsection{A Política Nacional de Atenção Básica à Saúde e a Estratégia de Saúde da Família}

A Política Nacional de Atenção Básica à Saúde, reformulada pelo Ministério da Saúde em 2006, afirma a Atenção Básica como nível primário de complexidade e a consolida como porta de entrada preferencial para o sistema de saúde, sendo responsável por coordenar o projeto assistencial nas redes de atenção do Sistema Único de Saúde (SUS) de acordo com as demandas de cuidado do indivíduo/família (BRASIL, 2006).

Esta política é regida dentro dos ordenamentos do SUS e por isso tem como diretrizes os princípios da universalidade, da integralidade e da equidade, apresentando como diretrizes organizativas a descentralização, regionalização e hierarquização. A descentralização refere-se às questões políticas e administrativas do sistema e relaciona-se às três esferas de governo: a municipal, a estadual e a nacional. A diretriz da regionalização do sistema estabelece que os serviços de saúde devem se responsabilizar pelos problemas de saúde da população de uma determinada área de abrangência, favorecendo a criação de vínculos de responsabilidade e compromisso com a população atendida. Já a hierarquização dos serviços está relacionada à ordenação do sistema em níveis de complexidade - primário, secundário e terciário (BRASIL, 2000).

Criada pelo Ministério da Saúde em 1994, a Estratégia de Saúde da Família é um dispositivo de atenção à saúde que se insere no nível de complexidade primário, ou seja, da Atenção Básica em Saúde. A ESF foi implantada com o objetivo de propiciar a reorganização do modelo de atenção em saúde. Para tanto, constitui-se como porta de entrada do sistema e apresenta como função a garantia da integralidade do cuidado, bem como a coordenação da assistência em saúde, tendo como objetos centrais o indivíduo e sua família, no contexto da comunidade (BRASIL, 2006).

Com o intuito de superar os modelos tradicionais de atenção em saúde, centrados na figura do médico e no pensamento organicista, a ESF apresenta uma lógica de trabalho pautada, entre outros fatores, no trabalho em equipe multiprofissional, na inserção da 
figura do agente comunitário de saúde (ACS), na adscrição ${ }^{4}$ de clientela e na participação social, priorizando as ações de promoção, proteção e recuperação da saúde.

Preconizando o trabalho multiprofissional, a equipe de Saúde da Família deve ser composta por médico, enfermeiro, auxiliar ou técnico de enfermagem e agentes comunitários. Quando ampliada, pode incluir também profissionais do campo da Saúde Bucal como, por exemplo, odontólogos e auxiliares ou técnicos em Saúde Bucal (BRASIL, 2012).

A composição da equipe busca instaurar um universo heterogêneo de conhecimentos e competências, viabilizando o desenvolvimento de ações comprometidas com a integração dos diferentes saberes para a construção partilhada e corresponsável de projetos assistenciais. Dentro dessa proposta, a criação de dispositivos democráticos para discussão e para tomada de decisões relacionadas à gestão do cuidado ganha destaque como possibilidade de produção de autonomia dos profissionais e da população para o enfrentamento do processo de adoecimento (SANT'ANNA; HENNINGTON, 2011).

A inserção do agente comunitário de saúde na equipe é o grande diferencial desse modelo de atenção, pois estes profissionais são, necessariamente, pessoas que moram no território de abrangência de atendimento da Unidade Básica de Saúde (UBS). O ACS é, portanto, aquele que apresenta melhores condições para reconhecer as principais fragilidades e problemas de saúde da população, bem como para identificar os recursos disponíveis e as potencialidades do território.

O ACS é figura central no processo de adscrição da clientela e na busca pelo estabelecimento de relações de vínculo e responsabilização entre o serviço de saúde e a população atendida. O vínculo, compreendido aqui como a construção de relações de afetividade e confiança entre o usuário e o profissional, é o elemento que viabiliza e potencializa o aprofundamento das relações de corresponsabilização entre os profissionais e os usuários na estruturação do cuidado (BRASIL, 2012).

É por meio da adscrição da clientela que os profissionais da ESF devem iniciar o diálogo com a população para o estabelecimento do diagnóstico situacional do território, o que significa que devem ser considerados não apenas os aspectos relacionados aos

\footnotetext{
4 Adscrever a clientela significa definir um território geográfico de abrangência que estará sob a responsabilidade dos cuidados de uma determinada Unidade Básica de Saúde. A adscrição se dá por meio do cadastro das famílias.
} 
sintomas clínicos, mas também os aspectos culturais, sociais e psicológicos envolvidos no processo de adoecimento.

A participação da comunidade no processo de reconhecimento das principais vulnerabilidades relacionadas ao adoecer e na organização de propostas de enfrentamento dos problemas de saúde, aliada ao trabalho multiprofissional, confere à ESF a possibilidade de operar uma inversão da lógica de atenção à saúde. Esse arranjo organizacional do serviço de saúde viabiliza o deslocamento do processo de trabalho pautado em procedimentos profissionais para um processo centrado nas demandas formuladas pelo usuário e pela família.

Essa lógica favorece que as intervenções propostas sejam formuladas a partir da identificação das necessidades da população e não o contrário, como nos modelos tradicionais, em que há uma oferta de serviços e ações e as pessoas devem adequar-se a eles. Contudo, essa proposta de ordenamento exige que se instaure a transformação dos modos de produzir as ações de cuidado, o que pede aos profissionais maior capacidade de análise, intervenção e autonomia para a formulação de práticas comprometidas com as demandas do território em que se atua.

A ESF busca, assim, romper com a lógica de organização dos serviços de saúde que estabelece a divisão das intervenções a partir de departamentos estruturados pela lógica das especialidades médicas. Como apontam Campos e Domitti (2007), esse tipo de organização apresenta baixo grau de comunicação entre os profissionais, de coordenação das ações e de integração entre os distintos saberes envolvidos na articulação de um projeto assistencial em saúde, gerando a fragmentação do trabalho e do cuidado. Tais questões se colocam como obstáculo para a integralidade do cuidado, para a prática da clínica ampliada e para o trabalho interdisciplinar.

Com o intuito de superar a fragmentação das ações, a ESF busca uma organização do trabalho não por departamentos de especialidades, mas sim pela estruturação de unidades de produção e equipes de referência em que diferentes categorias de profissionais se organizam em torno de um objetivo comum (CAMPOS, 1998).

Segundo Campos e Domitti (2007, p. 400), "a equipe de referência é um rearranjo organizacional que busca deslocar o poder das profissões e corporações de especialistas, reforçando o poder de gestão da equipe interdisciplinar”. Para isso, preconiza a criação de espaços de discussão entre os profissionais para o estabelecimento do diagnóstico das necessidades de saúde da população, das divisões de papéis e responsabilidades e de planos 
e modelos de atenção mais adequados às necessidades e aos recursos disponíveis, para, por fim, elaborarem as metas a serem atingidas.

Assim, todo o processo de construção dos planos de atenção, de organização do trabalho e de tomadas de decisão deve contar com a participação democrática da população atendida e dos profissionais de saúde.

Nessa lógica de trabalho em saúde, a ESF preconiza a interdisciplinaridade, que se define pelas possibilidades de trocas de conhecimentos entre especialistas e pela integração dos saberes produzidos em cada disciplina no estabelecimento de um projeto assistencial. A interdisciplinaridade, dessa forma, pressupõe a negação e superação das fronteiras disciplinares (JAPIASSU, 1976). Isto é, um empreendimento em que são incorporados os saberes, técnicas, instrumentos ou metodologia de trabalho de diferentes disciplinas a fim de integrá-los para a realização de uma atividade coletiva que apresenta um objetivo comum.

Ainda, o modelo de trabalho da ESF valoriza que se instaurem processos de democratização e participação da gestão dos serviços, dos profissionais de saúde, da família atendida e da comunidade para a estruturação do projeto assistencial em saúde. As equipes de referência, ao proporem intervenções, devem considerar as diretrizes apresentadas pelos órgãos ministeriais, estaduais e municipais responsáveis pela saúde, articulando-as às necessidades e interesses apresentados pela população atendida para a proposição de ações e enfrentamento dos problemas de saúde (CAMPOS, 1998; CAMPOS; DOMITTI, 2007).

Após aproximadamente 18 anos da implantação da ESF, alguns pesquisadores do campo da saúde têm produzido análises e reflexões acerca da implantação desse dispositivo de atenção. Segundo Scarcelli e Junqueira (2011), a ampliação da Atenção Básica tem se dado por meio do aumento do número de equipes de Saúde da Família, ou seja, do crescimento no número de famílias atendidas. Trata-se, assim, de uma valorização quantitativa, sem grandes ações que garantam a qualidade da formação profissional e enfrentem a insuficiência de educações permanentes, a baixa valorização salarial dos profissionais e a precarização do financiamento e da gestão de pessoal, o que vem contribuindo para a baixa qualidade dos atendimentos e dificultando a implantação efetiva dos princípios do SUS.

Apesar da implantação da ESF ter apresentado importantes avanços no que se refere à reestruturação do sistema de saúde, à integralidade do cuidado e ao trabalho em 
equipe, Franco e Merhy (2003) apontam que a efetivação da transformação do modelo de atenção exige que se estabeleça a reorganização de processos de trabalho, reorganização esta que privilegie e valorize os aspectos relacionais entre o técnico e o usuário presentes nas práticas de cuidado em saúde. Haveria aí, entretanto, uma tensão.

Ora, a ESF pode ser entendida como um dispositivo em que se reconhece na mudança do modelo assistencial em saúde a possibilidade de transformações nas formas de organização do processo de trabalho a partir das equipes multiprofissionais de referência. Contudo, apesar de a ESF localizar o problema nos processos de trabalho, essa estratégia não consegue decifrá-lo, não consegue dizer do que se trata, levando os profissionais a serem conduzidos "pela feroz dinâmica do trabalho medicocentrado, e por não saber inclusive por limitação ideológica de seus operadores -, acaba operando centralmente na produção de procedimentos e não na produção do cuidado e da cura" (FRANCO; MERHY, 2003, p. 105).

Afinal, como lembram Merhy, Feuerwerker e Cerqueira (2010), a transformação efetiva dos modelos de atenção em saúde exige que as ações de cuidado sejam construídas em um território de encontro entre o trabalhador de saúde e seus saberes e as necessidades e saberes dos usuários, já que "é nesse território que se produzem os encontros e a possibilidade de uma construção negociada afetivamente, interessadamente, pois aí é que se faz valer a autonomia dos usuários e que se torna possível fabricar o trabalho da equipe de saúde" (p. 73).

Nesse sentido, a ESF parece buscar uma transformação marcada pela instauração de um trabalho vivo, que se dá nas e pelas relações, seja entre trabalhadores, seja com usuários. Uma transformação, como apontam Franco e Merhy (2003), que exige uma nova consciência sanitária e a adesão desses trabalhadores ao novo projeto.

Diante de toda a complexidade de intervenções exigidas aos profissionais da ESF, para apoiar e ampliar a resolubilidade desse modelo de atenção, o Ministério da Saúde criou, em 2008, o Núcleo de Apoio à Saúde da Família (BRASIL, 2008).

\subsection{O Núcleo de Apoio à Saúde da Família}

O NASF é um dispositivo criado pelo Ministério da Saúde a partir da observação de experiências de utilização dos conceitos de Equipes de Referência e Apoio Matricial. É uma proposta que visa oferecer apoio à ESF para a superação da fragmentação das 
intervenções e garantia da integralidade do cuidado pelos profissionais e serviços frente à assistência da população atendida. Para isso, preconiza a reorganização do trabalho e das possibilidades de transformações relacionadas às relações de poder e às possibilidades de democratização na tomada de decisões a respeito dos projetos assistenciais (CUNHA; CAMPOS, 2011).

A compreensão da função de apoio exercida na proposta do Apoio Matricial decorre dos conceitos de cada um de seus termos. Campos e Domitti (2007) esclarecem que o termo "matriz" assume vários sentidos; um deles é matriz como lugar onde há criação e geração de determinados elementos; outro está relacionado ao campo da matemática em que os números, em uma matriz, guardam relações entre si, permitindo análises verticais, horizontais e transversais. Já o termo "apoio" indica uma maneira de agir em saúde pautada no estabelecimento de uma relação não autoritária entre os diferentes profissionais, na lógica de que a relação entre sujeitos com saberes, valores e funções específicas possam interagir de maneira dialógica.

Os próprios termos já indicam, então, que o Apoio Matricial, metodologia que opera transversalidades e relações interdependentes, tem como diretriz o trabalho interdisciplinar, sendo elemento chave para a ampliação e qualificação da as sistência.

O matriciamento apresenta duas dimensões, uma relacionada ao suporte assistencial e outra ao apoio técnico-pedagógico. O elemento assistencial é aquele relacionado à produção de ações e intervenções clínicas diretamente com usuários e comunidade, e as ações técnico-pedagógicas visam à produção de apoio às equipes de Saúde da Família (CAMPOS, 1999).

Segundo Campos e Domitti (2007), o Apoio Matricial objetiva assegurar retaguarda especializada às equipes de Saúde da Família, de forma a ampliar possibilidades de intervenções e aumentar a capacidade de resolver problemas em saúde. Para isso, priorizase a articulação entre as equipes, que se dá em três planos principais: atendimentos e intervenções conjuntas; orientações e capacitação durante reuniões e discussões de caso; e atualização contínua da equipe quando houver atendimentos que exijam atenção específica de determinado profissional. Ainda, há a orientação de que as ações sejam acordadas entre os profissionais da ESF e NASF durante as reuniões de equipe e que a frequência desses encontros seja determinada a partir de negociações entre as equipes, de acordo com a complexidade de cada caso (BRASIL, 2009b). 
Vê-se aí que se objetiva a instauração de um novo processo de trabalho pautado na cogestão. Assim, com o intuito de fortalecer a ESF na superação dos modelos convencionais de assistência à saúde, que visam à assistência curativa, especializada e fragmentada, o NASF busca a corresponsabilização e a gestão integrada do cuidado em saúde junto a ESF.

Para isso, conforme Campos (1998), utiliza-se estratégias como a construção de projetos terapêuticos que envolvam os usuários e a equipe de Saúde da Família, bem como o desenvolvimento de ações e atendimentos compartilhados comprometidos com a singularidade dos sujeitos assistidos, no qual o matriciador deve ser o agente promotor da instituição de processos de reflexão e crítica entre os profissionais da equipe.

A partir desse objetivo - e princípio de trabalho -, a Portaria GM n ${ }^{\circ} 154$, de 24 de janeiro de 2008, estabelece que o NASF seja composto de equipe multiprofissional e, para evitar a fragmentação do sujeito atendido e garantir a interdisciplinaridade, suas ações junto à ESF não são divididas em termos de categoria profissional, mas sim por áreas estratégicas. São elas: atividade física e práticas corporais; práticas integrativas e complementares; reabilitação; alimentação e nutrição; Saúde Mental; Serviço Social; saúde da criança, do adolescente e do jovem; saúde da mulher; e assistência farmacêutica.

A atuação em tais áreas de intervenção deve ser necessariamente garantida pelo NASF. Contudo, a organização das equipes pode se dar a partir de diferentes configurações, já que as categorias e número de profissionais podem variar de acordo com as demandas locais. Estabelece-se também que, de acordo com o porte do município determinado por sua densidade populacional - há as modalidades NASF 1, 2 e 3 (BRASIL, 2012).

A equipe de NASF 1 deve ser composta por, no mínimo, profissionais de cinco categorias de nível superior, entre elas: fisioterapeuta, fonoaudiólogo, psicólogo, terapeuta ocupacional, nutricionista, assistente social, farmacêutico, educador físico, médico acupunturista, pediatra, psiquiatra e ginecologista, constituindo-se como referência para oito a vinte equipes de Saúde da Família.

O NASF 2 deve ser composto por três categorias profissionais, incluindo: fisioterapeuta, fonoaudiólogo, psicólogo, terapeuta ocupacional, nutricionista, assistente social, educador físico e constituir-se referência para, no mínimo, três equipes de Saúde da Família. Os NASF 2 deverão ser implantados em municípios de pequeno porte, com uma densidade populacional abaixo de dez habitantes por quilômetro quadrado. 
Em dezembro de 2012 foi publicada a Portaria GM 3.124 do Ministério da Saúde, que redefine os parâmetros de vinculação dos Núcleos de Apoio à Saúde da Família (NASF) modalidades 1 e 2 às equipes Saúde da Família e cria a modalidade NASF 3. A nova portaria estabelece a redução do número de equipes de ESF às quais cada modalidade de NASF deverá se vincular. Assim, cada NASF 1 deve estar vinculado a no mínimo cinco e a no máximo nove equipes Saúde da Família, e cada NASF 2 deve estar vinculado a no mínimo três e no máximo quatro. A criação do NASF 3, equipe que deverá ser referência para no mínimo uma e no máximo duas equipes Saúde da Família, responde à demanda de ampliação do acesso ao NASF para municípios que possuem poucas equipes de Saúde da Família.

A definição dos profissionais que irão compor cada tipo de equipe NASF é de responsabilidade do gestor municipal, que deve seguir critérios como a prioridade identificada a partir das necessidades locais, do perfil epidemiológico e social e da disponibilidade de profissionais de cada uma das diferentes ocupações. No entanto, em decorrência da magnitude epidemiológica dos transtornos mentais, é feita a recomendação de que cada equipe contemple ao menos um profissional da área de atuação em Saúde Mental.

Ainda segundo as diretrizes do Ministério da Saúde, a avaliação do trabalho dos profissionais do NASF, bem como o estabelecimento de metas, deve estar articulada a dois focos do trabalho da equipe: a atenção à população e o trabalho com a equipe de Saúde da Família. Dessa forma, é necessário o estabelecimento de indicadores de resultado para a população, mas também indicadores de resultado da sua ação na equipe (BRASIL, 2009b).

Para contemplar pragmaticamente suas diretrizes e ações, o NASF utiliza-se, além do Apoio Matricial, das seguintes ferramentas tecnológicas: a Pactuação do Apoio, a Clínica Ampliada, o Projeto Terapêutico Singular (PTS) e o Projeto de Saúde no Território (PST).

Para a Pactuação do Apoio, os gestores, equipes de Saúde da Família e o Conselho Local de Saúde devem reunir-se para estabelecer o diagnóstico situacional e para determinar os objetivos e metas a serem alcançados (BRASIL, 2009b).

Procurando sustentar a diretriz de integralidade proposta pelo SUS, a prática da Clínica Ampliada visa reconhecer aspectos do processo saúde/doença que envolvem, além dos aspectos biológicos, aspectos singulares do proces so de adoecimento do indivíduo e do coletivo. Essa concepção permite a ampliação das possibilidades de resolubilidade, 
fortalecendo o cuidado integral do sujeito e da família no contexto em que estão inseridos (CUNHA, 2005).

Este tipo de clínica, ao propor um conceito de saúde ampliado, tem como enfoque a construção de autonomia da população atendida para o enfrentamento de situações de vulnerabilidade. Além disso, apresenta como proposta estimular que os trabalhadores reflitam sobre as questões culturais e sociais e atuem na perspectiva de uma intervenção humanizada, crítica e reflexiva, voltada para a produção integral de saúde (ALVES; AERTS, 2011).

Faz-se então necessário a organização de projetos assistenciais condizentes com a ampliação das intervenções. Com vistas a organizar essas ações, o Projeto Terapêutico Singular (PTS) apresenta-se como estratégia para a operacionalização de condutas terapêuticas articuladas, tendo como elemento central a singularidade e podendo ser aplicado ao indivíduo, famílias ou grupos.

Como aponta Oliveira (2008), esse projeto deve ser resultado da discussão coletiva da equipe interdisciplinar e do planejamento realizado durante reuniões de equipe e atendimentos compartilhados junto ao sujeito/família. Estes devem ter autonomia e corresponsabilidade nessa construção.

O PTS, composto por diagnóstico, definição de metas, divisão de responsabilidades e reavaliação, é desenvolvido em casos mais complexos e apresenta-se como variação da discussão de caso clínico, com o objetivo de garantir intervenções integradas da equipe, bem como valorizar aspectos do processo de adoecimento que extrapolam as questões biológicas, o diagnóstico psiquiátrico e a intervenção medicamentosa (OLIVEIRA, 2008).

Merhy (2000, p. 112) problematiza o desenvolvimento do projeto assistencial esclarecendo que:

as intervenções em saúde são permeadas por construções de projetos terapêuticos tensos, pois cobra-se dele [médico ou profissional de saúde], e também de todo o seu saber fazer, tanto o operar a produção de uma dimensão própria do cuidar dada pelos processos relacionais e leves do trabalho em saúde, nas suas relações próprias com os saberes tecnológicos estruturados, da valise das tecnologias leve-duras, quanto a um outro específico do próprio ato médico, vinculado a um certo recorte do saber disciplinar, expresso por uma ordem 'profissional', composto centralmente nas relações entre aqueles saberes tecnológicos com a valise das 
tecnologias duras, focando a produção de procedimentos centrada no médico.

Como complemento ao PTS, o trabalho do NASF pauta-se também na estraté gia de ampliação das intervenções a coletivos, e para isso instaura-se o Projeto de Saúde no Território (PST).

Por intermédio da estruturação do PST, pretende-se a criação de estratégias conjuntas entre os profissionais das equipes ESF e NASF para a articulação de ações que visam a produção de saúde de um determinado território. O foco do PST é a articulação de serviços de saúde com outros serviços ou políticas sociais, com o objetivo de promover a qualidade de vida, autonomia e cidadania da população atendida (BRASIL, 2009b).

A construção do PST tem início a partir da identificação de problemas e da vulnerabilidade de uma determinada população. Esse diagnóstico pode ser estabelecido por meio da discussão de um caso clínico determinado, como, por exemplo, um adolescente com histórico de abuso de álcool e drogas; ou a partir da análise de uma determinada situação vivenciada pela comunidade, como alta incidência de violência doméstica (BRASIL, 2009b).

A partir do reconhecimento das vulnerabilidades e potencialidades do território, elabora-se o diagnóstico que servirá como guia para o desenvolvimento das ações. Essa forma de organizar as ações está fortemente relacionada aos objetivos de produção de intervenções de promoção de saúde e prevenção do adoecimento preconizadas pela ESF.

A Pactuação do Apoio, o Apoio Matricial, a Clínica Ampliada, o Projeto Terapêutico Singular e o Projeto de Saúde no Território são, como apresentado acima, ferramentas de apoio à ESF no que se refere às possibilidades de estruturação de espaços para a articulação entre os diferentes saberes, de construção de uma cultura organizacional mais democrática e para a reorganização de um modelo de trabalho pautado na cogestão.

Embora o NASF seja um dispositivo criado recentemente, alguns estudos foram desenvolvidos sobre as ferramentas que compõem sua proposta de intervenção. Inúmeros

\footnotetext{
${ }^{5}$ Merhy (2000) estabelece que o trabalho em saúde é composto por uma combinação de diferentes tipos de tecnologias - as tecnologias duras, as leve-duras e as leves. Para o autor, as tecnologias duras são aquelas relacionadas aos aparatos tecnológicos como as máquinas e equipamentos e as normas e estruturas organizacionais. As tecnologias leve-duras possuem uma parte estruturada representada pelos conhecimentos da clínica médica, epidemiologia, entre outros, e parte leve relacionada ao modo de agir de cada profissional diante das demandas e das ferramentas de trabalho de que dispõem. As tecnologias leves são aquelas que dizem respeito aos as pectos relacionais entre os profissionais e entre estes e os usuários dos serviços, ou seja, o vínculo, acolhimento, gestão do processo de trabalho, entre outros.
} 
desafios são apontados para a implantação desse dispositivo, como o excesso de demanda por atendimentos individualizados e especializados, a carência de recursos e serviços especializados de retaguarda, a fragilidade de experiências e da cultura do trabalho interdisciplinar e a imprecisão do documento norteador do NASF quanto à execução do trabalho.

Andrade et al. (2012), ao estudarem o processo de implantação do NASF no interior de Santa Catarina, afirmam que a inserção desse dispositivo se dá na tensão entre potencialidades e fragilidades. Percebeu-se a melhora da definição de prioridades a serem referenciadas para outros níveis de complexidade de atenção em saúde e melhora na realização de planejamento de atividades e nas condições de realização do trabalho em equipe. Por outro lado, há fragilidades relacionadas à carência de educação permanente, à baixa adesão à metodologia de trabalho proposta pelo NASF e, por fim, à prevalência da fragmentação das ações e a desarticulação dos profissionais no que se refere à elaboração de projetos terapêuticos.

Em relação à interd isciplinaridade e ao trabalho em equipe, a falta de tempo devido à demanda por atendimentos e a fragilidade de comprometimento de alguns profissionais, sobretudo de médicos, são aspectos do trabalho identificados como responsáveis pelo desenvolvimento de ações pouco conectadas entre si. (S AMPAIO et al., 2012).

Ainda segundo Sampaio et al (2012), os profissionais da ESF e do próprio NASF não possuem clareza sobre a proposta de metodologia de trabalho apresentada por esse dispositivo. A fragilidade da compreensão sobre o papel a ser exercido pelos profissionais do NASF, aliada a problemas estruturais, como a escassez de serviços especializados, induz a uma utilização arbitrária do apoio oferecido.

Essa situação traz implicações para a prática, pois com frequência os profissionais do NASF são vistos como referência e não como equipe de suporte, o que gera uma expectativa de que possam atender à demanda dentro de uma lógica de encaminhamentos e não de acordo com a lógica de realização de atendimentos compartilhados e da corresposabilização. Percebem-se, assim, dissonâncias entre o discurso e a prática em que a interdisciplinaridade e corresponsabilização ainda são muito incipientes (CUNHA; CAMPOS, 2011).

Lancman e Barros (2011), ao discutirem as possíveis contradições e desafios enfrentados na implantação do NASF, avaliam que o documento norteador para sua implantação é impreciso, gerando uma série de problemas para a estruturação do processo 
de trabalho entre as equipes. Uma primeira dificuldade estaria relacionada à estruturação de formas de organização do trabalho entre a ESF e NASF, formas geradoras de desarticulação das ações, quando a proposta seria o compartilhamento. Enquanto o NASF preconiza e define agendas e metas que priorizam o matriciamento, as reuniões e as consultas, visitas domiciliares e grupos conjuntos, os profissionais da ESF têm suas metas pautadas nos números elevados de atendimentos individuais. Percebe-se, assim, um desencontro de partida, já presente na definição dos focos de trabalho, permitindo pouca articulação entre eles.

As autoras afirmam que, em um campo de disputas entre diferentes modelos de atenção, a carência de diretrizes sobre como operar aquilo que propõe o NASF gerou a implantação de diferentes propostas de trabalho, algumas delas fortemente ligadas ao modelo de atenção médico-assistencial. Somente após a publicação do Caderno de Atenção Básica $n^{o} 27$ (BRASIL, 2009b) - o que significa um lapso temporal de pouco mais de um ano -, é que o modelo de cogestão passou a ser mais conhecido, estruturando o trabalho de algumas equipes.

Outra dificuldade se relaciona ao excesso de demandas e carência de recursos. O elevado número de pessoas adoecidas e a demanda por serviços especializados geram pressão sobre os profissionais do NASF que são, com frequência, solicitados a realizarem atendimentos ambulatoriais, especializados e individualizados. Quer dizer, uma proposta de matriciamento torna-se muitas vezes pouco possível quando condições concretas são marcadas pela precarização de formas de vida e de saúde, requerendo outras atenções.

A mescla entre a lógica do público e do privado gerada pela forte presença das Organizações Sociais de Saúde na implantação e gestão dos NASF é vista também como uma importante dificuldade para a implantação do NASF. Esse tipo de gestão gera a precarização de contrato de profissionais e compromete, em alguns casos, a implantação e consolidação dessa política de saúde. ${ }^{6}$

Por fim, outra dificuldade se refere à fragilidade de uma cultura de trabalho interdisciplinar e à pouca experiência acumulada nesse tipo de proposta. Ambas, aliadas à precária prescrição do trabalho, favorecem que cada profissional ou categoria de profissionais desenvolvam ações especializadas, gerando a fragmentação do cuidado.

\footnotetext{
${ }^{6}$ No município de São Paulo há u ma forte presença de Organizações Sociais de Saúde (OSS) na implantação e gestão dos Núcleos de Apoio à Saúde da Família.
} 
Assim, a proposta de romper com "especialismos" - princípio fundante do NASF - tornase pouco exequível, sendo marcada pela repetição daquilo que se pretendia superar.

Diante da apresentação das diretrizes de trabalho da ESF e do NASF e da discussão proporcionada por análises e estudos sobre a implantação do NASF, realizaremos uma caracterização sobre algumas condições de saúde mental no âmbito da Atenção Básica, seguida pela discussão de alguns aspectos da prática nesse campo de intervenções.

\subsection{A Saúde Mental na Estratégia de Saúde da Família e o Núcleo de Apoio à Saúde da Família}

A Saúde Mental, campo de conhecimentos e práticas, teve o início de sua constituição no contexto de redemocratização do país, a partir do movimento de Reforma Psiquiátrica.

Contando com a participação de diversos atores sociais, tais como os usuários, familiares, trabalhadores de Saúde Mental, representantes de universidades, entre outros, a Reforma Psiquiátrica caracterizou-se como um movimento político, social e ideológico. Buscava não apenas a superação, mas a substituição das práticas de atenção ao doente mental fundamentados no hospital psiquiátrico, na medicalização e na exclusão (MIELKE; OLCHOWSKY, 2010).

O modelo de atenção psiquiátrico propunha, até então, ações pautadas no estabelecimento de diagnóstico baseado no funcionamento dos órgãos e do corpo anatômico. Esse tipo de clínica, nascida no século XVIII, tem sido hegemônica no que se refere aos cuidados oferecidos ao doente mental. Nela, o corpo é tomado como único objeto de cuidado e, para isso, deve ser examinado minuciosamente a fim de que se encontre algum problema em seu funcionamento que justifique o conjunto de sintomas que caracterizam uma patologia. Vale lembrar que a definição das características a serem examinadas é formulada a partir de um determinado padrão de normalidade (FRANCO; GALAVOTE, 2010).

Neste modelo clínico não apenas o indivíduo é tomado como objeto, mas também a família. Esta deve ser atentamente examinada na busca de falhas, faltas, disfunções e comportamentos que justifiquem o adoecimento de um de seus membros.

A clínica psiquiátrica clássica apresenta algumas fragilidades e limitações, como a existência de pacientes que não respondem ao tratamento, a baixa adesão aos cuidados 
oferecidos e aos encaminhamentos, a dependência dos usuários em relação aos medicamentos e aos atendimentos especializados e a insatisfação dos profissionais no que se refere às intervenções (CARVALHO; CUNHA, 2006).

Com o intuito de superar tais dificuldades, rompendo com a objetivação da loucura e do louco e com o processo de patologização dos comportamentos e sofrimentos psíquicos, as práticas instituídas no campo da Saúde Mental pretendem o estabelecimento de ações que visam a construção de um lugar social para a diferença e para a loucura por meio da construção da autonomia, da cidadania e da inclusão social (AMARANTE, 1999).

Procura-se, então, nesse campo de intervenções, a instauração de ações capazes de superar os automatismos gerados no campo da psiquiatria, criando possibilidades de vida que não sejam aquelas revestidas pela tutela promovida pelas práticas e instituições psiquiátricas, mas que viabilizem a participação das pessoas na gerência de sua própria vida. Trata-se, como apontam Scarcelli e Alencar (2009), de tentar produzir uma nova cultura sobre o adoecimento mental, uma cultura engendrada por meio da composição de olhares que permitam que o cuidado em saúde se organize a partir do contexto de vida das pessoas, de sua singularidade e potencialidades, buscando preservar as possibilidades de circulação e de construção de projetos de vida.

A partir dessas noções de cuidado em Saúde Mental e apoiada pela Lei Federal 10.216, que dispõe sobre a proteção e os direitos das pessoas com transtornos mentais, redirecionando o modelo assistencial neste âmbito, a Política Nacional de Saúde Mental determina que se estabeleça um processo de desinstitucionalização das pessoas com transtornos mentais, o que significa a redução gradual de leitos em hospitais psiquiátricos e das longas internações, além da criação e implantação de uma rede diversificada de serviços e dispositivos de atenção à saúde de base comunitária.

A rede de Saúde Mental deve ser composta por diversas ações e serviços de saúde mental: Atenção Básica, Centros de Atenção Psicossocial (CAPS), ambulatórios, residências terapêuticas, leitos de atenção integral em Saúde Mental em hospital geral ou em CAPS III, ${ }^{7}$ Programa de Volta para Casa, cooperativas de trabalho e geração de renda, centros de convivência e cultura, entre outros (BRASIL, 2009).

\footnotetext{
${ }^{7}$ A Portaria 336 de 19 de fevereiro de 2002 estabelece que os Centros de Atenção Psicossocial podem constituir-se nas seguintes modalidades de serviços: CAPS I, II e III, definidos a partir da ordem crescente de complexidade e pela abrangência populacional. O que diferencia cada modalidade de CAPS é a composição da equipe, o nú mero de pessoas atendidas e o horário de funcionamento. O CAPS I deve ser composto por equipe mínima de: um médico; um enfermeiro; três profissionais de nível superior entre as
} 
A mudança do modelo de atenção em Saúde Mental e a ampliação e diversificação da rede de cuidados tem como principal objetivo:

\begin{abstract}
a ampliação e a qualificação do cuidado às pessoas com transtornos mentais nos serviços, com base no território. No novo modelo, a atenção hospitalar deixa de ser o centro, como era antes, tornando-se complementar. Trata-se de mudança fundamental na concepção e na forma de como se deve dar o cuidado: o mais próximo da rede familiar, social e cultural do paciente, para que seja possível a reapropriação de sua história de vida e de seu processo de saúde/adoecimento. Aliada a isso, adota-se a concepção de que a produção de saúde é também produção de sujeitos. Os saberes e práticas não somente técnicos devem se articular à construção de um processo de valorização da subjetividade, no qual os serviços de saúde possam se tornar mais acolhedores, com possibilidades de criação de vínculos. (BRASIL, 2009b)
\end{abstract}

Nessa perspectiva há princípios comuns de atuação propostos pela política de Saúde Mental e pelas equipes de Saúde da Família: ambas preconizam a atuação a partir do contexto familiar e territorial.

A Estratégia de Saúde da Família, por ser um dispositivo que atua de maneira muito próxima às famílias do território de abrangência - proximidade viabilizada pelos atendimentos periódicos e pela realização de visitas domiciliares mensais -, tem condições de desenvolver o diagnóstico e intervenções precoces (BRASIL, 2009).

Os profissionais das equipes de Saúde da Família, por manterem relação com o território, deparam-se cotidianamente com questões que apresentam enraizamentos nas estruturas sociais, econômicas e políticas em que está imersa a população atendida. Dessa forma, apresentam como peculiaridade a possibilidade de estabelecer o reconhecimento dos determinantes sociais e dos fenômenos geradores e mantenedores de situações de

categorias profissionais de psicólogo, assistente social, terapeuta ocupacional, pedagogo ou outro profissional necessário ao projeto terapêutico; quatro profissionais de nível médio - técnico e/ou au xiliar de enfermagem, técnico administrativo, técnico educacional e artesão -, devendo atender uma população com população entre 20 e 70 mil habitantes e funcionar das 8 às 18 horas durante os cinco dias úteis da semana. O CAPS II tem o mesmo horário de funcionamento do CAPS I e u ma equipe com a mes ma composição de categorias profissionais, porém em número maior, sendo responsáveis por atender uma população de 70 a 200 mil habitantes. O CAPS III deve ser referência para uma população acima de 200 mil habitantes e possui a maior equipe das três modalidades, tendo como principal diferencial funcionar pelo período de 24 horas, incluindo feriados e finais de semana, o que possibilita a oferta de cuidados noturnos e até mesmo o acolhimento da pessoa com transtorno mental por breves períodos de internação. A permanência de um mes mo paciente no acolhimento noturno fica limitada a sete dias corridos ou dez dias intercalados em um período de trinta dias. Existem ainda as modalidades de CAPS voltados para a atenção a crianças e adolescentes (CAPS Infantil) e o serviço de atenção a pessoas com histórico de uso e dependência de substâncias psicoativas (CAPS Álcoole outras drogas) (BRASIL, 2002). 
intenso sofrimento psíquico e adoecimento da população, estruturando junto à comunidade diagnósticos situacionais e planos de intervenções.

Essa peculiaridade é dada, entre outros fatores, pela inclusão do agente comunitário de saúde na equipe de Saúde da Família. Esse profissional, morador da comunidade em que atua, é peça chave para o estabelecimento de diagnósticos mais coerentes com as possibilidades de intervenção junto à comunidade e para a construção de vínculos de compromisso com essa comunidade.

A ESF apresenta ainda, como apontam Tanaka e Ribeiro (2009), potencial para desenvolver, principalmente, dois tipos de ações no campo da Saúde Mental. A primeira se relaciona às condições de detectar precocemente queixas e sinais relativos ao sofrimento psíquico e acolher por meio de escuta qualificada esse tipo de problemática. A segunda ação consiste na oferta de tratamento na própria atenção básica ou no encaminhamento para serviços especializados, quando detectada necessidade desse tipo de intervenção.

Além disso, as equipes de Saúde da Família, ao preconizarem que os cuidados possam ser oferecidos em domicílio, apresentam condições de desenvolver intervenções junto às famílias que vivenciam situações de isolamento domiciliar, quando o usuário encontra barreiras para acessar os serviços de saúde. Assim, potencializam-se os recursos disponíveis e facilita-se o acesso ao cuidado.

Diante desse cenário, a inclusão de ações de saúde mental na Atenção Básica deve ser prioridade na organização das redes de cuidado. Para o melhor manejo das situações que envolvem o adoecimento, propõe-se um trabalho compartilhado de suporte às equipes de Saúde da Família por meio do Apoio Matricial em saúde mental realizado pelos profissionais dos Núcleos de Apoio à Saúde da Família.

Para orientar as responsabilidades conjuntas e a integração das intervenções entre a ESF e o NASF, o Ministério da Saúde recomenda a estruturação de condições de trabalho interdisciplinar e intersetorial, o que viabiliza o rompimento com a lógica de encaminhamentos e favorece a corresponsabilização dos profissionais e dos serviços especializados de referência em Saúde Mental na coordenação e continuidade do cuidado (BRASIL, 2009).

Contudo, apesar de haver diretrizes sobre o trabalho da ESF e NASF no campo da Saúde Mental, Nunes et al. (2007) apontam que há algumas dissonâncias e convergências entre a prática proposta pela ESF e a política em Saúde Mental pautada nas diretrizes da Reforma Psiquiátrica. No que se referem às convergências, evidencia-se a proposição de 
um serviço de cuidados com base territorial, o que permite maior condição de desenvolvimento de intervenções pautadas em aspectos psicossociais do adoecimento e do manejo das intervenções. Entretanto, identificam a não inclusão efetiva das ações de cuidado em Saúde Mental na ESF ou a sua escassez, devido ao pouco conhecimento dos princípios da Reforma Psiquiátrica, à falta de capacitação dos profissionais para atuarem neste campo, à não identificação dos problemas em Saúde Mental como prioridades de intervenção, à escassez de recursos e condições para atendimento e, por fim, à ausência de uma rede de retaguarda ou à falta de integração desta quando presente.

Essas autoras apontam ainda a existência de práticas pautadas em concepções retrógradas no que se refere aos princípios da política vigente em Saúde Mental. Esclarecem que algumas práticas são normatizadoras, fundadas em concepções moralistas, repressivas ou de caráter discriminatório. Observam, também, intervenções que se restringem à medicalização de condições de sofrimento ou de questões sociais. Nesse sentido, para Lucchese et al (2009), é comum que se observe a medicalização de sofrimentos que envolvem situações como rupturas de laços familiares e comunitários, como nos casos de migração, situações que envolvem luto, desemprego, entre outros. Algo que se dá na constante tensão com uma preocupação com a integralidade, a interdisciplinaridade e a participação do usuário na construção do projeto terapêutico.

Nesse cenário, dialogando com documentos ministeriais e com estudos produzidos sobre as ações em Saúde Mental desenvolvidas pelas equipes de Saúde da Família e pelo NASF, buscaremos produzir reflexões sobre as concepções de Saúde Mental, bem como sobre a integração das ações entre os profissionais para o estabelecimento de uma prática interdisciplinar.

Para isso, realizaremos uma breve contextualização sobre a implantação da ESF na região em que este estudo foi desenvolvido, buscando caracterizar o território de atuação dos profissionais participantes desta pesquisa. 


\section{SOBRE A PESQUISA}

\subsection{Conhecendo o campo de pesquisa: breve histórico sobre a implantação da ESF e NASF na região leste do município de São Paulo}

A Estratégia de Saúde da Família começou a ser implantada na capital paulista em 1995, por meio de parceria estabelecida entre o Ministério da Saúde, a Secretaria da Saúde do Estado de São Paulo e duas organizações sociais sem fins lucrativos: a Casa de Saúde Santa Marcelina e a Fundação Zerbini. A criação das primeiras equipes de Saúde da Família foi denominada projeto Qualidade Integral em Saúde (Qualis) (BOUSQUAT et al., 2006).

A criação das primeiras equipes de Saúde da Família por intermédio da estruturação do Qualis no município de São Paulo conferiu à implantação dessa política características singulares, pois esta se deu por meio de uma iniciativa do governo estadual, e não da gestão municipal, como vinha ocorrendo nos demais municípios brasileiros. Tal particularidade é decorrente de decisões políticas e administrativas assumidas pelo governo municipal do período que compreendeu os anos de 1993 a 2000. A gestão responsável pela direção, nesse intervalo, adotou o Plano de Assistência à Saúde (PAS), que preconizava a transferência de recursos públicos para agentes privados (cooperativas), gerando, como lembra Matsumoto (1999), uma gestão descentralizada e privada. Seu modelo de atenção, além de não respeitar os princípios estabelecidos pelo SUS, criou uma série de contradições entre as políticas de saúde municipal, estadual e nacional. Nesse período, verificou-se o sucateamento dos serviços de saúde, principalmente no âmbito da Atenção Básica.

Nesse contexto, o projeto Qualis foi instituído como alternativa para a implantação de uma proposta de atenção à saúde que se aproxima das ideias concebidas pela ESF. Esse programa propunha um trabalho pautado em três conceitos essenciais: o de grupo, o de território e o de responsabilização, e, tal como a ESF, preconizava a implantação das equipes de Saúde da Família para atuarem junto à comunidade.

Vale ressaltar, como aponta Capistrano Filho (1999), que embora o projeto Qualis tenha sido implantado como proposta que contrariava a gestão municipal vigente no período, a iniciativa contou com a mobilização da comunidade. Representantes de 
moradores dos bairros onde a proposta foi implantada tiveram a oportunidade de se reunirem com técnicos responsáveis pela construção do programa para o debate das necessidades da população e a estruturação de serviços condizentes com a realidade de cada comunidade.

Esse processo de implantação instaurou possibilidades de diálogo entre técnicos detentores de saberes científicos, acadêmicos e a população, provida de conhecimentos adquiridos na construção de estratégias e de práticas populares de manejo e enfrentamento do processo de adoecimento.

As primeiras equipes que compuseram o projeto Qualis foram instauradas na região leste do município de São Paulo, o que tornou essa iniciativa pioneira na implantação das futuras equipes de Saúde da Família na cidade.

As equipes do projeto tinham como objetivo proporcionar atenção integral à família, com intervenções a serem realizadas pelos profissionais das equipes de Saúde da Família e de Saúde Bucal em diálogo com serviços ambulatoriais especializados. A experiência do Qualis apontava também para a implantação de equipes volantes de profissionais da área de Reabilitação e Saúde Mental, pois as Unidades Básicas de Saúde, naquela ocasião, contavam com alguns profissionais como fisioterapeutas, fonoaudiólogos, terapeutas ocupacionais, psicólogos, entre outros (CAPISTRANO FILHO, 1999).

Em 2001, sob nova direção municipal, a Secretaria Municipal de Saúde tomou para si o compromisso de reconstruir o SUS no município de São Paulo, assumindo a gestão da Atenção Básica em Saúde. O Qualis foi extinto, dando lugar à Estratégia de Saúde da Família, implantada em todo o município.

Desde então, para a operacionalização e implantação de novas equipes de Saúde da Família, a Secretaria Municipal de Saúde vem utilizando uma modalidade de parceria e de estabelecimento de convênios com instituições privadas. Essa forma de implantar a política de Atenção Básica merece destaque, pois de certa forma representa a continuidade e a expansão da experiência de parcerias iniciadas com o Qualis. Essas entidades são responsáveis por diversas atividades, que podem compreender apenas a contratação de profissionais para atuarem nas equipes de Saúde da Família, desenvolvendo papel administrativo dos recursos humanos, ou podem agregar outras funções como, por exemplo, a capacitação de recursos humanos, a coordenação e a supervisão das equipes (BOUSQUAT et al., 2006). 
Atualmente, após passar pelo processo de municipalização e resgate dos princípios organizacionais apresentados pelo SUS, o município de São Paulo possui cinco Coordenadorias Regionais de Saúde (CRS): a CRS Norte, a CRS Sul, a CRS Centro-Oeste, a CRS Sudeste e a CRS Leste. Cada CRS é subdividida em Supervisões Técnicas de Saúde.

A CRS Leste, regional em que este estudo foi desenvolvido, possui atualmente 55 Unidades Básicas de Saúde, 245 equipes de Saúde da Família e 20 equipes NASF (SÃO PAULO, 2013b).

A implantação do NASF no município de São Paulo teve início em julho de 2008, com a proposta de criação de 86 equipes. Cada Coordenadoria Regional de Saúde pôde elencar, de acordo com o perfil epidemiológico e estudo das principais demandas de cada região, os profissionais que iriam compor os NASF a serem implantados. A Coordenação de Atenção Básica da Secretaria e a Secretaria Municipal de Saúde recomendaram, no entanto, que houvesse a priorização de contratação de profissionais das áreas de Saúde Mental, Reabilitação e Ginecologia, considerando os dados epidemiológicos do município.

Após a contratação dos profissionais, implantou-se um cronograma de capacitação. Foram apresentados às equipes NASF o perfil epidemiológico, econômico, social, demográfico, além dos equipamentos e recursos disponíveis em cada território ( $\mathrm{S} A ̃ \mathrm{O}$ PAULO, 2009).

Na ocasião da capacitação, os profissionais do NASF receberam orientações quanto às metas de ações, que se distribuiriam em quatro eixos principais: as ações compartilhadas (reuniões de equipe, reuniões técnicas, consultas, atendimento em grupo e oficinas etc.), os atendimentos específicos (consultas, grupos e oficinas que exigissem conhecimentos específicos de cada núcleo de saber), as ações intersetoriais (reuniões e articulações com recursos da comunidade e com o Conselho Gestor da UBS ) e, por fim, as outras atividades (reuniões entre os profissionais do NASF, trabalhos administrativos, entre outros).

A Unidade Básica de Saúde em que este estudo foi realizado pertence a uma Supervisão Técnica de Saúde da CRS Leste que possui sete Unidades Básicas de Saúde tradicionais e sete Unidades Básicas de Saúde com Estratégia de Saúde da Família, que contam com 33 equipes de saúde da família. Em 2009 foram implantadas três equipes NASF, que devem ser referência para as sete Unidades Básicas de Saúde do território (SANTA MARCELINA, 2011). 
O bairro apresenta uma importante rede de serviços de saúde, o que facilita a orientação de fluxos de encaminhamentos de casos mais graves acolhidos pelas equipes de Saúde da Família. Além das unidades de Atenção Básica, conta, no âmbito das ações especializadas, com dois ambulatórios de especialidades, duas unidades de Assistência Médica Ambulatorial (AMA) e um Centro de Especialidades Odontológicas (CEO).

Com relação aos serviços especializados em Saúde Mental, possui um Centro de Atenção Psicossocial Álcool e Drogas (CAPS ad) e um Centro de Atenção Psicossocial (CAPS). Já no que se refere aos cuidados em reabilitação, a ESF apresenta como serviços especializados de referência um Núcleo Integrado de Reabilitação (NIR) e um Núcleo Integrado de Saúde Auditiva (NISA).

Por fim, a região possui um Centro de Referência em plantas medicinais e práticas naturais em saúde, um Centro de Testagem e Aconselhamento em Doenças Sexualmente Transmissíveis e Aids (CTA DST/AIDS) e um Pronto-Socorro Municipal (PSM) (SANTA MARCELINA, 2011).

A UBS em que foi realizada a presente pesquisa foi inaugurada em 2002 e, em fevereiro de 2008, a Organização Social de Saúde (OSS) Santa Marcelina assumiu sua gestão. A administração desta UBS está circunscrita à Supervisão Técnica de Saúde Guaianases e à Coordenadoria Regional de Saúde Leste, porém sua gestão é realizada pela OSS Santa Marcelina, segundo contrato de parceria firmado com a Secretaria Municipal de Saúde de São Paulo.

A unidade funciona das 7 às 17 horas e é responsável pelo atendimento de aproximadamente 5.892 famílias. É composta por seis equipes de saúde da família, uma equipe de saúde bucal, um farmacêutico, dois técnicos em farmácia, onze funcionários administrativos e uma equipe NASF composta por: nutricionista, educador físico, psicólogo, dois terapeutas ocupacionais, dois fisioterapeutas, fonoaudiólogo e assistente social.

\subsection{Principais aspectos metodológicos}

Com o intuito de proporcionar o estabelecimento de reflexões sobre as práticas em Saúde Mental que compõem o cotidiano de trabalho dos profissionais da ESF e NASF, o presente estudo tem como base a pesquisa qualitativa. Minayo (2003) esclarece que a pesquisa qualitativa busca compreender o universo dos significados, motivações, 
aspirações, crenças, valores e atitudes, ou seja, aquilo que se refere às relações, processos e fenômenos não mensuráveis.

Enquanto método para operacionalizar o alcance dos objetivos propostos, foi realizado um estudo de caso. O estudo de caso propõe ao pesquisador debruçar-se em profundidade e exaustivamente sobre determinado objeto de estudo, tendo como frente de pesquisa a coleta de dados por meio de diferentes fontes de evidências. Yin (2010) ressalta a importância da aplicação do método a um número restrito de 'casos', garantindo assim a profundidade de investigação requerida pelo método.

Por se tratar de uma pesquisa interessada em refletir sobre a prática e o funcionamento do trabalho desenvolvido pelas equipes da ESF e do NASF, o diálogo estabelecido com os profissionais se constituiu como espaço privilegiado neste estudo.

Participaram desta pesquisa uma equipe de Saúde da Família composta por seis agentes comunitárias de saúde, duas auxiliares de enfermagem, um médico e uma enfermeira, e uma equipe de NASF composta por uma psicóloga, uma assistente social, um educador físico, uma nutricionista, uma fonoaudióloga, duas terapeutas ocupacionais e duas fisioterapeutas. A Unidade Básica de Saúde é composta, ainda, por duas equipes de Saúde Bucal, mas apenas um dos odontólogos participou deste estudo. ${ }^{8}$

A coleta de dados envolveu três etapas: observação de reuniões, análise de prontuários e realização de grupos focais.

A observação das reuniões de equipe teve como objetivo geral compreender a maneira como os profissionais se relacionam e como são construídas as intervenções e práticas em Saúde Mental. Dessa forma, foram observados os seguintes aspectos: pessoas presentes na reunião, assuntos discutidos, desenvolvimento das discussões de caso, principal problemática abordada em relação aos casos, forma de participação dos profissionais na reunião, estabelecimento de metas e tarefas referentes a projetos terapêuticos e principais encaminhamentos elaborados para os casos discutidos.

\footnotetext{
${ }^{8}$ Esta pesquisa foi orientada pelos princípios éticos previstos na Resolução 196/96 do Conselho Nacional de Saúde. Com o objetivo de garantir o anonimato dos participantes, assim como dos usuários do serviço, nomes fictícios foram criados. Os participantes assinaram o Termo de Consentimento Livre e Esclarecido, sendo informados sobre todas as questões referentes à pesquisa e sua participação. O presente estudo teve sua autorização determinada pelo Comitê de Ética em Pesquisa da Secretaria Municipal de Saúde do Município de São Paulo, segundo aprovação n CAAE 0011.0.134.162-11, parecer nº 209/11 (CEP/SMS) emitido em 08/07/2011.
} 
Foram observadas reuniões de equipe ocorridas nos meses de novembro e dezembro de 2011, o que resultou no total de onze encontros: cinco reuniões de equipe em que estavam presentes apenas os integrantes da equipe de Saúde da Família, cinco reuniões em que estavam presentes os profissionais da equipe de Saúde da Família e do NASF e uma reunião em que estavam presentes os integrantes da equipe de Saúde da Família e o odontólogo da UBS.

Na UBS em que o estudo foi desenvolvido, as reuniões de equipe de Estratégia de Saúde da Família têm duração de uma hora e acontecem diariamente, no primeiro horário de trabalho.

O NASF é responsável por atender três Unidades Básicas de Saúde da região. Às segundas e quartas-feiras os profissionais trabalham na UBS em que se desenvolve a presente pesquisa. Esta UBS é composta por seis equipes de Saúde da Família. Às terçasfeiras eles se encontram em outra UBS, que possui duas equipes de Saúde da Família, e às quintas-feiras permanecem em uma terceira UBS composta por três equipes. Assim, a equipe NASF é responsável por oferecer apoio para um total de onze equipes de Saúde da Família.

Os profissionais do NASF participam das reuniões da equipe estudada apenas às segundas-feiras. Para operacionalizar sua presença em todas as reuniões da UBS, os profissionais se organizam em duplas de referência, e a cada mês troca-se um dos componentes da dupla. Essa organização parece responder a duas questões: garantir a participação do NASF semanalmente nas reuniões da ESF e facilitar o acompanhamento longitudinal dos casos discutidos e atendidos, por meio da manutenção de pelo menos um dos profissionais do NASF a cada mês.

Após a observação das reuniões de equipe, foi solicitado aos profissionais que indicassem prontuários de famílias que são atendidas devido a alguma queixa relacionada à Saúde Mental. Os prontuários analisados foram, então, selecionados pelos próprios profissionais da ESF e do NASF. Tal análise apresentou como objetivo aprofundar o conhecimento sobre os registros referentes às intervenções e ao acompanhamento das famílias atendidas.

A leitura dos prontuários foi guiada pela observação dos seguintes aspectos: primeiras queixas relacionadas ao adoecimento mental, principais intervenções, estabelecimento de diagnósticos, profissionais envolvidos nas intervenções, principais encaminhamentos dados para o caso, registros referentes ao projeto terapêutico construído 
pela equipe, intervenções da equipe com o conjunto familiar e participação de serviços especializados de saúde nas intervenções propostas.

Foram analisados sete prontuários. Quatro casos relacionavam-se a mulheres com alguma questão relacionada ao adoecimento mental, um relacionava-se a um homem, um era sobre um adolescente e um tratava do caso de uma criança.

Vale apresentar algumas informações sobre a composição desse documento. $\mathrm{Na}$ capa do prontuário de família constam: o número do cadastro, o nome da Unidade Básica de Saúde, do agente comunitário de saúde e do usuário responsável pela família, e o endereço e telefone da família cadastrada. Além disso, há informações sobre o nome, data de nascimento, sexo, estado civil, escolaridade e doença ou condição referida de cada componente da família.

O prontuário contém a ficha de identificação de cada pessoa, a ficha clínica, a ficha da equipe de Odontologia e os relatórios sobre as visitas domiciliares. Esses relatórios são elaborados pelas agentes comunitárias de saúde e, em seguida, a enfermeira da equipe faz a leitura do material e assina. Dos prontuários analisados, apenas um deles continha tal relatório. As agentes comunitárias de saúde me explicaram que seus relatórios raramente ficam no prontuário, pois como estão constantemente em visita, mantêm-no consigo para evitar perda de tempo da retirada e recolocação da ficha no prontuário. Quando questionei se os demais profissionais tinham o hábito de ler os relatórios de visita, as agentes comunitárias de saúde me explicaram que o médico e enfermeira os leem quando precisam verificar algo específico, para comprovar se a ACS fez a visita quando o cadastrado reclama ou para verificar que as ACS realizaram as visitas conforme cada planejamento. Ou seja, o relatório é utilizado, também, como instrumento de fiscalização e controle do trabalho.

No que se refere ao prontuário das famílias, é importante ressaltar que o agente comunitário de saúde tem acesso apenas ao relatório das visitas que ele mesmo faz. Para garantir sigilo, eles não podem ler o prontuário clínico das famílias que não acompanham. O restante dos profissionais pode acessar todo o conteúdo de prontuários e relatórios. ${ }^{9}$

\footnotetext{
${ }^{9}$ Vale ressaltar que há certa incoerência ao se determinar que o A CS não deva ter acesso aos prontuários para que seja garantido o sigilo, pois o agente de saúde é o integrante da equipe que mais realiza visitas domiciliares, estando em contato constante com a rotina das famílias. Além disso, durante as discussões de caso esses profissionais têm acesso a informações sobre as famílias e o sigilo nem sempre se coloca como premiss a nesses encontros.
} 
A leitura dos prontuários apresentou um elemento que trouxe certa limitação para sua análise: a caligrafia dos profissionais, especialmente do médico, que, por diversas vezes, impediu a realização da leitura. Por isso, a análise ficou restrita àquilo que foi possível compreender com mais exatidão. Tal fator é de extrema relevância, pois a impossibilidade de compreensão pode dificultar a comunicação entre os profissionais e o conhecimento sobre as intervenções propostas em cada caso.

Por fim, optou-se pela realização de grupos focais como estratégia para acompanhar e avaliar experiências, práticas e serviços, a partir da perspectiva dos sujeitos neles envolvidos, considerados alicerce de todo o trabalho da Estratégia de Saúde da Família. Como propõe Westphal (1992), essa técnica possibilita a compreensão da formulação de opiniões, representações, sentimentos e tomadas de atitudes acerca de determinado fenômeno - em nosso caso, a compreensão sobre as concepções formuladas acerca do processo de adoecimento mental, as representações e forma de relacionamento com esse fenômeno, a prática desenvolvida no âmbito da Saúde Mental, bem como o desenvolvimento do trabalho em equipe -, permitindo também verificar como o grupo definia um problema e avaliava uma experiência.

As questões que guiaram a realização dos grupos focais foram as seguintes: (i) $\mathrm{O}$ que compreendem como Saúde Mental e doença mental? Quais são as suas percepções com relação aos problemas de Saúde Mental da população atendida na Unidade Básica de Saúde? (ii) E quanto à prática, quais as ações que a equipe desenvolve para garantir o cuidado em Saúde Mental? (iii) Como percebem a articulação dos profissionais da ESF e do NASF no que se refere às proposições de intervenções em Saúde Mental? Pedimos também exemplos de situações em que se identificasse a articulação das equipes.

Foram realizados dois grupos focais com duração aproximada de uma hora e meia cada. No primeiro grupo focal, realizado em 5 de março de 2012, estavam presentes o médico da equipe, a enfermeira, as agentes comunitárias de saúde (Rosa, Maria, Manuela e Elisa) e a terapeuta ocupacional Daniela. ${ }^{10}$

Vale ressaltar que neste primeiro grupo, realizado em um salão de festas, espaço da comunidade cedido para a equipe de ESF para a realização de grupos e palestras, houve a

\footnotetext{
${ }^{10}$ Com o objetivo de garantir o anonimato dos profissionais e da população atendida na Unidade Básica de Saúde, os nomes apresentados são fictícios.
} 
participação de apenas um componente da equipe NASF - a terapeuta ocupacional que trabalha no período da tarde. ${ }^{11}$

Com o objetivo de compreender o motivo da pouca participação da equipe NASF nesse encontro, ao final do grupo procurei os profissionais na UBS e encontrei-os preparando o material para a apresentação de uma experiência exitosa da equipe, a ser apresentada no evento de comemoração de seus três anos de atuação ${ }^{12}$ para as demais equipes NASF da região. Logo que cheguei à sala em que estavam trabalhando, os profissionais mostravam-se bastante insatisfeitos, dizendo-me que estavam chateados porque a fonoaudióloga e uma das terapeutas ocupacionais da equipe haviam sido transferidas para trabalharem em um CAPS infantil da região e que a assistente social também havia solicitado sua transferência. Comentaram que estavam cansados, pois no dia de comemoração do NASF, como presente estavam ganhando mais trabalho. Um dos profissionais chegou a questionar qual a relevância de minha pesquisa.

Duas semanas depois, retornei à UBS para agendar uma data para a realização do segundo grupo focal. A equipe estava bem diferente, dizendo terem gostado da comemoração de aniversário de três anos de implantação do NASF e que apresentaram a Jornada de Clínica Ampliada como uma experiência exitosa da equipe, experiência que se destacava das apresentadas pelas outras equipes. Nesse dia, pareciam mais satisfeitos com o trabalho. Então, acertamos a data para a realização de nos so segundo encontro.

O segundo grupo focal foi realizado em 4 de maio de 2012, tendo como participantes uma das auxiliares de enfermagem e os seguintes profissionais do NASF: educador físico, nutricionista, fonoaudióloga, psicóloga, uma das terapeutas ocupacionais e uma das fisioterapeutas.

A composição de cada grupo focal chama a atenção. No primeiro estavam presentes os profissionais da ESF e apenas um integrante da equipe NASF. No segundo encontro estavam presentes os profissionais do NASF e uma das auxiliares de enfermagem da equipe de ESF.

\footnotetext{
${ }^{11}$ Há algumas categorias profissionais do NASF que, devido a legislações de conselhos regionais de regulação da profissão, não podem ser contratadas para cumprir u ma jornada de trabalho que ultrapasse a carga horária de trinta horas semanais. Os fisioterapeutas e terapeutas ocupacionais se encaixam nessa determinação. Para que se cu mpra a exigência da portaria do NASF que institui que sejam disponibilizadas quarenta horas de trabalho para cada categoria profissional, são contratadas duas terapeutas ocupacionais: uma atua no período da manhã e outra no turno da tarde.

${ }^{12}$ A data de realização do primeiro grupo focal coincidiu com a semana de comemoração de três anos de implantação das equipes NASF na região.
} 
Embora o grupo estivesse agendado, as agentes comunitárias estavam no território, a enfermeira estava de licença médica e o médico estava em atendimento e não poderia participar das discussões. Uma das auxiliares de enfermagem explicou que não poderia deixar suas atividades no acolhimento e que não gostaria de participar por não se sentir à vontade para falar na frente de toda a equipe NASF. Apenas uma das auxiliares aceitou participar do encontro.

Essa situação talvez nos permita pensar sobre como se desenvolvem as relações entre essas equipes e o efeito delas no cotidiano de trabalho. Como ser interdisciplinar se as pessoas têm dificuldade em dialogar? Como realizar um trabalho conjunto se há dificuldade para os encontros? O segundo grupo focal, assim, nos permitirá refletir sobre essas questões.

A partir de cada uma das fases de coleta de dados foi possível entrar em contato com questões que dialogavam entre si, encontrar pontos de ressonâncias e algumas contradições, o que proporcionou elementos para compor uma reflexão sobre a prática desses profissionais no campo da Saúde Mental.

O trabalho de campo possibilitou o acompanhamento mais aprofundado do funcionamento da equipe com relação à intervenção, em alguns casos. Foi possível observar parte da discussão clínica des ses casos. Em seguida, a equipe sugeriu a leitura dos prontuários, e, por fim, algumas questões sobre esses casos emergiram nos grupos focais. A possibilidade de refletir sobre o funcionamento dessas equipes por meio do acompanhamento do caso nos chamou a atenção. Diante disso, optamos por apresentar um desses casos clínicos como um disparador, isto é, como um "contexto" do qual extrairemos os temas relevantes para as discussões deste trabalho.

A partir disso, procederemos à análise proporcionada pela triangulação dos dados advindos das diferentes fontes de evidências, o que culminou na elaboração dos seguintes temas: concepções dos profissionais sobre Saúde Mental, relação dos profissionais com o adoecimento mental, prática (propostas, ações e principais dificuldades), organização do trabalho e o trabalho em equipe.

\subsection{Sobre o caso Marlene}

A apresentação deste caso se coloca neste trabalho como um elemento disparador para a apresentação e discussão dos temas relacionados à prática dos profissionais da ESF 
e NASF. O objetivo é tentar compreender o funcionamento da equipe em seu cotid iano de trabalho e não tecer considerações a respeito do caso clínico, nem mesmo avaliar ou julgar as intervenções propostas pelos profissionais. Diante disso, deteremo-nos nos elementos que permitem refletir sobre o modo de trabalhar em equipe ao se depararem com uma situação que envolve o adoecimento mental.

Durante a observação de reuniões de equipe, foi possível entrar em contato com a história de Marlene. O caso não era discutido extensamente durante as reuniões, pois os profissionais da ESF resolveram apresentar a situação de adoecimento vivenciada por Marlene à discussão e estudo na Jornada de Clínica Ampliada.

Trata-se de um encontro entre todos os profissionais do NASF com os profissionais das equipes de Saúde da Família da Unidade Básica de Saúde, que acontece mensalmente e tem como objetivo a discussão de um caso eleito por cada equipe para a elaboração de um Projeto Terapêutico Singular. Propõe-se a discussão concomitante à educação continuada sobre temas escolhidos pelos profissionais.

Esse espaço foi criado estrategicamente pela equipe NASF para viabilizar a realização do matriciamento, pois segundo relatos dos profissionais, durante as reuniões de equipe, as demandas por agendamentos de atendimentos dificultavam a concentração das equipes para o estabelecimento da discussão extensa de um caso mais complexo.

Embora a discussão de caso sobre Marlene tivesse um espaço reservado na Jornada de Clínica Ampliada, durante as reuniões de equipe, eram frequentes os comentários entres os profissionais. A ACS Maria muitas vezes comentava: “Gente, a Marlene está piorando...". Era possível perceber que todos conheciam Marlene e que havia uma preocupação e comprometimento dos profissionais com o caso, o que fica explícito quando a equipe escolheu esse caso como prioridade para discussão em Jornada de Clínica Ampliada com o NASF.

Ainda durante as reuniões foi possível observar certa insatisfação dos profissionais da ESF com relação às discussões e intervenções propostas, pois certa vez uma das agentes comunitárias de saúde comentou que não queria mais discutir o caso na Jornada de Clínica Ampliada. Alguns profissionais diziam que não estavam observando melhora alguma e que só não deixavam de discutir o caso porque queriam "ir até o final" para "ver onde vai dar $[\mathrm{sic}] "$.

Ao finalizar as observações de reunião de equipe, como proposta de análise de prontuários, foi solicitado às equipes ESF e NASF que indicassem prontuários de famílias 
que recebiam algum tipo de cuidado em Saúde Mental. O prontuário de Marlene foi um dos primeiros a ser citado.

Marlene reside com seu esposo e com a filha. Os primeiros registros de acompanhamento de Marlene pela equipe de Saúde da Família foram feitos em junho de 2009. Nesta ocasião, o médico registrou que a usuária referia sentir "insônia, inapetência, agitação e ansiedade", relatando ter sido diagnosticada como depressiva e que desde então vinha sendo medicada com amitriptilina, prometazina, risperidona, poroxetina e velafaxina, não observando melhora.

Naquele mesmo mês, consta o registro de uma discussão de caso com a equipe NASF. Os profissionais da ESF referiam que Marlene tinha se queixado dos remédios que utilizava, solicitando a troca de tais medicamentos. Nessa reunião a equipe determinou o agendamento de uma visita domiciliar a ser realizada pela terapeuta ocupacional.

Há, então, uma lacuna nos registros, e as próximas anotações foram feitas em abril de 2010, mês em que a terapeuta ocupacional realizou uma visita domiciliar e providenciou o encaminhamento de Marlene ao grupo de convivência realizado na UBS.

A leitura do prontuário permite observar que no início do acompanhamento de Marlene as intervenções propostas pela ESF eram exclusivamente medicamentosas. Após a discussão de caso com a equipe NASF houve o encaminhamento para o grupo de convivência, mas não constam registros de sua participação nem anotações relatando ações da equipe para a vinculação de Marlene no grupo para o qual foi encaminhada. Não é possível saber se ela não compareceu ou se sua participação não foi registrada pelo profissional coordenador do grupo.

Após esse registro existe outra lacuna de quatro meses na evolução do prontuário, e as próximas anotações foram feitas em agosto de 2010. Na ocasião houve uma discussão de caso com a equipe do NASF em que a ACS relatou que Marlene "piorou". Os profissionais agendaram, então, uma consulta com a psicóloga do NASF. Consta registro de que Marlene não compareceu ao atendimento.

No mês seguinte, setembro de 2010, a psicóloga realizou visita domiciliar junto com a terapeuta ocupacional, mas não foram atendidas. Segundo a vizinha, Marlene encontrava-se em casa e não queria atender os profissionais da UBS.

Entre setembro de 2010 e janeiro de 2011 há outra lacuna nos registros do prontuário. Esses lapsos não nos permitem saber se foram feitas intervenções não registradas ou se não foram desenvolvidos atendimentos no período. 
No intervalo que compreende os meses de janeiro e junho de 2011 há registros de algumas consultas realizadas pelas auxiliares de enfermagem e pelo médico, porém não há registros sobre o estado emocional de Marlene. A ausência de registros sobre a situação de saúde mental não significa necessariamente que esses aspectos não foram abordados pelos profissionais, significa apenas que não há registros de observação ou intervenções relacionadas às condições emocionais. Além disso, vale lembrar que a dificuldade para entender a caligrafia dos profissionais prejudica a compreensão sobre as intervenções.

Em 15 de julho de 2011, o caso passou a ser discutido na Jornada de Clínica Ampliada com o NASF. Há registro de realização de discussão a partir da construção do genograma de Marlene.

Na mesma data há informações relacionadas à participação de Marlene no grupo realizado pelos profissionais do NASF na Unidade Básica de Saúde. Há relato de que a mesma vinha frequentando o grupo de mulheres desde outubro de 2010 e que tinha apresentado participação "pró-ativa", fazendo "bom vínculo com a equipe e com as demais participantes".

Ainda em 15 de julho de 2011, há anotações sobre uma visita domiciliar realizada pela psicóloga e nutricionista do NASF. Tais profissionais relataram que Marlene tinha permanecido parte do dia na casa da vizinha porque dizia sentir "nojo de tudo em sua casa", que sua "casa era escura" e que não gostava nem mesmo de estar na casa da vizinha. A usuária contou que "não sentia prazer em nada", que "não se achava uma boa mãe" porque não conseguia fazer as atividades diárias como realizar a limpeza e cozinhar. Além disso, relatou o desejo de se separar do esposo.

Nessa ocasião, Marlene referiu "descrença" no tratamento psiquiátrico, contudo aceitou ser encaminhada para o psiquiatra do serviço ambulatorial especializado em Saúde Mental da região.

No mês seguinte, agosto de 2011, foi realizada outra visita domiciliar pela psicóloga e nutricionista do NASF. Marlene alegou não conseguir ficar sozinha em casa e nessas ocasiões permanecia na calçada à espera da filha ou esposo. Contou que não conseguia "cuidar da casa", que tinha a "sensação de que iria morrer" e que "tudo estava escuro". Referiu ainda que sentia "não ser boa mãe" e temia que sua filha "ficasse como ela". Marlene contou que não foi à consulta agendada no ambulatório porque não tinha companhia. A filha, então, se comprometeu a acompanhar a mãe no atendimento seguinte. 
Ainda nesse mês, em reunião da Jornada de Clínica Ampliada, a equipe rediscutiu o caso, registrando que o Projeto Terapêutico Singular de Marlene compreenderia: inserção de Marlene na Unidade de Apoio em Saúde Mental - Ambulatório de Especialidades; sistematização de visitas domiciliares a serem realizadas pelos profissionais da ESF e NASF, além das visitas da ACS; e, por fim, realização do grupo de mulheres no dia 14/09/2011, na área em que mora, para facilitar seu acesso.

Não há relatos sobre a realização do grupo de mulheres desenvolvido na área próxima à casa de Marlene.

Na reunião de Jornada de Clínica Ampliada realizada em setembro de 2011, a ACS referiu que houve piora no quadro de saúde de Marlene, apontando que ela não estava tomando os medicamentos e que chegava a colocar os remédios nas bebidas do marido. A equipe reagendou grupo de mulheres para o dia 21 de setembro.

Há, então, uma folha avulsa, porém fixada ao prontuário, com o registro de uma visita domiciliar realizada pela fonoaudióloga da equipe NASF em abril de 2011. Nesta visita, a profissional relatou ter conversado com a filha de Marlene sobre as condições de saúde da mãe, mas não há detalhes sobre o diálogo. Há também uma folha de encaminhamento realizado pela terapeuta ocupacional ao serviço ambulatorial de Saúde Mental com a data de 12 de julho2010.

Esses registros estão desconectados, não há evolução temporal e não é possível identificar o motivo dessa descontinuidade. Porém, após esse desencontro de datas, há registros de que foi realizado o grupo de mulheres em 21 de setembro, conforme agendamento.

Consta que Marlene participou do encontro, mencionando sentir muita tristeza. Contou à equipe que colocava fluoxetina na bebida do esposo "para que ele a deixasse em paz".

Em 30 de setembro de 2011 há informações de que foi agendada uma visita domiciliar, que não foi realizada.

No mês de outubro do mesmo ano, Marlene passou por duas consultas com o médico, referindo "sensação de engasgo". Não foi possível compreender os demais registros feitos por es se profissional.

Em novembro de 2011, o caso de Marlene foi discutido com a equipe do ambulatório de especialidades para o qual ela havia sido encaminhada, e a psicóloga desse serviço informou à profissional do NASF que a usuária não tinha comparecido aos 
atendimentos porque não foi possível fazer contato telefônico. Diante disso, os profissionais acordaram que o próximo agendamento deveria ser informado a algum profissional da UBS e este transmitiria o recado, evitando assim mais uma perda de vaga.

Após esse registro, consta que a equipe NASF discutiu, em reunião com o CAPS, a possibilidade de realização de encaminhamento de Marlene para esse serviço.

No dia 28 de novembro de 2011, o caso foi discutido pelas equipes ESF e NASF, e há relato de que Marlene encontrava-se em "quadro depressivo severo" e que apresentava dificuldade para realização de atividades de autocuidado.

O último registro observado estava relacionado a uma visita domiciliar realizada pela assistente social, psicóloga e nutricionista da equipe NASF: em 5 de novembro de 2011 , tais profissionais registraram que Marlene referia "não ver sentido nas coisas" e não ter planos futuros.

Além das informações na ficha de Marlene, havia no prontuário uma folha avulsa de relatório de encaminhamento com data de setembro de 2011 para acompanhamento psicoterapêutico em ambulatório de especialidades. Neste relatório, consta diagnóstico de Transtorno Afetivo Bipolar e alguns relatos sobre o quadro de sintomas. A psicóloga referia que a usuária apresentava dificuldade em aderir ao encaminhamento porque quando vivenciava momentos depressivos entrava em estado de isolamento e em "mania" tinha dificuldade para perceber a necessidade de manter um acompanhamento de suas condições de saúde.

A leitura do prontuário possibilitou a observação de algumas questões: a forma de comunicação sobre os procedimentos realizados, a dificuldade dos profissionais em manter atualizados os registros sobre as intervenções, as lacunas e desencontros entre as datas em que os registros são realizados. Contudo, foi possível notar o grande envolvimento dos profissionais no atendimento à Marlene. A equipe fez diversas tentativas e procurou uma aproximação com o contexto de vida da usuária a fim de propor as intervenções mais condizentes com suas possibilidades.

Os registros no prontuário passaram a ser mais frequentes e elucidativos a partir do momento em que o caso passou a ser discutido na Jornada de Clínica Ampliada. A partir de então, aparecem anotações sistemáticas relacionadas às metas, à divisão de tarefas e às discussões de caso com os profissionais dos serviços especializados de referência.

Contudo, não foi possível observar registros sobre discussões relacionadas às demandas da usuária. Parece que, inicialmente, ela era encaminhada para grupos, 
atendimentos e propostas de intervenções já existentes na UBS ou na rede de serviços especializados. Não observei discussões que tentassem identificar ou, pelo menos, anotações esclarecedoras sobre o motivo da realização de alguns encaminhamentos.

Interessante observar que a ACS Maria comentou, em março deste ano, que Marlene teve quatro surtos desde o começo do ano e piorou, mas não há evoluções em seu prontuário sobre intervenções recentes. Noto amplo envolvimento dos profissionais nesse caso, porém parece haver certa dificuldade em vincular a usuária às intervenções propostas pelas equipes.

Após a leitura da ficha de Marlene, foram realizadas as leituras dos prontuários de seu esposo e filha. Com relação às intervenções familiares, percebo que há início de ações junto à filha de Marlene no sentido de auxiliá-la no trato com a mãe e no enfrentamento de situações de conflito com a mesma.

A organização do prontuário é uma questão que merece atenção, pois a separação das fichas por indivíduos é um elemento que permite refletir sobre a forma como o cuidado se organiza em torno da família. A leitura desse material possibilita observar a fragmentação da família: o cuidado acontece em torno do indivíduo, e a família, quando alvo de intervenções, é vista em relação àquele que adoece.

Os profissionais, por vezes, conseguem elaborar uma reflexão ampliada sobre questões que envolvem o processo de adoecimento como fenômeno de múltiplas determinações, como uma situação relacionada à família e sua complexa rede de relações, no entanto as intervenções parecem pouco incorporar essas concepções.

Foi possível notar que as ações ficam restritas a um campo de intervenções que envolvem a prescrição de medicamentos, o encaminhamento para grupos terapêuticos previamente existentes e para os serviços especializados, ou seja, não foi observada uma ampliação do cuidado para âmbitos que extrapolam o ambiente "convencional" da saúde.

Finalizada a fase de análise do prontuário, foram realizados os primeiro grupos focais com os profissionais. No primeiro encontro, o grupo fez menção ao acompanhamento de Marlene em diferentes momentos, cujos recortes são apresentados a seguir.

O grupo teve início com as discussões sobre concepções relacionadas à Saúde Mental e doença mental. Em seguida, foram abordados aspectos ligados às intervenções propostas nesse campo, às especificidades da Saúde Mental, às dificuldades cotidianas da 
equipe com relação ao diagnóstico e à definição da terapêutica mais adequada para cada situação.

A discussão sobre o caso de Marlene emergiu no momento em que os profissionais discutiam sobre a Jornada de Clínica Ampliada e o Projeto Terapêutico Singular.

\begin{abstract}
A gente discutiu o caso da Marlene e... quando chegou um certo tempo a gente falou assim: A gente não vê mais resultado, a gente não sabe... o propósito disso, vamos ver o que a gente faz, se vai chegar em algum lugar. Mas aí, as meninas até perguntaram se a gente queria parar com o caso e a gente falou que não, já que tava ali a gente queria ver até o fim. E tanto é que a Marlene aderiu ao tratamento. Ela passou a frequentar o CAPS. Ela não ia. Ela ia lá visitar a Tereza [psicóloga que trabalhava no NASF transferida ao CAPS da região recentemente], mas não ia fazer o tratamento (risos). É, ela ia visitar a Tereza, porque ela é apaixonada pela Tereza, mas ela fazia... não aderia ao tratamento (risos). E quando a gente viu, a gente pensou: "Pronto, podemos esquecer a Marlene, porque ela tava encaminhada, ela tá indo no CAPS". (Rosa, ACS)
\end{abstract}

Rosa fala sobre a demora e a dificuldade em observarem uma melhora em Marlene. No entanto, ela afirma que houve uma melhora, e esta não parece estar relacionada à diminuição de sintomas ou transformação nas condições de vida. A melhora nem mesmo é referida pela pessoa em acompanhamento, mas sim à adesão ao tratamento: "Pronto, podemos esquecer a Marlene, porque ela tava encaminhada, ela tá indo no CAPS”. Estar seguindo a recomendação da equipe e frequentar o CAPS parece significar para os profissionais que a equipe poderia encerrar as discussões. $\mathrm{O}$ encaminhamento, nesse caso, parece um ponto final do atendimento oferecido pela equipe, pelo menos até que outra crise aparecesse.

Então, a enfermeira da equipe aproveita as falas das agentes sobre a questão das expectativas com relação aos resultados das intervenções, ampliando para a discussão sobre a elaboração do PTS em casos de Saúde Mental.

Então, a dificuldade de trabalhar com essa questão de Saúde Mental é essa, você não... o retorno que você espera ter de um caso, você acaba não tendo. Então, isso é muito complicado. Assim, a questão do PTS; é um instrumento muito importante, só que assim, é aquilo que elas falaram, a gente não tem tempo. Em uma reunião de equipe tem que se trabalhar inúmeras coisas. Têm informes que têm que ser passados, tem discussão de casos que as ACS têm que trazer, tem devolução que a gente tem que devolver de algum paciente que a gente atendeu. Aí quando não tem a participação do NASF, tem a participação da odonto. A gente não tem um espaço, um tempo pra fazer o PTS, a não ser esse da Jornada Ampliada, porque agora a gente está tendo esse espaço pra fazer o PTS. Porque os outros a gente acaba não fazendo. É claro que a gente faz um PTS sem ser escrito, sem ser registrado, na maioria dos casos. Quando a gente traz um 
caso, elas trazem um caso, a gente discute um caso, a gente tenta... a gente vê com o NASF o que é que pode ser feito. O que é que nós da equipe podemos fazer. Porque uma coisa que eu observo na outras equipes, que eu observei, é que... é que as pessoas não sabem direito qual é a função do NASF, então o que elas querem? Elas querem jogar o caso e querem que o NASF resolva. Elas não entendem essa questão do matriciamento, a maioria das equipes. Uma coisa que é... que eu fico muito feliz com isso é que nessa equipe, nessa equipe não tem... (Marta, enfermeira)

Pergunto como é a comunicação na equipe e como percebem o Apoio Matricial. Uma das agentes comunitárias de saúde, Elisa, inicia explicando o matriciame nto a partir da discussão do caso de Marlene. Conta que esse espaço possibilita que eles aprendam a ter novos olhares sobre o processo de adoecimento, esclarece que os profissionais do NASF explicam para eles o que está acontecendo e acrescenta que esse momento de aprendizagem é transferido para o cuidado com outras pessoas atendidas na UBS. Rosa acrescenta que os profissionais do NASF trazem elementos para discussão que permitem a melhor compreensão sobre algumas condições relacionadas ao adoecimento mental. Explica que, por vezes, encarava os sintomas como "frescura" ou como "manipulações" da pessoa para atingir um objetivo, mas a partir da Jornada de Clínica Ampliada pôde notar que alguns comportamentos eram reflexos do adoecimento.

Questiono se eles observam algum resultado positivo a partir das discussões propostas na Jornada de Clínica Ampliada, pois me recordo que, em reuniões de equipe, algumas agentes de saúde diziam que não observavam resultado algum, que os casos não "davam em nada", e agora elas apontavam um aspecto positivo do matriciamento: a transformação do olhar em relação ao processo de adoecimento.

Elisa fala sobre isso: "É que no começo a gente ficou falando muito da mesma pessoa [Marlene] e toda semana a mulher estava ruim. Então a gente começou a ficar rezando: meu Deus do céu, to cansada de falar nessa mulher (risos)". A enfermeira Marta complementa

É que parecia que ela não respondia, que ela não queria ser tratada, entendeu? Porque é difícil mesmo você lidar com a saúde mental, porque você espera um resultado que ele não parece, ele não vem. O resultado que você espera, porque assim o que a gente... a gente que trabalha com a saúde, a gente quer ver a cura da pessoa, né? Que nem, vem uma pessoa com pneumonia, você prescreve, você diagnostica com um raio-x ou com uma ausculta respiratória. Você passa um antibiótico e ela sarou... daí você vê, já com uma questão de saúde mental, a pessoa chega lá em crise, em sofrimento, você faz de um tudo pra ajudar, entendeu? Toda a equipe se mobiliza, vai na casa, liga pra... liga pra um, liga pra outro. Entra em contato com o CAPS, entra em contato com o NIR [Núcleo Integrado de 
Reabilitação], tenta fazer todo um movimento e aquilo ali não dá em nada. É o que aparenta, né? Não dá em nada... Então, aquilo traz uma angústia. É muito angustiante isso, é isso que todo mundo sentiu. Tanto com PTS ou sem PTS a gente continua sentindo isso. Tem uns casos que parece que não evoluem, a gente não consegue medir uma melhora. Não é... passou um tempo que ela estava bem, agora já recaiu de novo. Dá impressão de que a pessoa não quer se tratar. (Marta, enfermeira)

Essas falas mostram que a equipe fica exausta diante das discussões de caso, das intervenções e da distância entre as ações e a obtenção do resultado esperado. A enfermeira traz novamente a discussão sobre a dificuldade do estabelecimento do diagnóstico, do tratamento e dos sentimentos de impotência e angústia diante dos casos atendidos em Saúde Mental. Em seguida, descreve todas as intervenções propostas e a dificuldade na obtenção do resultado desejado e, da mesma forma como iniciou sua fala, termina dizendo que "dá a impressão de que a pessoa não quer se tratar", como se a melhora fosse algo decorrente do desejo da pessoa.

Após ouvir Marta, o grupo prossegue:

Essa semana mesmo, eu e a Maria vimos ela [Marlene] na Unidade e até assustamos, né, Maria? Essa é a Marlene? Ela estava limpinha, arrumadinha, botou... nem parecia a mesma mulher. Parece que ela até engordou. Ela tá bonita... (Elisa, ACS)

Mas quando a gente pensou que não ia, esse caso... ah, vamos sair, vamos sair. De repente, veio uma surpresa, eu encontro ela na rua bem: "Maria, estou indo pro CAPS". Ela conseguiu aderir em alguma coisa, porque ela não conseguia...

Ela conseguiu aderir, e a crise que ela teve, foi num espaço menor. Ela falou assim pra mim: "Maria, a crise foi diferente porque eu, eu fiquei em crise, mas eu comia, eu tomava banho". Coisa que ela não fazia quando ela tava lá na crise dela. Ela não come, não toma banho... (Maria, ACS)

Não sai de casa... Ela falou assim: "Maria, eu comi, eu tomei banho". Eu falei assim: "Eu vi que você está passeando". Ela estava passeando, estava na casa das minhas amigas. Ela falou que foi bem pequena... Eu falei assim pra mim: "Valeu a pena!". (Maria, ACS)

Nesses trechos as profissionais afirmam ter notado a melhora de Marlene. Para elas, esse fato relaciona-se à melhora do autocuidado, à adesão ao tratamento no CAPS, a maior socialização e à menor intensidade da crise.

Essas falas permitem notar conflitos e contradições, pois inicialmente os profissionais afirmavam que a atenção dirigida aos casos de Saúde Mental, apesar de todos os investimentos, não apresentavam resultado. No entanto, ao seguirem com a discussão, os profissionais conseguem identific ar alguns pontos positivos e pequenos avanços. 
Ainda discutindo o PTS elaborado para o estabelecimento do cuidado de Marlene, a terapeuta ocupacional esclarece:

\begin{abstract}
Eu acho assim... às vezes, a gente... é, consegue perceber mais as mudanças, né? Porque, talvez, a gente não esteja tanto nessa lógica da cura. Tipo... queixa e conduta, queixa e conduta que é o que, muitas vezes, vocês acabam vivendo no dia a dia. É... eu percebo melhora, entendeu? Eu acho que é difícil quando o paciente, ele não quer o tratamento, ele fala que não quer, não consegue perceber a necessidade, né? Mas eu acho que é uma ferramenta importante que dá certo, assim... entendeu? Eu já vi que... na maioria dos casos eu acho que vale a pena tentar, mesmo que sejam pequenas mudanças. Igual a Maria falou: a crise foi menor. Quando a gente ouve isso, a gente fica superfeliz, entendeu? Isso aí é um mega resultado pra gente, não é... não é uma coisa pequena. (Daniela, terapeuta ocupacional)
\end{abstract}

Então, tentando compreender melhor a sensação de frustração diante dos resultados desejados e esperados pela equipe, pergunto: "E vocês têm espaço para fazer essa discussão sobre o que é melhora em Saúde Mental? O que é cura?"

Durante a realização do grupo focal, A ACS Maria atribui à falta de tempo o fato de a equipe pouco discutir sobre quais as expectativas diante de um caso, qual a melhora esperada e o que é cura. Daniela procura demonstrar a complexidade da discussão explicitando que a família, o território e o desemprego são elementos que devem estar presentes nessa discussão. Parece que os profissionais têm poucas possibilidades para a elaboração dessa discussão.

Após as observações de discussões, a leitura do prontuário e os apontamentos feitos pelos profissionais sobre a história de adoecimento de Marlene, a apresentação do caso possibilita pensar alguns pontos que merecem uma discussão mais aprofundada. Interessanos refletir sobre a compreensão dos profissionais acerca do processo de adoecimento e sobre a forma como eles se relacionam com esses fenômenos, pois essas reflexões viabilizarão a elaboração de discussões relacionadas a algumas das raízes que fundamentam as intervenções no campo da Saúde Mental. Além disso, interessa-nos destacar algumas considerações sobre a prática no campo da Saúde Mental, o que significa adentrar discussões relacionadas às principais dificuldades, à interlocução com outros serviços de saúde, ao processo de elaboração da intervenção que envolve o Projeto Terapêutico Singular e ao Apoio Matricial e, por fim, compreender como se dá a organização do trabalho e como se desenvolve o trabalho em equipe. 
Dessa forma, apresentaremos os seguintes temas para discussão: concepções sobre Saúde Mental, como os profissionais se relacionam com o adoecimento mental, a prática (propostas, ações e principais dificuldades) e a organização do trabalho

\subsection{Concepções sobre Saúde Mental}

Durante as reuniões de equipe foi possível observar algumas das compreensões com relação à Saúde Mental próprias dos profissionais da ESF e NASF.

Os profissionais da ESF, ao falarem sobre o campo da Saúde Mental, com frequência se referem ao processo de adoecimento como um fenômeno que se dá no indivíduo e relaciona-se a uma disfunção do organismo: "não está batendo bem da cabeça" ou "tem problemas de cabeça" são falas comuns. Essa forma de pensar se aproxima de uma concepção mecanicista sobre o adoecimento mental. Em outros momentos, o adoecimento mental aparece relacionado à ausência de ocupação e ociosidade como causadores de adoecimento, como podemos ver na fala do odontólogo "é assim mesmo: cabeça vazia... oficina do diabo".

Os problemas relacionados ao adoecimento mental são apontados, também, como fenômenos decorrentes de situações familiares.

Durante uma das reuniões de equipe, ao discutir o caso de uma moça com transtorno mental, a agente comunitária de saúde diz que o problema dessa cadastrada é a sua mãe. Explica que a moça reclama da interferênc ia desta em sua vida, conta que ela tem alguns problemas conjugais e que a mãe constantemente opina sobre as situações e cobra que a filha tome determinadas atitudes com relação ao esposo.

$\mathrm{O}$ aprofundamento da discussão sobre as concepções relacionadas à saúde mental foi proporcionado pela realização dos grupos focais. No primeiro encontro o médico esclarece:

Saúde Mental é... relativo ao bem-estar mental da pessoa, quando a pessoa está emocionalmente, psicologicamente bem, ela tem uma boa saúde mental. Se ela tem algum problema que chega a interferir na vida pessoal, na vida profissional... se chega a interferir com outras pessoas, se chega a influenciar outras pessoas, então, daí, a gente tem um problema de Saúde Mental (Valter, médico) 
O médico está mais atento às interferências provocadas pelo adoecimento do que ao estado psíquico da pessoa. Ele relaciona a doença mental a uma situação que envolve o cotidiano, a rotina e as relações aí implicadas.

Uma das agentes comunitárias de saúde complementa essa ideia, relacionando o adoecimento mental a um fenômeno que rompe com a trajetória comum de acordo com o desenvolvimento de comportamentos esperados, segundo o papel social daquela pessoa, ou seja, como situação de ruptura. Além disso, afirma que o adoecimento decorre de situações em que há agressividade, em que a pessoa precisa ser contida por meio de uma internação.

Outros profissionais lembram que o adoecimento não está ligado apenas à agressividade, mas também ao estado emocional: "Às vezes nem agressivo, às vezes, choroso, choroso, choroso... às vezes não é nem agressão" (Manuela, ACS).

A capacidade que o sujeito tem para elaborar suas dificuldades e sofrimentos também aparece em uma das falas.

Tem alguns que são característicos mesmo... é... esquizofrenia, essas coisas... daí já não vem do sofrimento, né? Causa um sofrimento, mas não vem dele. Agora, a depressão, por exemplo, pode vir de um sofrimento mal resolvido [...] Não é só a tristeza em si, é a capacidade daquela pessoa de lidar com aquilo que faz com que ela adoeça ou não. (Marta, enfermeira)

Interessante notar que uma das falas expressa o adoecimento mental como: “[...] uma doença invisível. Não tem como, assim... porque se quebra a perna, né? Você tá lá com uma cirurgia e, dá pra se ver. Agora, problema na mente é uma doença invisível" (Maria, ACS).

Esse trecho evidencia o que mais adiante será abordado intensamente pelos profissionais: a dificuldade do estabelecimento do diagnóstico.

No segundo encontro, os profissionais, ao falarem sobre o que consideram elementos do adoecimento mental, já iniciam uma discussão importante para este estudo: como eles se relacionam com esse fenômeno.

Eu acho que os casos de Saúde Mental sempre são mobilizadores. Eu acho que, como tem essa coisa do comportamento... comportamento que é a palavra. Então, eu acho que tem essa coisa da... da mudança da atitude que, normalmente, é uma coisa que incomoda, que gera mesmo nas pessoas essa coisa do cuidado... (Mirian, nutricionista)

Eu vejo dois momentos, assim ... pensando no que a Mirian falou, né? Um é o mobilizador, pela equipe de NASF, e o momento assustador pela equipe de Estratégia de Saúde da Família. A equipe de Estratégia de Saúde da Família... por quê? Porque expõe o trabalho deles, né? O paciente de Saúde 
Mental expõe o trabalho da equipe de Estratégia de Saúde da Família. A gente precisa fazer alguma coisa urgente porque se não ele vai falar alguma coisa. Alguém vai vir pro... Mobiliza a equipe de NASF por isso. Percebe que a equipe de Saúde da Família não consegue dar conta desde questões mínimas... aí a gente precisa se mobilizar porque sabe os danos que vai causar para o paciente a curto, a médio e a longo prazo, também. Então, eu consigo... pra mim, eu vejo nesse modo, também eu sou um desses que a Mirian falou que não tem esse total entendimento da Saúde Mental, mas... a gente não tem, às vezes, esse preconceito que os profissionais da Estratégia de Saúde da Família têm muito grande. Mas eu vejo assim, é assustador pra eles por quê? Porque vai expor a equipe. O paciente de Saúde Mental, o paciente que tira a roupa, que sai na rua, que ameaça e grita, agride. Ele expõe o trabalho da equipe de Estratégia de Saúde da Família, aí eles vêm buscar um suporte no NASF. O NASF... se mobiliza pra isso, né? E essa responsabilidade é conseguir tratamento. Então, eu acho que a gente começa a se mobilizar, todo mundo, pra tentar trazer eles pra junto, pra junto. Porque eles têm essa sensação: Pronto, agora eu passei pro NASF e o NASF vai dar conta desse paciente. E o paciente é sempre deles, né? A gente só vai dar um suporte. Eles que vão estar ali cuidando do paciente, né? (Miguel, educador físico)

Essas falas revelam que a relação dos profissionais do NASF com a população atendida é mediada pelos profissionais da ESF. A preocupação dos profissionais parece ficar focada na obtenção de bons resultados das intervenções, para que os surtos e o agravamento das condições de saúde não revelem fragilidades ou falhas nas intervenções propostas.

Interessante notar que, embora os profissionais falem sobre aspectos diferentes do adoecimento mental, parece haver um forte registro da doença como um fenômeno orgânico, uma disfunção que se dá no indivíduo provocando rupturas de comportamentos com repercussões no cotidiano e no convívio social. Essa forma de pensar parece interferir na atuação dos profissionais, gerando intervenções repetitivas pautadas nos aspectos biológicos do adoecimento.

A maneira como os profissionais percebem o adoecimento mental interfere diretamente nas ações que irão propor. A capacidade de comunicação entre os profissionais e a circulação de diferentes formas de pensar esse fenômeno e de relacionar-se com ele torna-se uma questão central para a maior ou menor possibilidade de superação de práticas cristalizadas de intervenção.

A análise dos prontuários permitiu observar que, embora haja um discurso entre os profissionais de busca pela garantia da integralidade do cuidado por meio de uma prática pautada em conhecimentos interdisciplinares, as intervenções se restringem a um universo de possibilidades muito restrito e cristalizado. As intervenções frequentemente seguem um 
protocolo em que constam intervenções medicamentosas seguida de encaminhamentos para as especialidades ou o encaminhamento para grupos terapêuticos realizados na própria UBS.

\subsection{Como os profissionais se relacionam com o adoecimento mental}

Durante os grupos focais, os profissionais falaram sobre o medo diante de uma situação desconhecida e de não ter conhecimento suficiente para lidar com a loucura. Além disso, reconhecem a própria vulnerabilidade diante do risco de adoecer.

O desconhecido, eu acho que assusta, né? [...] Então, eu acho que essa coisa do desconhecido vai te levando a não enxergar aquilo, né? A não entrar em contato com aquilo que... [...] E... aí engessa, eu acho que a tendência é você engessar e sempre ficar muito... porque tem um monte de outros protocolos que você foi formada pra ver... (Mirian, nutricionista)

Então, mas será que eles não querem lidar com a Saúde Mental? Porque eu acho que eles não conseguem, porque eu acho que é tão difícil que eles afastam, assim... eu não sei o que fazer... então... se afastam [...] Eu acho que a loucura, ela assusta porque ela é muito assim... tá longe isso, mas quando você vê na sua comunidade, seu vizinho, né? E fala, nossa... será que is so pode acontec er comigo? (Fabiana, terapeuta ocupacional)

Antigamente, eu tinha medo de lidar com Saúde Mental [...] morria de medo. Eu não sabia como lidar [...] medo da loucura, assim... e dos pacientes também, dos ditos loucos é... esquizofrenia, por exemplo, que é o característico da loucura. Hoje em dia, estou aprendendo a conhecer, aprendendo a lidar... (Marta, enfermeira)

Algumas falas expressam diferentes valorações sobre situações que envolvem o adoecimento mental. O caso da dependência química é um exemplo disso. A agente comunitária de saúde Maria discorre sobre isso: "Eu lido até com drogado, mas com bêbado, eu chuto a bunda dele mesmo. Tá caído mesmo lá no chão e vai ficar, nem olho”.

Diante dessa situação os profissionais se questionam sobre o que fazer quando se deparam com o adoecimento mental. Falam sobre os sentimentos de surpresa, de invalidez, de impotência e de fracasso e de quando "a gente chora".

Pra gente, às vezes, é até uma surpresa porque você conhece aquela pessoa e, de repente, você chega um dia, num dia de visita, na casa da pessoa e a pessoa está lá surtada, né? Totalmente descompensada... eu já presenciei cadastrada minha sair amarrada porque...porque tinha pirado. Então, às vezes, é um choque pra gente, mas conforme a gente vai conhecendo nossos cadastrados, a gente vai conseguindo detectar, né? [...] Então foi um choque, mas sempre é um choque pra gente... (Maria, ACS) 
A ACS destaca que o convívio com as famílias permite que ela conheça as pessoas, no entanto não relata a observação de riscos, de processo de adoecimento, mas sim o surto, algo que ocorreu "de repente", que "chocou", fala sobre a ruptura de comportamentos que tornaram o adoecimento um caso de polícia, já que a pessoa saiu "amarrada".

Os profissionais dizem que os casos atendidos no campo da Saúde Mental têm algumas especificidades:

é diferente de outras patologias, de outras doenças crônicas. Então, o paciente é hipertenso e não adere, então, se faz um trabalho com ele e o tratamento... Toma medicamento, tá controlado. O paciente de Saúde Mental, invariavelmente, ele entra em crise e tem uma dificuldade maior pra aderir... Então, eu acho que vai apontando, também, muita impotência na equipe, porque por mais que eles invistam, o que não é difícil esse investimento, ele sempre cai no vazio. [...] Acho que isso vai trazendo uma frustração pra eles, muito grande... (Julia, psicóloga)

Eu acho que é diferente porque a gente fica muito abalada com o problema da pessoa [...] mexe muito com o emocional da gente. Às vezes, a gente chega em casa... Não só na reunião de equipe, a gente leva até pra casa, muitas coisas. (Rosa, ACS)

Porque, às vezes, têm coisas que... principalmente o mental. Sabe por quê? Porque a gente se sente é... inválida, impotente, inválida, não sabe o que fazer. Manda pra um lugar e não dá certo, manda pra outro lugar e não dá certo. (Maria, ACS)

Essas ideias estiveram fortemente presentes nos grupos focais. Os profissionais, de uma maneira geral, parecem identificar o adoecimento mental como uma condição diferente das demais patologias, na qual a pessoa com transtorno mental "não adere" e a equipe tem a sensação de "impotência" e de que suas ações "caem no vazio".

Essas falas expressam a dificuldade não apenas relacionada à atenção à saúde da população, mas também sobre o sofrimento gerado ao entrar em contato com o adoecimento mental e com os próprios sentimentos. A sensação de impotência e a frustração diante dos resultados obtidos no cuidado em Saúde Mental ficam explícitas.

\subsection{A prática: propostas, ações e principais dificuldades}

\section{Sobre as ações}

No primeiro grupo focal, o médico da equipe nos oferece um panorama sobre como costumam proceder diante de um caso de Saúde Mental: 
Nesse caso o trâmite é o paciente passar esse caso pro agente de saúde, em visita domiciliar, e o agente de saúde, em reunião de equipe, ou em contato com o médico e com a enfermeira. Aí depende do paciente, o que ele tá sentindo, como tá interferindo na vida da pessoa... e, dependendo da gravidade, a gente pode estar indo na casa do paciente, a gente pode estar agendando uma consulta de encaixe, sem precisar a pessoa esperar muito tempo por isso. E nessa consulta ou nessa visita domiciliar a gente vê o que pode estar fazendo pela pessoa. É importante, também, passar esse caso, discutir esse caso com o NASF, né? O NASF tomar conhecimento e estar ajudando a equipe no que pode ser feito em relação àquela pessoa. Alguns casos são mais complicados e precisam de uma avaliação um pouco mais especializada, no caso do CAPS, e essa ponte com esse setor é feito pelo NASF. (Valter, médico)

Nesse trecho é possível observar que as ações seguem um determinado protocolo de atendimento que parece organizar o cuidado por níveis de complexidade. O desenrolar das intervenções parece estar relacionado à gravidade do caso: quanto mais grave, maior a necessidade de um cuidado especializado.

A expressão "passa o caso", apresentada pelo médico, é utilizada com frequência durante as reuniões de equipe, e nesta fala em específico nota-se que há uma oscilação entre "passar" o caso ou "discutir". Apesar disso, a ideia dos encaminhamentos é retomada, parece que cada instância "passa o caso" para outra que, supostamente, terá melhores condições para atender. O usuário não parece participar da construção de seu projeto terapêutico.

Contudo, há falas que explicitam que, apesar de haver um determinado fluxograma, existem situações que exigem uma postura ativa do agente de saúde ao se deparar com uma emergência. Mesmo assim é prevalente a ideia do encaminhamento. A ACS Maria esclarece: “Às vezes a gente tá na rua e diante dessa situação o que... que a gente orienta? Ah... hospital ou CAPS?"

Em seguida surgem outros comentários sobre as ações que os agentes comunitários de saúde desenvolvem ao se deparar com uma situação de adoecimento mental:

Não, no primeiro momento a gente quer escutar ela. Daí a gente escuta, a pessoa chora, desabafa. [...] A gente escuta, fica escutando o que ela tá vivendo, o que ela tá passando pra gente. Daí que vêm nossas orientações. (Maria, ACS)

Nessa fala a escuta aparece como um elemento importante, porém parece que ela não é considerada uma intervenção, e sim um meio para que algo seja feito: "Daí que vem nossa orientação". 
No primeiro grupo focal os profissionais contam um pouco sobre o fluxograma das ações em Saúde Mental; já no segundo encontro eles falam sobre ações mais específicas como, por exemplo, o grupo de mulheres:

Teve um grupo de mulheres, que assim... chega uma senhora...chegou uma senhora pela primeira vez e ela começou a falar que ela ficava nervosa e vomitava... mas uma senhorinha assim... fora do estereótipo do grupo de mulheres, né? E assim... Com uma vida organizada... sem histórico de depressão, de transtorno mental, um sofrimento normal. Ela ficava nervosa e vomitava e isso trazia um incômodo. E foi uma sessão que o grupo foi muito power, muito pesado, as mulheres num sofrimento de alucinação de... sei lá, tentativa de suicídio... (Julia, psicóloga)

E fora que esse grupo é um grupo para demandas leves. E a maioria é de mulheres com transtornos mentais e aí... (Mirian, nutricionista)

Mas... assim, qual é a nossa prioridade? Porque, de repente, ouvir e cuidar dessa senhora que vomita quando tá nervosa também seria uma prevenção para algo maior, né? (Julia, psicóloga)

O diálogo apresentado expressa uma preocupação trazida pelos profissionais também em outros momentos. Estes dizem que, muitas vezes, uma ação estruturada para ser uma intervenção de prevenção acaba sendo dirigida a uma população que já se encontra adoecida, pessoas que já têm "transtorno mental", "tentativa de suicídio", ou seja, os casos mais graves.

Essa situação permite pensar sobre as possibilidades reais de intervenções das equipes, pois nos prontuários também foi possível verificar tentativas, como encaminhamentos para grupos realizados na UBS, mas fica a impressão de que as intervenções não são singulares, is to é, que os encaminhamentos acontecem a partir de um “cardápio" de ações já prontas.

$\mathrm{Na}$ situação descrita acima sobre a "senhorinha", a equipe avalia que ela demandaria uma intervenção de prevenção, mas mesmo assim foi encaminhada a um grupo de pessoas com problemas "mais graves".

Além do grupo de mulheres, os profissionais falam sobre outras atividades desenvolvidas e que consideram relacionadas ao campo de intervenções em Saúde Mental, como os grupos de atividades físicas, de fisioterapia e de artesanato.

A nutricionista conta que procuram fazer com que as pessoas com transtornos mentais ou em risco de adoecimento possam participar de atividades diversificadas, que possam circular por espaços que não estritamente os da Saúde Mental. Esc larece que essa tentativa está relacionada à necessidade de diminuição do estigma relacionado à loucura. 


\title{
Sobre as principais dificuldades
}

A partir da exposição do que os profissionais apresentam como propostas de intervenção, eles passaram a relatar, também, as principais dificuldades relacionadas ao atendimento no campo da Saúde Mental.

\begin{abstract}
Na Saúde Mental o que acontece... No caso de hipertensão e diabetes você tem uma aferição de pressão, você tem um exame de glicemia que pode te ajudar a excluir aquele diagnóstico, né? Já na Saúde Mental você não tem necessariamente um exame laboratorial que vai te dar aquela medida... a fazer aquela medicação. Então, muitas vezes, você precisa de uma sensibilidade um pouquinho mais... hum, mais... aumentada (Valter, médico)
\end{abstract}

Usar medicamento, não usar medicamento? Qual medicamento? Precisa de psic oterapia? Precisa de uma conversa? Essa conversa é só com aquela pessoa? É com a família? Quem da família você vai conversar? Tá influenciando no trabalho daquela pessoa ou não tá? É uma coisa que você precisa acompanhar muito tempo pra você perceber uma melhora. Melhorou ou não melhorou? Troca medicamento ou não troca medicamento... Tá indo no CAPS, tá fazendo terapia? Não tá, por quê? Então, muitas vezes, chega a dar, realmente, uma sensação, que nem a Maria falou de... de impotência. Em alguns pacientes você não tem realmente o que fazer, apesar de estar medicando, de estar fazendo terapia, de estar acompanhando em alguma outra... outra... algum outro serviço. Mas você... você passa um mês ou um ano e você não vê aquela melhora substancial que deveria acontecer. (Valter, médico)

Então, a dificuldade de trabalhar com essa questão de saúde mental é essa, você não... o retorno que você espera de ter de um caso, você acaba não tendo. Então, isso é muito complicado [...] Toda a equipe se mobiliza, vai à casa, liga pra... liga pra um, liga pra outro. Entra em contato com o CAPS, entra em contato com o NIR [Núcleo Integrado de Reabilitação], tenta fazer todo um movimento e aquilo ali não dá em nada. É o que aparenta, né? (Marta, enfermeira)

Os profissionais parecem ter dificuldade em ver a melhora das pessoas atendidas. Quando a medicação, o exame e as orientações sobre hábitos de vida não são suficientes para o alcance da melhora esperada, os profissionais expressam ter dificuldades no desenvolvimento de ações. Quando só o remédio ou a orientação não garantem a melhora esperada, surge a sensação de impotência. Na realidade, é de se supor que nas demais situações de adoecimento esses profissionais têm a ilusão de obter o resultado esperado de suas ações, por conta de protocolos mais objetivos para a intervenção em doenças como a hipertensão ou a diabetes, por exemplo.

Os profissionais, ao falarem sobre algumas dificuldades, discorrem sobre o perfil das pessoas que atendem, refletindo sobre o próprio trabalho: 
Eu não sei, acho que isso tem a ver com ferramentas mesmo, não sei se disponibilidade ou se a pessoa tem esse recurso pra lidar [...] é um estigma muito grande, né? É um preconceito... [...] Então, parece que é um paciente que é uma bomba-relógio, pode explodir a qualquer momento e... eu não quero estar por perto. Essa é a sensação das pessoas e... tem, acho que a Saúde Mental tem sim esse desvio da normalidade que... do comportamento aí, que afeta todo mundo, e tem aqueles que gritam e que ficam mais agitados e aqueles que, por outro lado, são os quietinhos, os deprimidos... e que não chegam... (Fabiana, terapeuta ocupacional)

A fisioterapeuta concorda com o que foi dito, esclarecendo que alguns casos não recebem atendimento porque "não chegam... não estão incomodando, de certa forma...":

Aí tem outra coisa. Será que só chega pra gente o que incomoda? Será que o olhar não está muito mais focado em cuidar de quem grita mais e de quem aponta o erro da equipe de saúde, né? Porque assim, ele tá deprimido dentro de casa e ninguém tá vendo, mas a partir do momento que foi pra escadaria e gritou que era Iemanjá, a comunidade se mobiliza e aí aponta as falhas do serviço de saúde. (Julia, psicóloga)

E até que ponto esses pacientes que são mais deprimidos, que ficam mais limitados ao lar, isolados, ficam na doença e só chegam quando, de repente, tem uma tentativa de suicídio... Aí sim, aí vem pra gente, aí vem pra preocupação... (Denise, fonoaudióloga)

É... mas eu não sei se tentar promover a saúde é algo que é aprendido na faculdade ou outra formação... Sim, tem que ter o embasamento teórico, mas acho que... quando eu falei da disponibilidade, é de cada um estar apto e conseguir se dedicar, conseguir cuidar, conseguir pensar estratégias de promover o cuidado, de fazer uma promoção de saúde. Então, acho que vai além da teoria. (Adriana, fisioterapeuta)

Os profissionais falam sobre o perfil das pessoas que atendem: são aquelas que incomodam, "gritam", apresentam alterações de comportamento, desvio da normalidade ou quando tentam suicídio. Ou seja, parece haver dificuldade em diagnosticar e intervir em situações de risco, e as ações acontecem quando não há mais para onde correr, quando as pessoas reclamam por atendimento. Há pouco espaço para se fazer o que de fato é preconizado: a promoção de saúde e prevenção do adoecimento. O que é interessante notar é que neste grupo focal a dificuldade é apontada como algo localizado nos profissionais da ESF, e não no NASF.

O grupo parece acreditar que os poucos recursos da comunidade e a dificuldade de articulação da saúde com outros setores são determinantes para a dificuldade no estabelecimento de ações que tenham como foco a prevenção do adoecimento e a promoção da saúde. 
Então, eu acho que a gente tá aqui, então, fingindo que tá aqui pra fazer apoio, quando na verdade a gente faz sim... tenta cobrir um buraco da rede que é de assistência, né? [...] Como que você vai fazer promoção da saúde se você não consegue dar conta da assistência? Então, eu acho que é isso, não dá pra gente fingir que não precisa fazer assistência [...] O que é o cuidado pro paciente de Saúde Mental? Que é uma coisa que a gente discute muito na Jornada. Porque, às vezes, a gente fica esperando a cura, que é a transformação total daquele indivíduo pros padrões de normalidade. Quando, na verdade, a gente que trabalha mais intensamente com alguns pacientes, reconhece que esses pequenos ganhos, diante do objetivo ali com aquele paciente. [...] porque o que é efetivamente uma ação de promoção à saúde mental? Em um território como esse com pouquíssimos recursos... (Mirian, nutricionista)

É isso que eu estava pensando, essa questão de promoção vai muito além do que a gente faz porque envolve outros setores, outras instituições, de... de educação, de moradia, cultura... Então, como você fala que o cara tá bem se ele não tem casa, se ele está desempregado, se ele tem uma série de problemas que vão desencadear em um sofrimento muito grande e ele não vai saber lidar com isso. Eu acho que é muito maior, um exemplo clássico que eu acho que todo mundo usa: como você vai tratar uma diarreia com um esgoto a céu aberto do seu lado e não tem como resolver aquele problema, né? Não adianta por um monte de vitaminas ali para ele tomar porque o problema continua ali. Então, eu acho que é um problema muito maior, acho que é uma questão social mesmo. Até mesmo o conceito de saúde, o bem-estar biopsicossocial, né? Então, passa por tudo isso, acho que não é só a saúde, acho que passa por todas as questões mesmo sociais que envolvem... (Adriana, fisioterapeuta)

Que nem ela fala de prevenção, eu acho que não é só a gente da saúde, ou eu que sou auxiliar e vocês que são do NASF, tinha que ser todas as áreas, tipo na segurança, na área da educ ação... (Ligia, auxiliar de enfermagem)

A partir disso, os profissionais falam sobre a fragilidade da rede de cuidados especializados em Saúde Mental. As dificuldades, de um modo geral, parecem estar relacionadas à complexidade envolvida na formulação do diagnóstico e no tratamento da doença mental, que diferentemente de doenças que envolvem aspectos físicos, não contam com o auxílio de exames laboratoriais e de suporte medicamentoso que garanta a cura.

É porque tem coisas que não estão ao nosso alcance, que seriam outros níveis de trabalho, de processo e... aquele processo, aquele serviço... a gente não dispõe, é o caso da psiquiatria, por exemplo. (Valter, médico)

$\mathrm{Na}$ fala abaixo, as dificuldades parecem estar ligadas também na identificação da gravidade e na realização do encaminhamento adequado para o serviço especializado em Saúde Mental:

Porque fala assim que ele é porta aberta, né? Olha, o CAPS é porta aberta. Tá, é porta aberta. A gente tá vendo um aí, por exemplo, o Sérgio, não era o 
caso de hospital... porque ele tava bem deprimido, chorava muito, tá? E... foi, foi o doutor que atendeu, né doutor? Mas foi na... não tinha ninguém do NASF. O que que a gente fez, mandamos pro CAPS, então o CAPS acolheu, a Tereza [psicóloga do CAPS] lá acolheu... só que depois mandou pro posto. Então, a gente fica... [...] Então, a gente tá meio perdido, entendeu? (Elisa, ACS)

Os profissionais parecem estabelecer uma relação entre o adoecimento mental e as condições de vida das pessoas, comentando que há situações de vida que causam sofrimento. A psicóloga complementa, questionando: "qual o impacto que essas coisas também trazem pra Saúde Mental dessas pessoas?”. A nutricionista se propõe a refletir sobre isso: "Eu acho que a gente ouve histórias aqui que eu acho que... até tem um sofrimento comum, mas muito pesada...”. E, diante dessa discussão, os profissionais afirmam que poucas vezes são solicitados a auxiliarem no cuidado de "sofrimentos comuns" e, quando são requisitados, "você está com um caso mega cabeludo, você vai dar atenção pra menininha que terminou o namoro?" (Fabiana, terapeuta ocupacional).

Parece que as equipes de Saúde da Família estão comprometidas com a pessoa adoecida muito mais do que com a promoção da saúde ou prevenção do adoecime nto. Não é possível que os profissionais voltem a atenção aos sofrimentos relativos ao cotidiano, quando têm a responsabilidade de atender aos casos "mega cabeludos".

O grupo aponta também os obstáculos para o estabelecimento de um cuidado à família:

\begin{abstract}
É que a gente, também, não está preparada pra tratar a família. Por mais que a gente conviva com isso no dia a dia. Falta um pouco de técnica de como fazer isso, tratar a família toda. Eu percebo isso, acho que o pessoal da equipe também, né? E, geralmente, a gente tem aquela coisa: Ah, vamos tratar o sujeito, daí vem toda aquela outra questão que a gente consegue perceber, mas não sabe por onde começar... (Daniela, terapeuta ocupacional)
\end{abstract}

\title{
Sobre a rede de cuidados em Saúde Mental
}

A articulação da rede de cuidados em saúde é uma das funções da ESF e do NASF. Tal atribuição tem como objetivo viabilizar a integralidade do cuidado, bem como facilitar o acompanhamento e corresponsabilização entre os diferentes serviços pelos quais a pessoa com transtorno mentalé atendida.

Os profissionais, durante as reuniões de equipe, queixaram-se da fragilidade da rede de cuidados em Saúde Mental. Afirmam que há precariedade da rede, esclarecendo acreditar que o número de psiquiatras e a quantidade de serviços especializados são 
insuficientes para o atendimento da demanda do território. Fica claro que identificam o problema na pouca quantidade, e não na qualidade de atendimentos.

Por outro lado, os profissionais do NASF, ao discutirem sobre essa questão no segundo grupo focal, apresentam outra percepção sobre a articulação da rede. Apontam a periodicidade mensal de reuniões com serviços especializados em Saúde Mental Ambulatório, CAPS AD e CAPS Adultos - como um avanço nas possibilidades de comunicação da rede de cuidados. Contudo, afirmam que esses espaços ficaram, por muito tempo, tomados por discussões relacionadas à definição de critérios para o atendimento em cada nível de complexidade.

Porque têm alguns momentos, acho que a gente teve dois momentos com o CAPS, teve essa mudança de gestão, né? Em alguns momentos era uma coisa, muito de ir pra reunião do CAPS e.... brigar pra que o paciente fosse atendido lá, né? Tinha sempre aquela briga: Olha o paciente não tem perfil de CAPS, o paciente tem perfil de CAPS... era uma coisa do tipo: toma que é de vocês, vocês que cuidem aí. Então, a gente ia para as reuniões, muito mais para defender os direitos do paciente de acessar o serviço do que para pactuar o cuidado. Então, acho que era muito pesado, para os outros profissionais, que não eram das categorias de Saúde Mental, participarem desses espaços. E aí, eu fico pensando mesmo, na equipe de saúde que tem que entrar nesse embate de identificar o que é paciente de CAPS e o que não é, né? Graças a Deus, eu acho que isso melhorou, houve mudança de gestão... [...] Eu acho que nas últimas reuniões a gente tem conseguido discutir mais o que é o cuidado... Que etapas fazem parte do cuidado do paciente de Saúde Mental? O que é feito no CAPS? O que pode ser feito na UBS? Quais são os papeis que cada profissional pode ter, né? Nesse processo todo... Eu acho que teve uma evolução, mas foi muito sofrido. (Mirian, nutricionista)

A nutricionista nota uma melhora em relação à qualidade das discussões entre os profissionais e parece relacionar a mudança de gestão a esse fato. Questões relacionadas à gerência e à organização do trabalho aparecem nesse grupo focal como elementos muito importantes para a viabilização do trabalho interdisciplinar.

Diante dessas observações, a fisioterapeuta chama a atenção para uma questão relacionada às possibilidades de realização da interdisciplinaridade nos espaços de articulação dos serviços da rede:

Qual é a função dessas reuniões da rede? Qual a finalidade dessas reuniões? É discutir a técnica, a especialidade? Então, a queixa é em reabilitação física, é de fisioterapia? Então vai fisio discutir com fisio? No CAPS vai a psicóloga, vai a TO, vai discutir a técnica ou vai discutir o cuidado, o paciente? Porque se for pra discutir o cuidado com o paciente, tem que ter alguém da Estratégia lá. E não somente alguém do NASF, né? Então, qual é a finalidade dessas ações? (Adriana, fisioterapeuta) 
A participação nas reuniões fica restrita aos profissionais do NASF, o que limita as possibilidades de estabelecimento de trocas de saberes e experiências, já que o diálogo se estabelece com um grupo de profissionais especializados em determinados campos de saber, pois geralmente quem vai às reuniões com os serviços de Saúde Mental são a psicóloga, a terapeuta ocupacional e a assistente social, profissionais já bastante familiarizadas com as questões do campo.

A fisioterape uta chama a atenção para a questão de como se desenvolvem as ações conjuntas entre os serviços de saúde. Os espaços de reuniões são garantidos, no entanto os encontros parecem ficar fortemente ligados às discussões feitas apenas entre os especialistas sobre as técnicas e sobre os encaminhamentos. O espaço para a discussão do cuidado sob os diferentes pontos de vista para a elaboração de projetos terapêuticos é restrito.

Durante as observações de reunião de equipe, foi possível notar que os profissionais do NASF, como apoiadores, apresentam clareza sobre essa questão e, diante disso, tentam minimizar os efeitos da não participação dos profissionais da ESF nas reuniões com a rede, colocando-se como interlocutores entre es sas equipes.

Essa situação pôde ser observada em uma das reuniões em que a nutricionista e a psicóloga relatam uma reunião de articulação junto aos profissionais do CAPS. Em seguida, informam à equipe de Saúde da Família sobre algumas reestruturações a serem implantadas no funcionamento de tal serviço, propondo uma discussão acerca dos motivos de tais mudanças, como a necessidade de expansão de atendimentos para além daqueles relacionados ao atendimento psiquiátrico e medicamentoso.

Outro aspecto importante sobre a rede de cuidados refere-se ao fato de que são raras as articulações com serviços que não sejam de Saúde Mental, o que compromete as possibilidades de realização da integralidade do cuidado.

\section{Sobre o Apoio Matricial}

Ah, o matriciamento é quando a gente começa a colher histórias, quando... vamos supor... Igual eles fizeram mesmo, né? Eles falavam umas coisas, a gente falava outras e eles foram escrevendo e a gente foi juntando algumas coisas, algumas informações, formando... aí saiu alguma coisa sobre a Marlene [...] Que começou a abrir mais a nossa mente. (Maria, ACS)

Aí o pessoal do NASF começou a explicar o que era transtorno bipolar, o que era depressão, o que é mania. Quando você tem uma dúvida, será que isso é depressão ou não é? O pessoal do NASF ajuda a dar algum indício sobre o que é diferença de uma depressão pra uma tristeza, que não é uma... 
que não é uma depressão. [...] E quando você tá com um caso, por exemplo, você traz um caso, a gente tá discutindo um caso e o pessoal do NASF fala: "Ah, a gente pode fazer isso e isso e isso. Vocês podem fazer assim, assim e assado". (Marta, enfermeira)

Ao discutirem sobre o Apoio Matricial, os profissionais dizem ser um momento de aprendizagem, de trocas, de esclarecimentos sobre dúvidas e, até mesmo, de discussão de casos e de elaboração de projeto terapêutico, mas parece que é uma via de mão única, na qual apenas o NASF esclarece, explica, diz o que fazer.

$\mathrm{Eu}$ acho que o NASF veio com um objetivo e em nenhum lugar ele acaba funcionando direito como está na portaria. Porque se as reuniões de equipe funcionassem mesmo como espaço de matriciamento para a gente discutir o caso e tentar resolver um caso só naquela reunião, né? Mas a demanda da equipe é muito grande, então, eles querem passar o caso mesmo pra gente, né? E, muitas vezes, acaba não dando tempo de discutir, até por uma questão de angústia mesmo, né? Por conta das famílias que o Valter falou. Agora, se desse para discutir um caso, eu acho que a resolutividade iria ser maior, mesmo que fosse demorar mais, porque quando a gente discute, todo mundo junto, um caso só, dá pra gente dividir as funções, as tarefas... cada um faz uma coisa. Entender, também, pra que serve o CAPS, que tipo de paciente que vai pra lá, né? (Daniela, terapeuta ocupacional)

No trecho apresentado, a terapeuta ocupacional explica que o matriciamento, como consta na portaria, é uma ferramenta importante para a discussão de caso, elaboração compartilhada da intervenção em Saúde Mental e para a compreensão sobre o funcionamento dos serviços especializados. No entanto, ela atribui a angústia dos profissionais da ESF diante das famílias que solicitam intervenções imediatas e o número excessivo de casos como barreiras para o desenvolvimento efetivo do Apoio Matricial.

No segundo grupo focal, os profissionais afirmam que:

o matriciamento ainda é o maior nó. Porque... envolve aquilo tudo que a gente falou, né? Em que momento alguém chegou e falou: "matriciar é assim"? Existe um senso comum? Senso comum é o que eu falo: existe uma concepção, um padrão? Todos devem fazer assim? Ou fica no subjetivo? Isso é o maior nó. Não só pra Estratégia como pro próprio NASF, né? Eu acho que aí vai refletindo no processo, vai refletir no PTS, vai refletir em todos os demais, né? (Adriana, fisioterapeuta)

Eu acho que quando você chega a estar nesse momento... apesar de estarmos aqui institucionalmente, né? Por ser uma política, né? Uma política não, mas uma estratégia... ainda assim fica tudo na ordem da boa vontade... Eu acho que o Apoio Matricial e a elaboração do Projeto Terapêutico, três anos depois da implantação do NASF, começa a ganhar mais força agora. Eu acho que as equipes que entraram tiveram tantos processos, assim, pra passar, que eu acho que no começo valorizava-se muito mais a ação efetiva com o paciente do que com a equipe de saúde. 
Acho que são os dois focos de ação do NASF, a equipe de saúde e o paciente. A primeira geração do NASF tinha um foco muito forte pro paciente, pra dar conta da demanda... e esquecia-se muito da capacitação com as equipes, né? E eu acho que agora, três anos depois, a gente revê isso e começa a pegar isso mais forte, tanto que aqui a gente criou esse espaço separado [Jornada de Clínica Ampliada] pra exercitar a execução do Projeto Terapêutico Singular. (Mirian, nutricionista)

Os profissionais apontam que a realização do Apoio Matricial ainda é um desafio, embora percebam que obtiveram ganhos com relação à possibilidade de realizarem capacitações para as equipes, além da realização de atendimentos com as famílias. Os profissionais atribuem a dificuldade em realizar o matriciamento a um desconhecimento, ausência de uma formatação para essa ação, o que acaba gerando o que tantas vezes foi relatado no grupo focal: a "dependência da boa vontade". Pela primeira vez a dificuldade também é percebida como algo que não envolve apenas os profissionais da ESF, mas também os do NASF.

A auxiliar de enfermagem comenta que não tem oportunidade de participar dos momentos de matriciamento, pois no horário das reuniões ela permanece na coleta de exames e, nos horários de Jornada de Clínica Ampliada, também é convocada a participar de outras atividades, o que gera uma defasagem com relação ao conhecimento dos casos e dos projetos terapêuticos formulados.

Olha, assim, eu falo por mim, tem uns casos na minha área que eu não consigo entender o que está acontecendo, o que ele está fazendo de atividades, não sei o que o NASF tá fazendo, não sei o que o médico ou enfermeiro está fazendo, entendeu? Eu só sei assim... por exemplo, caso Matheus. Eu sei quem é o Matheus. O caso mesmo, só sei disso, entendeu? Eu não consigo ir na reunião, assim... aí... eu falo: falta um pouco de... eu preciso saber, eu preciso conhecer, mas eu não consigo. Meu tempo é diferente até mesmo da enfermeira ou do médico. A gente... eu sei que tem o meu horário de reunião, mas é como ela falou, 9 horas da manhã, eu estou lá na coleta e eu tenho que dar prioridade porque lá também tem um horário e além de mim tem as outras pessoas. Quando eu chego na reunião é 15 pras 9 ou já é 9 horas, já não tem mais ninguém, já finalizou o caso. Então, eu chego e falo: "Gente, eu quero saber o que...", e respondem: “Ah, eu não aguento mais". Porque já foi tão discutido que o pessoal não consegue mais passar. Eu fico nos bastidores. Teve uma vez que eu até fui na reunião, tava um pessoal do CAPS e sabe quando você fica viajando nas histórias? Ah, porque ficam falando tal coisa, tal coisa... você não sabe realmente o que aconteceu. A mãe dele é isso, a mãe dele é aquilo... (Ligia, auxiliar de enfermagem) 


\section{Sobre a Jornada de Clínica Ampliada}

Como dito anteriormente, esse espaço foi criado estrategicamente pelos profissionais do NASF para viabilizar a realização do Apoio Matricial.

Os profissionais dizem que a Jornada foi importante como momento de aprendizagem e de trocas de experiências que possibilitaram a transformação de olhares sobre os casos de Saúde Mental do território. Relatam que, a partir das discussões, eles puderam compreender melhor o processo de adoecimento mental.

A equipe também apresenta uma visão positiva desse espaço estratégico afirmando que:

A Jornada é um espaço bacana em que a gente consegue falar de um monte de outras coisas, a gente tenta ampliar pra discussão sobre temas, teve uma equipe que a gente leu o Caderno [Cadernos de Atenção Básica: Diretrizes $N A S F]$ e foi bem bacana porque no Caderno eles falavam do sujeito singular, eles ficavam supercuriosos pra entender essa história do que é o sujeito singular... E aí era super legal porque eles entendiam, né? Eles tinham entendido o que era... (Mirian, nutricionista)

Conseguiam articular a prática com aquilo que a gente tava lendo, né? (Fabiana, terapeuta ocupacional)

Foi muito produtivo, e na reunião de equipe, parece que é um momento muito à parte, é conduta, conduta. (Mirian, nutricionista)

Vamos estabelecer condutas e não vamos discutir, trocar. É muito prática. $\mathrm{O}$ que, pra esse caso, a gente tem que fazer? Então, vamos estabelecer metas, mas é isso, é difícil. (Fabiana, terapeuta ocupacional)

A nossa dificuldade é, hoje, não que a Jornada tenha esgotado, né? Transpor esse momento da Jornada pra reunião de equipe. (Mirian, nutricionista)

A gente escuta: "Ah, mas eu não consigo perceber uma resolução do caso". $\mathrm{E}$ isso não é o que a gente espera da Jornada, a gente espera o teste da ferramenta que é o Projeto Terapêutico, a gente quer que eles ampliem o olhar e utilizem essa ferramenta do PTS, durante a reunião de equipe. Então, eles precisam aprender a utilizar... (Miguel, educador físico)

Interessante observar que os profissionais do NASF parecem ter estruturado um espaço para as discussões de casos e para as capacitações, mas não se preocupam com o resultado das intervenções clínicas. $\mathrm{O}$ interesse dessa equipe está no desenvolvimento das discussões e no processo de trocas e de aprendizagem envolvidos nesse espaço. Por outro lado, parece que tudo o que os profissionais da ESF querem são bons resultados das intervenções clínicas, querem "resolver". No grupo focal não foi dito nada sobre um espaço para que as equipes pudessem conversar sobre essa diferença de expectativas. 
No trecho abaixo, os profissionais falam um pouco sobre serem testados pelas equipes de Saúde da Família, sobre serem questionados em relação aos seus conhecimentos e capacidades. Isso é importante, pois fala sobre a relação de confiança, fundamental para a prática da interdisciplinaridade. Além disso, os profissionais comentam que a população e os próprios profissionais da ESF querem sempre os cuidados de especialistas, na esperança de que estes saibam o que fazer. Os insucessos parecem ficar relacionados ao não conhecimento/capacidade daquele que atende, por isso pensam em mudar as referências, os profissionais.

Hoje eles já conseguem ver de uma forma diferente, mas é um trabalho de sete meses, oito meses. Então, eu acho que vem disso, também, o quanto eu quero aceitar o que ele está falando pra mim e acreditar no que ele fala pra mim? Dar credibilidade. Porque a gente passa por esse processo de credibilidade pelos outros profissionais pra gente poder fazer esse apoio matricial no momento de reunião de equipe. (Miguel, educador físico)

Tem vezes que eles pagam pra ver, né? Por exemplo, eles querem a psicóloga e está marcado pra TO, eles falam meio que: "Ah, vamos lá, vamos ver se ela é boa mesmo, mas a gente pode aceitar ela nos nossos casos..." (nutricionista, Mirian)

Na Saúde Mental, né, Mirian? Isso é forte. Aconteceu isso com a nossa equipe, a gente teve o caso do Iago, que teve uma movimentação e uma troca de referência... e que a Mirian foi uma dessas, mas a gente entrou na frente, a gente não precisa trocar ou por uma outra pessoa nessa referência, que é um caso de Saúde Mental, porque quem vai lá é o Miguel e não tem necessidade da gente fazer a troca. Se mais pra frente existir uma limitação desse profissional, a gente pode acrescentar um outro profissional ou trocar. Então, essas... é nisso que eu acho que a coisa se atravanca, para, trava... precisa ver se a equipe está disposta a aceitar isso. A categoria do profissional não é a que eu quero: "Ah, mas ela precisa de uma psicóloga porque ela me falou que quer passar com uma psicóloga, que ela não pára de chorar". Você pergunta: "Ela está com dor, o quê?" Ela diz: "Não sei, ela não para de chorar..." (Miguel, educador físico)

\section{Sobre o Projeto Te rapêutico Singular}

O PTS é um instrumento muito importante, só que assim, é aquilo que elas falaram: a gente não tem tempo. Em uma reunião de equipe tem que se trabalhar inúmeras coisas. (Marta, enfermeira)

A gente fez um PTS, um ficava responsável pelo vínculo, o outro ficava responsável por... hum... cada um ficava responsável por uma questão do caso, né? $\mathrm{E}$ a gente ia acompanhando o caso como um todo. É... uma equipe como um todo. Todo mundo envolvido. (Marta, enfermeira)

Os profissionais alegam que o PTS é um instrumento importante para a elaboração do plano de intervenções e para a divisão de tarefas. No entanto, explicitam que há uma 
dificuldade de elaboração do projeto terapêutico, pois têm pouco tempo para a discussão, já que a reunião de equipe fica tomada por outras ações.

Dizem também que, apesar da elaboração do PTS, ele não garante que haverá melhora do paciente. Interessante notar que não relatam nada sobre a inclusão do usuário ou familiar na elaboração do plano de intervenções e metas. Pelo contrário, há uma afirmação de que a pessoa não adere, de que "dá a impressão de que a pessoa não quer se tratar".

Essa é uma questão muito importante, pois em diferentes momentos os profissionais referem propor diversas ações e que poucas vezes obtêm os resultados esperados. Relatam que encaminham para um serviço, para um especialista e, com frequência, as pessoas não comparecem às consultas agendadas.

Os profissionais, no entanto, não parecem discutir sobre o que se espera em termos de melhora, de metas.

A leitura dos prontuários possibilitou a observação de que as pessoas atendidas não participam da construção de seu próprio projeto terapêutico. Além disso, há lacunas nas informações sobre o acompanhamento, o que não permite que os profissionais tomem conhecimento das intervenções propostas pelos outros integrantes da equipe.

A análise desse material mostra que há, com frequência, um descompasso da equipe com relação a alguns procedimentos. Em um dos prontuários foi possível observar que a auxiliar de enfermagem, em visita domiciliar, não retomou a conduta prescrita pela psicóloga, oferecendo outras orientações. Parece que tal profisssional não tinha conhecimento das intervenções propostas pela psicóloga, realizando orientações sem antes discutir com a equipe, sem verificar se a usuária estava seguindo a prescrição previamente oferecida.

Esse tipo de situação evidencia algumas falhas na comunicação da equipe, o que pode gerar contradição de condutas ou até mesmo conflito para o usuário quanto ao seu projeto terapêutico. O usuário não tem clareza sobre a orientação, seguindo condutas diversas ou optando por algumas. Essa situação pode dificultar a vinculação do usuário ao serviço de saúde. No que se refere a essa situação específica, chama a atenção o fato de as auxiliares participarem muito raramente das reuniões de equipe, o que dificulta a comunicação sobre a evolução dos casos. 


\title{
4.7. A organização do trabalho
}

\section{Sobre a rotina de trabalho}

Foi possível verificar que o excesso de atividades e a dificuldade de planejamento das ações interferem nas condições de trabalho da equipe.

Durante uma das reuniões de equipe, o médico diz não ter horários na agenda e, diante disso, propõe que os atendimentos sejam marcados no mesmo horário em que deveria participar das reuniões. Parece que o momento criado para facilitar a comunicação entre os profissionais, viabilizar o estabelecimento de trocas de saberes e estruturar projetos terapêuticos pautados na interdisciplinaridade não é priorizado.

Em todo o período de observação das reuniões de equipe, foi possível notar que as auxiliares de enfermagem só participaram de uma parte de duas reuniões. Quando questionadas sobre a ausência dessas profissionais, uma das agentes explicou:

\footnotetext{
As auxiliares de enfermagem participam pouco das reuniões, elas ficam na coleta de exames, no acolhimento das emergências [...] entram de vez em quando, só para discutirem um caso específico, combinar a coleta de exames no domicílio. É difícil, porque de manhã é a hora que mais precisam delas na unidade (Maria, ACS)
}

No segundo grupo focal a auxiliar de enfermagem teve oportunidade de contar sobre sua rotina de trabalho:

\begin{abstract}
É assim, eu tenho visita toda semana, eu tenho visitas... tenho uma meta pra bater, também. E aí o auxiliar, geralmente ele vai na casa dos acamados, é... pessoas restritas, mas se não tiver pessoas assim e se eu já passei e não precisa voltar lá, eu vou em outras casas que é aparentemente normal. Uma pessoa que nunca viu a pressão, uma, uma... agente fala: "Ah, vamos comigo porque eu achei tão estranha a casa... Antes de levar um enfermeiro, vamos lá comigo pra você ver como é aquela pessoa" ou... ah, pra estar descobrindo alguma coisa, assim, alguma situação que as agentes acham de anormal elas chamam a gente pra ir ver ou se não... vamos lá na casa daquela família que é tranquilinha, né? Não tem nada, tem convênio, que só tem diabetes. E daí a gente vai fazer visita sempre. (Ligia, auxiliar de enfermagem)
\end{abstract}

A própria organização das atividades das equipes em função das metas, raramente combinadas entre os profissionais, inviabiliza a participação das auxiliares de enfermagem nas reuniões.

No trecho apresentado é interessante observar em torno de quais situações os profissionais optam por realizar a visita domiciliar. A auxiliar relata que visita as pessoas 
restritas ao lar, uma "casa aparentemente normal", ou em situações "que as agentes acham de anormal", ou ainda as pessoas "tranquilinhas". Esse não é o foco deste trabalho, mas considero importante sinalizar que é uma discussão importante que merece uma reflexão aprofundada.

\section{Sobre a burocracia e a fragmentação das ações}

A observação das reuniões de equipe trouxe elementos que possibilitaram refletir sobre a organização do trabalho e do cotidiano dos profissionais da ESF e NASF.

Durante algumas reuniões, foi possível notar que parte desta atividade ficava tomada por preenchimento de fichas e planilhas. Por diversas vezes, os profissionais pareciam alheios ao que se discutia em equipe, totalmente absorvidos pela parte burocrática de seus trabalhos.

Em um encontro, uma das agentes de saúde apresentou todas as fichas que deveriam preencher. Muitas delas traziam informações repetidas sobre o mesmo dado. Quando questionada sobre a finalidade das fichas, a agente respondeu que serviam para alimentar o sistema de informações e para controle de metas de produção.

Em reunião, uma das agentes de saúde disse:

Sabe, quando eu comec ei nesse trabalho era difícil, porque a gente entra na casa das pessoas e nos problemas delas... mas antes a gente não tinha tanta ficha, tanta coisa pra perguntar e pra orientar... agora com tudo isso a gente não tem tempo de ouvir, de escutar as pessoas. (Maria, ACS)

No mesmo dia, enquanto conversávamos após a reunião, uma das agentes comunitárias de saúde comentou: "Enquanto eles [Secretaria Municipal de Saúde] andam para frente, nós voltamos para trás, porque ficamos com mais um papel para preencher". Esse tipo de queixa é muito recorrente entre os profissionais da ESF, e alguns reclamam da falta de tempo para realizar todas as tarefas das quais são cobrados.

Eu vejo assim que eles têm cobrança de muito papel, de muita... burocracia, e aí eles esqueceram que... não, não é que esqueceram, a visão não é o dinheiro, eu falo o pessoal da alta, o pessoal da OSS, que querem ganhar mais dinheiro em cima das equipes... Com isso, eles esquecem o que realmente é o programa. Eu vejo que o Programa de Saúde da Família era pra prevenção e promoção. E dentro da promoção teriam os grupos, teria a participação dos profissionais na área, e não, simplesmente, abrir uma agenda. Agora tem uma agenda eletrônica, que eles vêm aqui, marcam e o profissional trabalha... só trabalha de terça, quarta e quinta, segunda e terça estão na flexibilidade... e os pacientes? O que eles têm a ver com isso? Aí fica aquela coisa apertada, e o pessoal se matando... Ah, quero consulta... 
Aí, o profissional não consegue nem vir na reunião, que precisa dele... (Ligia, auxiliar de enfermagem)

E a reunião acaba sendo burocrática, também. E não espaço de reflexão, né? (Fabiana, terapeuta ocupacional)

Esse discurso de que antes os agentes de saúde faziam as coisas e hoje não fazem mais, a gente escuta, também, nas outras unidades: Poxa, antigamente a a gente fazia um grupo que dava super certo, bombava... e hoje a a gente não faz mais. Eu acho que não é só aqui... (Adriana, fisioterapeuta)

A burocracia parece dificultar os encontros para as trocas de experiências e de conhecimento, assim como para a reflexão sobre as possibilidades de intervenções.

Em outros momentos, durante as reuniões de equipe, foi possível observar que a divisão das tarefas entre os profissionais ficava fortemente atrelada ao conhecimento técnico específico de cada categoria profissional, sem que houvesse uma discussão sobre os objetivos dessas intervenções e sem que houvesse participação dos usuários em sua cons trução. Essa forma de agir permite pensar que a divisão das tarefas, por esses critérios, não viabiliza a interdisciplinaridade, podendo acarretar em intervenções fragmentadas e contraditórias, o que traz repercussões importantes para o cuidado.

Em um determinado momento da reunião duas das agentes de saúde dizem que muitos de seus cadastrados relatam chegar ao balcão de recepção da UBS e serem informados de que seus prontuários foram perdidos. As agentes explicam que isso tem gerado descrédito da população com relação ao serviço. Diante disso, o médico orienta as agentes de saúde que expliquem para os cadastrados que elas não têm acesso a esses documentos e que, por isso, não sabem o que acontece. Ele acrescenta que as agentes devem pedir ao cadastrado que vá à Unidade Básica de Saúde e peça informações aos funcionários administrativos, à enfermeira, ao médico ou ao gerente. Fala para elas "passarem o pepino para frente".

A frase "passem o pepino para frente" parece expressar uma conduta frequente no serviço de saúde. A lógica do encaminhamento, tão comum nessa área, é uma versão disso. Não sabendo o que dizer ou fazer, encaminhem para outra pessoa.

Essa forma de agir parece reforçar a lógica da fragmentação do cuidado, a não responsabilização pelo acompanhamento integral, bem como agravar a situação de saúde da pessoa, que fica ainda mais fragilizada ao ser alvo de intervenções em que não é participante do processo de construção de seu próprio projeto terapêutico. 


\section{Sobre a qualidade e quantidade das ações em saúde}

Na Estratégia de Saúde da Família verifica-se que, embora seja preconizado que os projetos terapêuticos considerem a singularidade e a complexidade presentes em cada situação de intervenção, a necessidade de uma produção quantitativa parece trazer implicações para o estabelecimento das ações.

Cada profissional possui uma agenda e uma ficha de produção que deve preencher diariamente. Nas fichas constam o número de atendimentos, consultas, visitas domiciliares e grupos, entre outros.

\footnotetext{
Mas não, o pessoal quer número, número, número. A saúde não se resume a número. (Valter, médico)

É a quantidade em detrimento da qualidade. A quantidade é muito, muito, muito mais valorizada do que a qualidade. (Marta, enfermeira)

Você é o tempo inteiro cobrada por papeis, por metas, por prazos, com datas... isso acaba te... você acaba entrando na lógica do trabalho, na rotina... Então, às vezes, você não consegue perceber... Então, calma! Eu acho que é muito cobrado. Eu acho que existe uma cobrança... (Adriana, fisioterapeuta)
}

Importante observar que o tempo para realização de cada procedimento e as metas estabelecidas nem sempre são determinados pelo profissional - geralmente são estabelecidos por um gestor ou gestores. Essas fichas de produção registram números e metas a partir de uma lógica que privilegia os aspectos quantitativos e os atendimentos individuais - uma lógica que não permite o acompanhamento do processo de trabalho da equipe de maneira qualitativa.

Em uma reunião de equipe essa situação foi evidenciada pelos profissionais. $\mathrm{Na}$ ocasião, a auxiliar de enfermagem apresentou o relatório sobre o levantamento de pessoas com sintomas respiratórios, explicando que a responsável técnica pela tuberculose na Unidade Básica de Saúde havia solicitado para que as agentes comunitárias "aumentassem os números". Tal relatório apontava que a equipe havia realizado um número de orientações muito inferior às demais. Uma das agentes de saúde perguntou o que exatamente era para contar, as famílias orientadas ou as pessoas, esclarecendo que elas marcavam famílias, e não pessoas. Outra agente de saúde perguntou também: “é só número que a gerência quer" e a auxiliar de enfermagem respondeu prontamente em tom de queixa: "não importa como, mas a ordem foi de aumentar os números", complementando 
em seguida: "o que a prefeitura quer são números, o mundo está voltado para os números, e não para a qualidade de vida das pessoas".

Os profissionais se queixam, também, de serem vistos como números, sem qualidades que determinem sua singularidade. Isso pode ser evidenciado a partir da fala de uma das agentes comunitárias de saúde: "todos somos números e somos substituíveis, se o número quatro não serve, muda para o cinco, ou seis, tanto faz".

Parece que, cada vez mais, a relação entre os profissionais e entre estes e os usuários é substituída, nesses ambientes, por protocolos, fichas de atendimentos, exames laboratoriais, entre outros. Em um determinado momento, em reunião de equipe, uma das agentes comunitárias de saúde voltou-se para mim dizendo:

é... a gente fica louca nesse trabalho... é muita coisa... se a gente não ri, fica louca. Sabe, quando eu comecei nesse trabalho era difícil porque a gente entra na casa das pessoas e nos problemas dela... mas, antes a gente não tinha tanta ficha, tanta coisa pra perguntar e pra orientar... agora com tudo isso a gente não tem tempo de ouvir, de escutar as pessoas (Maria, ACS)

A valorização dos aspectos quantitativos interfere diretamente nas intervenções de cuidado em saúde produzidas pelos profissionais, especialmente no campo de produção de cuidados em Saúde Mental, que exige investimentos de diversos profissionais por longos períodos, foco na singularidade, interdisciplinaridade e intersetorialidade, considerando que o sofrimento mental, o adoecimento, é determinado por diferentes fatores presentes na vida do sujeito.

\section{Sobre a autonomia e as relações de confiança}

Eu acho assim, que o NASF, vocês não têm autonomia como tem o médico e como tem o enfermeiro. Vocês... que nem, ela não tem autonomia de, como psicóloga, dizer...eu vou resolver um caso aqui. Não, ela tem que discutir um caso com toda a equipe, aí tem que passar na mão de um, passar na mão de outro... e aí nessas, vai se perdendo os pedaços das coisas, assim... vamos supor, se está na mão da Julia e a Julia tem que fazer tal coisa eu acho que ficaria... não que tem que botar todas as responsabilidades na Julia, mas... ficaria melhor, ia ser mais efetivo, ia ter uma resolução. Que nem, a Adriana é fisioterapeuta e aí vai ficar só com a Dri, não, a Dri não tem condições, ela vai ter que mandar para um outro lugar, aí ela vai ter que esperar... não que é assim, mas a vontade da outra pessoa fazer... daí complica isso, eu acho. (Ligia, auxiliar de enfermagem)

Nesse trecho a auxiliar de enfermagem parece relacionar a autonomia no trabalho com a possibilidade de intervenção individual, de resolução do caso. As discussões de caso 
e as diferentes intervenções parecem ser apresentadas como processo em que "vai se perdendo os pedaços das coisas".

Assim, esbarra em dificuldades que são institucionais, que são limitações do próprio psicólogo, né? $\mathrm{E}$ as pessoas têm uma idealização... Até em consultório. As pessoas dizem: "Mas por que você não pode me dar um remédio?" Então, são coisas que não competem ao psicólogo, mas que eu acho que fica no imaginário da população... Quando eu entrei, acho que Dri estava comigo, uma pessoa chegou e me perguntou assim: "Você que é a físio?" Eu falei: Não, sou a psicóloga. Ah... acho que umas três cabeças levantaram e umas duas mulheres vieram falar comigo. Porque eu acho que tem isso. Ah, o psicólogo vai resolver todos os meus problemas. Então, tem implicações sim... É... mas eu acho que o que você está falando [se referindo à auxiliar de enfermagem] é a organização do trabalho do NASF... (Julia, psicóloga)

A psicóloga esclarece que existem limitações inerentes ao seu papel institucional e até mesmo restrições ligadas à sua profissão - o psicólogo não medica, por exemplo -, embora essa seja uma expectativa da população atendida. A partir disso, ela parece dialogar com a auxiliar de enfermagem explicando que alguns elementos trazidos por esta profissional, na fala anterior, como a ausência de autonomia, na verdade são características da organização do trabalho da equipe NASF.

Ao adentrarem a discussão sobre o trabalho em equipe, a psicóloga conta que em determinada reunião ela escutou uma agente comunitária de saúde falar sobre uma senhora que havia tentado suicidar-se.

Ela está fazendo atendimento psicoterapêutico particular e pode deixar que eu estou cuidando dela. É o papel da agente comunitária cuidar? É só o papel dela cuidar? É só o papel dela investigar isso. Então, olha... uma paciente que tem uma depressão severa, um histórico de suicídio na família bizarro, tentou suicidar-se... Olha que coisa pesada pra uma agente, que não vai ter nem o respaldo... É perfeito ela saber que ela é uma pessoa ativa nesse processo de cuidado... (Julia, psicóloga)

A gente tem que investigar,o quê? O que aconteceu pra ela falar: Eu vou cuidar dessa pessoa? Será que ela já tentou compartilhar com alguém e a pessoa não cuidou? Vamos dizer assim, não passou pra frente, não deu tanta atenção como ela queria que tivesse dado? Às vezes é por isso, ela pensa: Já que não vão resolver... (Ligia, auxiliar de enfermagem)

Será que isso é certo? (Julia, psicóloga)

Eu mesma já pensei: não, eu mesma vou cuidar... vai, um exemplo. Tipo, se eu for deixar na mão de fulano, de ciclano... até o próprio médico dela, da equipe... (Ligia, auxiliar de enfermagem)

Então, a equipe... Será que a equipe não está mancando? (Julia, psicóloga) 
Interessante notar que o grupo elabora uma discussão sobre as dificuldades do trabalho em equipe, os participantes começam a refletir sobre as possíveis causas para o não compartilhamento de um caso, questionam o que levaria um profissional a assumir um caso como sendo de sua exclusiva responsabilidade. Parece que concluem que o problema está na não corresponsabilização do cuidado e na falta de confiança entre os profissionais: "se eu for deixar na mão de fulano, de ciclano...".

\section{Sobre a integração das equipes}

Durante a observação das reuniões, foi possível verificar a existência de tentativas em construir projetos terapêuticos a partir da discussão de casos em equipe, bem como em realizar atendimentos compartilhados. Por diversas vezes foram agendadas visitas domiciliares conjuntas e atendimentos compartilhados.

No primeiro grupo focal os profissionais afirmam realizar alguns atendimentos e grupos compartilhados. No entanto, apontam impasses para o estabelecimento de ações compartilhadas, como aspectos relacionados à dificuldade de planejamento, ao pequeno número de vezes em que o NASF comparece à Unidade, à burocracia e à cobrança por quantidade de atendimentos.

\footnotetext{
E aí, como eles querem ter uma equipe, uma equipe de matriciamento na Unidade, pra ficar fazendo ação compartilhada, atendimento de uma hora cada um, sendo que a agenda deles é super apertada? Não é nem a nossa, porque a gente até tem uma flexibilidade pra atender, agora eles não. É consulta a cada quinze minutos... (Daniela, terapeuta ocupacional)

Agora até tem uma hora pra fazer compartilhada uma vez por semana. Mas assim, a minha agenda, por exemplo, cada paciente é de vinte minutos. A do doutor é de quinze. Então, assim, você ocupa a vaga de quatro pessoas no caso dele e três no meu, pra atender uma consulta compartilhada. E a questão não é essa, porque realmente é necessária aquela consulta compartilhada, é necessária aquela uma hora. O problema é que depois aquelas duas consultas você vai ter que dar um jeito de enfiar em algum lugar, né? Porque você vai ser cobrada por elas por conta do número. (Marta, enfermeira)
}

Os profissionais explicam que as ações compartilhadas acontecem "aos trancos e barrancos" e são mais frequentes quando existem ações específicas, como no dia da saúde da mulher, do idoso, do homem e em campanhas da vacinação. Um dos profissionais afirma que "é previsto aquela data para a execução do grupo, mas o grupo só acontece quando convém, por quê? A gente pensa que é por causa da produção, que é uma coisa quantitativa" (Miguel, educador físico) 
No que se refere ao planejamento, os profissionais afirmam que as reuniões de equipe com o NASF ocorrem apenas uma vez por semana e, além disso, há dificuldade em compatibilizar as agendas para atendimentos, já que os profissionais da ESF, principalmente o médico e enfermeira, possuem uma agenda determinada com tempo fixo e rígido para a realização de cada consulta. Segundo os relatos, a equipe é cobrada por um número determinado de atendimentos e, em situações em que há a inserção de uma atividade diferente, há a necessidade de realização de encaixes a fim de cumprir metas. A questão da falta de tempo para desenvolvimento das atividades é uma constante para esses profissionais.

Sobre as metas a serem atingidas, é interessante observar que, embora seja preconizado o trabalho em equipe, são estabelecidas metas individualizadas referentes às ações desenvolvidas por cada profissional. Há pouco espaço para registro de ações compartilhadas, exceto na ficha de produção do NASF. As ações individuais parecem mais valorizadas do que as que são desenvolvidas em conjunto.

Uma das agentes de saúde fala sobre o NASF:

\begin{abstract}
É que eles acabam sendo muito podados no trabalho. Muitas vezes, eu percebo que eles querem fazer mais, mas... Eu falo assim, é que eu vejo o trabalho deles e eu entendo o trabalho qual que é. E... assim, eu vejo que, às vezes, eles querem fazer coisa a mais. Mas é tipo que nem ela falou, na portaria é até ali que eles podem tá indo, né? Então, eu tiro pela população... você fala assim, ah... tem psicólogo lá, tem isso, tem aquilo. Daí você explica que, lá, eles vão trabalhar em grupo e eles não aceitam assim... É isso que eu falo... (Elisa, ACS)
\end{abstract}

Essa fala sugere que os profissionais da ESF consideram insuficientes as intervenções do NASF. A Portaria GM 154 do Ministério da Saúde determina, entre outros fatores, que os profissionais especializados devem oferecer apoio pedagógico e técnico-assistencial à ESF e é clara ao afirmar que o NASF não é porta de entrada para o sistema de saúde e que não se trata de um trabalho pautado na lógica do procedimento e das consultas e atendimentos ambulatoriais. A ACS refere que a portaria limita o trabalho desse profissional, que poderia atender a demandas na própria Unidade.

Os profissionais do NASF também falam sobre o trabalho compartilhado com as equipes de Saúde da Família:

Eu acho assim... que é muito delicado, que depende, é muito complicado isso, porque, por exemplo. Eu nunca fiz nada aqui... eu tô aqui desde novembro, eu nunca fiz nada com as auxiliares de enfermagem, nem 
visitas, as auxiliares não participam das reuniões, por quê? Têm outras funções, ficam tomadas, têm uma escala ' $x$ '... na hora das reuniões elas estão fazendo coletas, então, assim... isso eu acho que é uma coisa da instituição bancar. Então, na hora da reunião, suspende coleta, ou faz um rodízio entre as auxiliares, né? É... e aí a gente vai muito, pelo que eu vejo, de acordo com a disponibilidade do profissional. Então, tem enfermeira que a gente chega e fala assim: "Olha, a gente precisa fazer isso". Ela compra a ideia e aí ela interfere, ela valida essa necessidade e aí ela vai com agente, né? Outros, você corre atrás. Você fala: "Olha, mas precisa...". E aí, passa mês e roda a dupla que passa na reunião de equipe, bate no mesmo botão e a pessoa se torna inacessível, do tipo: "Mas a gente já passou esse caso pro NASF". E aí você retoma e a pessoa diz: "Minha parte eu já fiz, eu já passei pra você’. (Julia, psicóloga)

A psicóloga afirma que não há organização do trabalho que permita que todos os profissionais participem das reuniões de equipe e, em decorrência disso, acredita que as ações dependem da "boa vontade" de cada profissional. Essa dificuldade em organizar um trabalho articulado parece gerar a fragmentação das ações de cuidado, e cada profisssional intervém de acordo com determinada competência e, em seguida, encaminha o caso - "minha parte eu já fiz".

Mas eu acho que acontece isso que você está falando e as pessoas ficam tomadas pela rotina de trabalho, pela rotina da instituição, mas tem uma coisa... Eu acho que, na verdade, a questão é anterior, que é o planejamento das ações. Como é que se planeja algo sem estar todos os profissionais? Tipo olha... tem tal horário, se vira e me dá horário pra ontem... Então, assim, existe... mas acho que tem que existir planejamento em conjunto, estratégias em conjunto, partindo dessa organização inicial, de um plano de ação anual pra isso... (Adriana, fisioterapeuta)

A fisioterapeuta da equipe retoma a discussão sobre as ações compartilhadas, identificando a gestão do trabalho, ou seja, o planejamento em conjunto como elemento central para a realização do trabalho em equipe.

O gestor da Unidade Básica de Saúde e a própria gestão municipal de saúde são apresentados nas falas como figuras que devem "mandar", "organizar o trabalho" e exigir que ele seja feito.

E nessa Unidade, em particular, é muito difícil. Eu acho que tem um da gestão que... qual foi a proposta? O NASF tem que ter atendimento compartilhado. Vamos fechar... já que a dificuldade é a agenda, vamos deixar garantido lá, uma vez por mês... (Mirian, nutricionista)

E isso desde cima, né? (Adriana, fisioterapeuta)

Isso, uma coisa institucional... Secretaria da Saúde: "Vamos deixar separado o horário para que isso aconteça". Mas a gente sabe que isso não 
acontece. Então, fora isso a gente cai na disponibilidade da pessoa, se ela tá a fim. É o que a gente falou, se ela tá a fim, ela vai lá e topa... Se ela reconhece qual é o papel dela dentro daquele momento, né? Ela topa e vai junto e, se ela não topar, não rola e tudo bem por isso. Não existe nenhum tipo de discussão, isso não tem nenhum impacto pro serviço e ela continua tocando a agenda dela e a gente... (Mirian, nutricionista)

Por exemplo, eu acho que esbarra muito na gestão, porque assim... na outra Unidade, chegou uma médica nova e ainda... na segunda reunião que ela participaria, marcaram paciente pra ela. E ela entrou na reunião e falou: "Olha, gente, eu não posso ficar..." Eu fui falar com o gerente... Daí o gerente desmarcou todos os pacientes dela para aquele horário, desmarcou das outras semanas... o que já não acontec eu essa semana porque ela estava com agenda, né? Então, a gente esbarra nisso sim. (Julia, psicóloga)

Mas, mais do que verificar se existem ou não ações compartilhadas, é importante entender como elas se desenvolvem e o que compartilham os profissionais. Em uma das falas, a agente de saúde afirma que, em ações compartilhadas, sua função é ser mediadora de intervenções específicas do NASF, pois ela coloca em contato o sujeito e o profissional, possibilitando e facilitando o diálogo entre eles.

Ao questionar sobre o trabalho em equipe no campo da Saúde Mental e sobre as trocas estabelecidas entre os profissionais, o grupo expõe:

Eu acho que é difícil pra eles entenderem o que é uma patologia, o que é um transtorno mental... e perceber que este é o movimento e que eles vão ser exigidos o tempo todo. (Julia, psicóloga)

E a corresponsabilização do cuidado que eles não querem, eles querem a responsabilização, ou responsabilizam a equipe de NASF ou responsabilizam o próprio paciente. (Miguel, educador físico)

O grupo parece ser unânime em afirmar que os profissionais da ESF não têm conhecimento suficiente para lidar com o adoecimento mental e que não têm interesse em compartilhar os casos, mas sim encaminhá-los a um profissional especializado. Além disso, a equipe do NASF parece acreditar que os profissionais das equipes de Saúde da Família não querem aceitar uma nova forma de propor intervenções. Em alguns momentos, fica explícito que se estabelece um jogo de "cabo de guerra" entre as equipes.

Os profissionais da equipe técnica de saúde que deveriam se apropriar dessas ferramentas [Clínica Ampliada, Apoio Matricial e Projeto Terapêutico Singular] que a gente também precisa se apropriar, mas eles não querem se apropriar, né? Essa é a palavra, porque tempo eles têm, porque eles conseguem se organizar na agenda deles pra flexibilizar vários horários, não participando da reunião de equipe... porque ele tem um tempo ali que poderia ser o tempo utilizado pra apropriação dessa ferramenta... (Miguel, educador físico) 
Mas quem fala pra eles [profissionais da ESF) que eles têm que se apropriar disso? Só a gente. Eu acho que não é uma coisa institucional, só a gente... (Mirian, nutricionista)

Era isso que eu ia falar, daí fica o NASF contra o resto do mundo. (Adriana, fisioterapeuta)

Se não é a gente que tem que falar, alguém tem que falar, mas o tempo existe. Não existe disposição... (Miguel, educador físico)

Mas você já leu o documento norteador da equipe de Saúde da Família? (Mirian, nutricionista)

Ainda não, da equipe de Saúde da Família não, mas o nosso sim... (Miguel, educador físico)

Então, chega aqui e diz: "Olha vocês são do NASF, se virem e construam aí um jeito de trabalhar que é totalmente diferente do jeito como o serviço está colocado". Então, eu acho que aí vão vindo os entraves dentro da Saúde Mental, da Reabilitação, enfim, na assistência, enfim... em todas as áreas. Eu acho que quando alguém precisa falar pra enfermeira que ela... "olha aquele paciente, se ele não é hipertenso e diabético, ele tem outras coisas, que também... que você também pode olhar". E acho que isso pra todas as áreas, porque a gente tá focando, talvez, um pouco mais na equipe de Saúde da Família, mas acho que isso acontece com todos os profissionais. Eu acho que o NASF tem esse jeito político de ser, que a gente até se gaba, em alguns momentos, de dar conta. Olha a gente é maior descolado, a gente faz e acontece, não sei o quê. Mas é porque, como diz até a Karina [coordenadora do NASF], nós somos os primos hippies que a galera vê a gente aí... como se a gente tem um tempo livre... (Mirian, nutricionista)

De um modo intuitivo... (Fabiana, terapeuta ocupacional)

Ociosos, não fazem nada! (Adriana, fisioterapeuta)

Os profissionais falam da dificuldade em construir um modo de trabalhar, falam sobre os documentos norteadores, explicam que tais diretrizes existem, contudo, são pouco acessíveis.

Interessante observar que parece haver a necessidade de apropriação e aplicação da política conforme orientação dos documentos norteadores, mas de uma forma acrítica. Os profissionais parecem não questionar as diretrizes de organização do trabalho, não refletindo sobre o que é determinado. No entanto, eles reinventam o trabalho a partir dos recursos de que disponibilizam.

Diante da dificuldade em construir um modo de trabalhar em equipe, como será, para os profissionais do NASF, ficarem no lugar de suposto saber? Como será que lidam com o fato de serem cobrados a resolver os problemas de saúde da população atendida? 
E o nosso discurso tem que bancar isso, porque esse é o papel que deram pra gente, institucionalmente. Pelo menos no discurso, vocês têm que bancar um monte de coisas. Eu acho que na ação a gente se atravanca, porque o discurso e ação estão muito distantes um do outro. (Mirian, nutricionista)

O ideal está muito longe da realidade. Então, existem entraves institucionais, por exemplo, simples, mas que têm impacto, a garantia da presença do médico na reunião de equipe, né? Então, tipo, o cara não vai, marca consulta no mesmo horário... e a gestão que deve falar: "Escuta, faz parte da sua carga horária e você tem que entrar, né?" Então, você tem que ficar rendido e, pela falta do profissional, acaba abrindo as pernas, vamos dizer assim, pra... Cadê a gestão pra falar é assim e ponto, você tem que fazer? (Adriana, fisioterapeuta)

É o NASF que vai dizer? É o NASF que vai pegar o paciente, chegar e bater na porta e vai dizer: "Olha, vou atender com você?" Entendeu? Forçar um atendimento? Então, eu acho: que gestão é essa? Ela compreende, entende o processo? Ela garantiu o conhecimento do fluxo do trabalho? (Julia, psicóloga)

Essas falas possibilitam pensar sobre a responsabilidade delegada ao trabalho dos profissionais do NASF. Estes explicitam que as equipes de Saúde da Família depositam neles a responsabilidade de resolver os problemas de saúde dos casos discutidos e, diante disso, afirmam que mesmo quando não sabem o que fazer, eles têm que manter o discurso de que sabem, pois isso se relaciona à construção de confiança estabelecida entre as equipes. Além disso, sentem-se responsáveis por organizar o trabalho, por garantir a participação de profissionais na reunião e de garantir o atendimento compartilhado. Mais uma vez, queixam-se da ausência da gestão.

Se o médico não colocar a cadeira atrás da mesa e atender o paciente, como é que vai funcionar? Mas se a gestão pensa diferente, a coisa muda, o médico participa da reunião, o médico faz porque o horário tá separado... tem essa agenda e você faz consulta compartilhada... ele vai atender, faz diferença, né? Não é a gente que vai falar... (Miguel, educador físico)

Mas aí eu acho assim, há outras contradições... essa coisa da prescrição... porque existem normas de Saúde Mental falando, da assessoria de Saúde Mental, falando que o médico tem que cuidar dos casos leves daqui. Aí o médico se dá o direito de falar: "Não, não gosto, não gosto"; não sei, né?" (Mirian, nutricionista)

Tem médico que diz: "Eu não sou obrigado a prescrever tal medicação" [...] E aí? Não tem ninguém pra falar: "Você vai cuidar porque essa é sua atribuição". (Miguel, educador físico)

A prescrever tal medicação... Então, olha o buraco. E olha o cuidado. Que cuidado é esse em Saúde Mental? Então se, minimamente, for prescrição de medicamento, o paciente não acessa nem isso... (Mirian, nutricionista) 


\section{Sobre as relações e a gestão do trabalho}

A desigualdade entre os diferentes profissionais da Estratégia de Saúde da Família e do Núcleo de Apoio à Saúde da Família é um fator que interfere na efetivação da interdisciplinaridade, pois frequentemente essa desigualdade gera a dominação de determinados saberes sobre outros.

Observa-se a especialização e a diferença de capital simbólico, cultural e econômico entre os integrantes da equipe. Os profissionais que possuem conhecimentos técnicos e científicos bastante prestigiados pela sociedade costumam ter maior poder de decisão dentro da equipe e, além disso, recebem melhores salários. Os auxiliares de enfermagem e agentes de saúde muitas vezes se encontram submetidos a decisões das quais não tiveram participação, além de receberem remunerações muito inferiores a dos profissionais que apresentam formação acadêmica.

As situações abaixo demonstram como essa equipe lida com algumas questões relacionadas à tomada de decisão. Em algumas situações, as decisões são tomadas externamente à equipe.

Durante uma das reuniões de equipe, a enfermeira informou sobre uma nova organização das consultas médicas, esclarecendo que houve diminuição do número de consultas para crianças de determinada faixa etária. O médico, diante do exposto, perguntou o motivo da mudança e a enfermeira explicou que não sabia de que instância havia partido tal modificação, mas: "a ordem" seria essa. Em seguida, o médico replicou: “então, que seja feita a vossa vontade".

Nesse trecho parece haver uma situação em que a ordem é dada de maneira vertical. O médico fica sabendo que o número de consultas diminuirá, mas não entende o motivo para a mudança e na mesma hora acata a decisão dizendo "que seja feita a vossa vontade", ainda que em tom de queixa.

Frequentemente os auxiliares de enfermagem e agentes de saúde afirmam o desejo de realizar um curso acadêmico. Quando questionados sobre esse desejo, muitos dizem que querem obter um título para que tenham voz na equipe e para ganharem um salário melhor.

Quando as diferenças passam a assumir valores desiguais, tornam-se indesejadas, o que contradiz uma estratégia de atenção cuja base está no trabalho composto por diversos olhares e saberes.

A especificidade de cada núcleo de saber é importante para que haja um trabalho em equipe, no entanto, com frequência, cada campo de conhecimento assume um valor 
social diferente, e essas desigualdades extremas entre os saberes podem interferir tanto nas possibilidades de integração entre os profissionais como na interdisciplinaridade. Além disso, pode resultar na supremacia de uma determinada forma de agir em saúde, gerando ações cristalizadas e pouco criativas.

O trecho a seguir apresenta mais um elemento para a discussão sobre as relações de hierarquia entre os profissionais que compõem a mesma equipe.

Em um determinado momento da reunião de equipe, uma das agentes comunitárias de saúde se queixou de ter passado o filho em consulta com o médico de outra equipe. Relatou que tal profissional forneceu um atestado, para a criança, de apenas três dias, não tendo receitado remédio algum. Em seguida, a ACS lamentou que o médico de sua equipe não estivesse na UBS, naquele dia, para atender seu filho. Nesse momento, a enfermeira comentou que, se tivesse autorização, teria medicado o garoto e fornecido o atestado. A agente, em tom de brincadeira, perguntou, então, qual o valor e a função do carimbo da enfermeira se ela não poderia medicar e fornecer atestados. Respondeu a enfermeira: "não serve para muita coisa, mas serve para fazer sua avaliação a cada semestre".

$\mathrm{Na}$ medida em que alguns membros da equipe são responsáveis pela avaliação de desempenho de outros, fica colocada uma relação de hierarquia, não apenas relacionada à valorização dos diferentes conhecimentos. Instaura-se também uma relação de poder, inclusive sobre a permanência de determinados profissionais na equipe e no emprego.

Durante o primeiro grupo focal as agentes comunitárias de saúde discutem sobre o valor de seus conhecimentos perante a população que atendem e diante dos profissionais e da instituição que os contrata para prestação de serviços. A ACS Rosa comenta: "a nossa fala não vale muito pra eles. Eles não contam muito com a nossa fala", referindo-se à população atendida e aos profissionais da equipe. E outra ACS complementa:

\footnotetext{
Sabe? A gente fica... às vezes, a gente comenta assim, o que seria do PSF sem agente de saúde? O pessoal fala tanto que nós somos o topo, mas nós não somos o topo. Nós somos lá em baixo, porque ninguém reconhece a gente [...] nem pela remuneração, nem pela parte de... a gente sabe que têm profissionais que reconhecem, têm outros que não... Enfim, todo lugar tem, mas a entidade... (Maria, ACS)
}

Parece que a desigual valorização do saber se expressa não apenas na equipe, mas também nas relações com a população. Isso interfere nas discussões de casos, na construção de projetos terapêuticos e na possibilidade de constituição de ações compartilhadas e interdisciplinares. A diferença de saberes não é encarada como 
possibilidade de complementaridade, mas como algo que estrutura a hierarquia do saber, impedindo - ou pelo menos colocando-se como dificuldade - a realização da interdisciplinaridade.

A apresentação e discussão do caso clínico e dos temas - concepções sobre Saúde Mental; relação com o adoecimento; a prática, suas perspectivas e dificuldades e organização do trabalho - apontam que a prática e a integração das ações, no campo da Saúde Mental, entre os profissionais da ESF e NASF, são permeadas, entre outros fatores, por aspectos ligados às concepções sobre o adoecimento e às formas de relações que se estabelecem entre os profissionais e entre estes e os usuários da UBS.

As formas de compreender a Saúde Mental e o adoecimento mental aliadas à dificuldade em articular opiniões divergentes geram práticas contraditórias de intervenção entre os profissionais, o que interfere na organização do trabalho interd isciplinar.

Pudemos notar que a integração do trabalho entre as equipes ESF e NASF é perpassada por aspectos relacionados à comunicação; às poucas possibilidades de interação dos profissionais para a articulação de projetos terapêuticos, à valorização exacerbada da produção quantitativa de ações, à burocratização do trabalho, à valorização dos conhecimentos especializados e à fragmentação das ações, características marcantes da organização do trabalho em saúde.

A partir dos pontos destacados neste estudo, buscaremos estabelecer um diálogo com os referencias teóricos apresentados, a fim de produzir reflexões sobre como os profissionais se apropriam das diretrizes formuladas pelas políticas e constroem o trabalho interdisciplinar e em equipe para a consolidação da prática no campo da Saúde Mental. 


\section{DISCUSSÃO}

Em diálogo com o campo de estudos sobre o tema, interessa aqui pensar alguns elementos tais como as concepções sobre Saúde Mental, a relação com o adoecimento, a integração dos diferentes saberes para a realização da interdisciplinaridade, a organização do trabalho e a gestão dos serviços de saúde, buscando refletir como esses aspectos se relacionam ao campo da prática em Saúde Mental e ao trabalho em equipe no cotidiano dos profissionais da ESF e NASF.

Dentro dessa proposta, considerou-se interessante criar um espaço de reflexão que envolvesse alguns aspectos relacionados às concepções de Saúde Mental apresentadas pelos profissionais, bem como a relação que estabelecem com o adoecimento mental, pois é a partir do encontro dos técnicos com os outros técnicos e destes com os usuários dos serviços de saúde que a prática se desenvolve. Assim, interessa refletir sobre as expectativas e as condições em que esses encontros se dão.

A Saúde Mental como campo de conhecimento e de práticas propõe, a partir do diálogo com diferentes disciplinas e saberes, a desconstrução das instituições e ações da Psiquiatria clássica e a instauração de intervenções singulares que propiciem ressignificações na forma de compreender e lidar com o fenômeno do adoecimento mental. Nessa perspectiva, trazida por Scarcelli e Alencar (2009), busca-se a proposição de um lugar social para a loucura e sua manifestação.

A partir do diálogo estabelecido com os profissionais das equipes de ESF e do NASF, foi possível notar que estes, hegemonicamente, compreendem o adoecimento como fenômeno que envolve algum tipo de disfunção orgânica ou rupturas de comportamentos considerados normais.

Há entre os profissionais uma necessidade clara em estabelecer o diagnóstico, parte importante do processo de proposição do cuidado em saúde, pois é a partir dele que se desenvolverão as intervenções. Porém, em que concepções os profissionais se pautam para diagnosticar? Que tipos de intervenções desenvolvem a partir daí?

Os profissionais da ESF falam sobre isso, queixam-se da dificuldade em avaliar, definir e diagnosticar, pois nos casos relacionados ao campo da Saúde Mental, "não há exames laboratoriais" que auxiliem o diagnóstico. São criados então alguns critérios para a avaliação, e quanto a isso os profissionais arrolam uma série de características que atestam o adoecimento. A pessoa adoecida é aquela "que tira a roupa, que sai na rua, que ameaça e 
grita, agride", afirma o educador físico. Então, a doença surge "quando alguém fica agressivo, quando alguém precisa de internação", esclarece a ACS.

O adoecimento mental é também "uma coisa que incomoda" e, por fim, é fenômeno que "tem sim, esse desvio da normalidade, do comportamento aí, que afeta todo mundo [sic]”. Trata-se, portanto, de características que levam à classificação e que produzem ações pautadas na busca pelo restabelecimento do estado anterior ao adoecimento, do que é considerado padrão, normalidade. Os sintomas são tomados pelos profissionais como algo que é passível de ser enxergado, catalogado, classificado e, a partir disso, remediado.

Segundo Cavini (2012), em seu estudo sobre representações sociais relacionadas à família e Saúde Mental no contexto da ESF, os profissionais geralmente apresentam representações sobre Saúde Mental que se aproximam do modelo apresentado pela Psiquiatria clássica, na qual as ações de segregação e de negação da diferença orientam as intervenções em saúde, na busca pela normalidade. Essas representações se expressam na medida em que os profissionais identificam na diferença uma patologia e quando afirmam, por exemplo, que o adoecimento mental está relacionado a uma certa forma de comodismo apresentado por algumas famílias que possuem condições sociais muito precárias.

Há que se considerar que essas formas de compreender o adoecimento mental são hegemônicas, mas não únicas. Há outras compreensões sobre o adoecimento, como por exemplo, a trazida pela enfermeira da equipe ao afirmar que o adoecimento "não é só a tristeza em si, é a capacidade daquela pessoa de lidar com aquilo que faz com que ela adoeça ou não". Na perspectiva de tal profissional, os recursos da pessoa são percebidos como elementos importantes no processo de adoecimento.

Contudo, não é possível afirmar que haja, entre os profissionais, uma visão de que esses recursos dependem também das possibilidades de suporte oferecidas pelos serviços de saúde, de educação, de moradia, enfim, dos elementos que compõem a vida. Algumas concepções que buscam a transformação do olhar parecem não ter força suficiente para resistir ao que se propõe dentro da perspectiva clássica da Psiquiatria.

Há a busca pela superação de tal noção hegemônica, pois os profissionais se preocupam em discutir os casos com o objetivo de ampliar o olhar sobre o adoecimento, incorporando às discussões, além dos elementos ligados ao funcionamento orgânico e biológico, os aspectos familiares e sociais relacionados ao adoecimento.

Contudo, embora durante a elaboração do projeto terapêutico os profissionais se disponham a discutir sobre a complexidade dos aspectos envolvidos no processo de 
adoecimento - as questões familiares, por exemplo -, os olhares são produzidos dentro da lógica das especialidades, havendo pouca integração dos saberes para uma intervenção global.

Cada categoria profissional ocupa-se em olhar e intervir sobre um determinado aspecto do adoecimento. Isso ficou evidente na análise dos prontuários, pois foram observadas uma série de intervenções propostas por cada especialista. A pessoa com transtorno mental passa por consulta com o médico de família, com o psiquiatra - algumas vezes é atendida por mais de um psiquiatra -, recebe visita domiciliar da psicóloga, da terapeuta ocupacional e até mesmo da assistente social. Nesse tipo de abordagem, algumas condutas chegam a ser contraditórias ou duplicadas.

Entende-se que cada profissional detém conhecimentos específicos advindos de seus núcleos de formação. O que está em questão não é a inserção dos diferentes saberes, mas sim como eles se integram para a produção do cuidado em uma equipe multiprofissional.

Apesar de haver uma importante inserção de profissionais munidos de diferentes saberes, os olhares parecem estar voltados para os sintomas ou para as disfunções. Até mesmo quando se busca a compreensão sobre a complexidade envolvida no processo de adoecimento, as questões de ordem cultural ou social são analisadas sob o viés das faltas, das falhas, e desse tipo de olhar decorrem as intervenções prescritivas.

As intervenções ficam fortemente individualizadas. A terapeuta ocupacional do NASF afirma: "é que a gente, também, não está preparada pra tratar a família. Por mais que a gente conviva com isso no dia a dia. Falta um pouco de técnica de como fazer isso, tratar a família toda".

No que se refere às ações de cuidado oferecidas à família, tomam-se os integrantes desta como partes que devem obedecer às orientações oferecidas para que a intervenção tenha um "bom resultado".

A análise dos prontuários aponta para essa questão, pois frequentemente as abordagens familiares se dão no sentido de cooptar um dos membros da família para o estabelecimento do cuidado. Estabelecimento do cuidado não no sentido de compartilhamento, mas sim da determinação do que cada membro deve fazer, de como deve agir. Trata-se, portanto, de uma intervenção verticalizada. 
Compreende-se que a busca de auxílio familiar para o estabelecimento do cuidado não seja necessariamente indesejada, no entanto parece importante refletir sobre que tipos de concepções de cuidado e família estão implícitos na regência de determinadas ações.

Cavini (2012) aponta que os documentos norteadores da ESF, apesar de preconizarem o trabalho com a família, não determinam o que se entende por isso. A falta de definição e de construção de reflexões sobre a complexidade envolvida nas relações familiares leva os profissionais a operarem segundo suas próprias concepções, oriundas de seus universos culturais.

Segundo a autora, a possibilidade de realização do trabalho em equipe e o estabelecimento de diálogo e trocas são elementos que contribuem para que as concepções assumidas por cada profissional sejam revitalizadas e ampliadas, promovendo novas possibilidades de compreensão e atuação com as famílias. No entanto, apesar de os profissionais reconhecerem que o cuidado deve ser realizado junto ao grupo familiar, as ações ainda ficam restritas ao indivíduo.

Assim como a fragilidade de formulações e problematizações relacionadas às concepções sobre família são elementos que contribuem para que as ações em saúde sejam individualizadas e partam de ideias de senso comum, a pouca possibilidade de reflexões sobre como proceder diante do adoecimento mental gera o risco de que, nesse caso, os profissionais considerem que caiba qualquer tipo de intervenção.

A questão da prescrição diante do adoecimento mental merece atenção. Se por um lado os profissionais se queixam da ausência de exames laboratoriais para o estabelecimento de diagnósticos e da fragilidade de protocolos para a formulação da terapêutica, por outro lado há um excesso de prescrições e até mesmo um protocolo padronizado e pouco flexível. Essa questão se expressa na fala do médico de família ao descrever minuciosamente um caminho a percorrer diante do contato com o adoecimento mental, caminho que segue uma sucessão de passagens: o paciente "passa" suas queixas pro ACS que "passa" o caso para o médico que "passa" para o NASF que pode ou não "passar" para um serviço especializado em Saúde Mental.

Uma das terapeutas ocupacionais da equipe NASF define muito bem a cena que se desenvolve na produção do cuidado oferecido: "parece que é um paciente que é uma bomba-relógio, pode explodir a qualquer momento e... eu não quero estar por perto".

Quais são as condições que esses profissionais têm para lidar com tanta complexidade? Quais são seus recursos? 
O médico, ao descrever o procedimento que se desenvolve diante de um caso de adoecimento mental, aponta para algumas singularidades de cada caso e esclarece que, dependendo de como o adoecimento interfere na vida da pessoa e de sua gravidade, as ações são pensadas:

\footnotetext{
aí depende do paciente, o que ele tá sentindo, como tá interferindo na vida da pessoa... e, dependendo da gravidade, a gente pode estar indo na casa do paciente, a gente pode estar agendando uma consulta de encaixe, sem precisar a pessoa esperar muito tempo por isso.
}

De fato, o médico identifica que há diferenças "dependendo do caso", mas estas ficam atreladas à gravidade de cada caso, e não aos processos singulares do adoecimento e das consequências desse adoecer. Diante disso, as intervenções se restringem à visita domiciliar e à consulta. Dependendo da situação agenda-se antes, faz-se um encaixe, mas a intervenção é essa, a mesma em qualquer situação, é o protocolo.

A singularidade parece perturbar o que é conhecido e os profissionais acabam buscando aquilo que pode ser generalizado, as repetições, os padrões que possibilitem a proposição de intervenções conhecidas e respaldadas em êxitos atestados pelo saber científico, de situações já aplicadas previamente. É mais fácil lidar com o conhecido, com o sabido. As singularidades, geradoras de incertezas, teriam espaço dentro das propostas de trabalho da ESF e NASF?

A repetição das intervenções se apresenta também na análise dos prontuários. Para que a ampliação dos olhares e a inserção de diferentes profissionais em uma equipe, se as intervenções são protocolares? Faz-se a consulta, em que ocorre a prescrição de medicamentos, e em seguida busca-se atendimento especializado do psiquiatra ou psicólogo, com a expectativa de que estes saibam definir a melhor conduta a seguir.

Não se trata de negar a contribuição da biomedicina, dos conhecimentos em piscofarmacologia nem mesmo de subtrair as intervenções dos especialistas em Saúde Mental. Muitas dessas intervenções produzem efeitos importantes para a melhoria das condições de saúde da pessoa adoecida. O que nos interessa não é negar esse tipo de intervenção, mas sim de questionar a redução da prática a esse campo de ações, interrogando os automatismos que geram a medicalização das questões relacionadas ao sofrimento e às formas de viver das famílias. Trata-se de evitar uma aproximação das famílias guiada por olhares "patologizantes", criando possibilidades criativas de 
intervenções orientadas pela singularidade e pela potencialidade gerada no encontro entre o profissional e as pessoas adoecidas.

Trata-se ainda de investir no "algo a mais" apontado pelo médico ao falar sobre o cuidado em Saúde Mental. O profissional afirma ainda que, para o cuidado das questões relacionadas a esse campo de intervenções, "você precisa de uma sensibilidade um pouquinho mais... hum, mais... aumentada". Parece que as intervenções pautadas no paradigma hegemônico do modelo biomédico - exames laboratoriais, atendimentos psiquiátricos para a prescrição de medicamentos, internações, entre outros - embora muito utilizados, são insuficientes. Os profissionais afirmam que no caso de atendimento em Saúde Mental “[...] toda a equipe se mobiliza [...], tenta fazer todo um movimento e aquilo ali não dá em nada. É o que aparenta, né?"”

Certo é que o cuidado em Saúde Mental exige uma transformação de paradigma. Segundo Fernandes (1999, p. 95),

\begin{abstract}
ocupar-se da saúde mental significa, num primeiro momento, procurar conceituá-la deixando-a livre da herança clínico-médica que a reconhece sempre no eixo da saúde e doença e que indica as abordagens psicoterapêuticas como instrumentos de acesso e de definição sobre o seu caráter. Retirar a saúde mental do eixo terapêutico implica ressignificá-la no eixo da saúde social e conduzir a discussão à dimensão da subjetividade enquanto expressão das diferentes modalidades de subjetivação de nossa cultura
\end{abstract}

A busca pela ampliação das possibilidades de intervenção esteve presente nas reuniões de equipe por meio das trocas estabelecidas entre os profissionais da ESF e NASF, e nas tentativas de estabelecimento de diálogos com os profissionais de serviços especializados. Contudo, a multiplicidade de saberes presente em uma equipe de saúde não garante que o usuário do serviço de saúde terá um espaço em que seu sofrimento seja escutado para além dos sintomas.

Percebe-se a ampliação, entretanto, atrelada a uma conhecida lógica: as demandas dos usuários são avaliadas e catalogadas a partir das ações previamente estabelecidas por posturas e condutas que tendem à cristalização de ações e que buscam prioritariamente no saber científico produzido no campo da biomedicina a possibilidade de intervenção, o que torna as intervenções repetitivas, tendo como principal efeito a reiteração de paradigmas que se pretendia superar.

Parece que os profissionais já possuem algumas intervenções previamente estabelecidas e que o usuário deve se adequar e aderir ao que foi proposto, caso contrário, 
ele é visto como resistente ou aquele que não tem força de vontade. Por mais que haja avanços e tentativas de estruturação de novas formas de intervir, as ações prescindem de compartilhamento do projeto terapêutico com o usuário.

Ora, essa lógica contradiz a proposta da ESF, uma estratégia que deve se organizar a partir das demandas do território. Não se trata aqui de fazer denúncias ao funcionamento do serviço, mas sim de questionar os motivos que atravancam as possibilidades de reorganização do sistema de saúde a partir das necessidades da população e da estruturação de ações de promoção da saúde e prevenção de adoecimento.

A análise dos prontuários permitiu a observação de longos históricos de adoecimento em que se sucedeu uma série de encaminhamentos repetitivos. As intervenções pareciam não ecoar, pois a pessoa não seguia a orientação realizada.

Em um dos prontuários essa situação estava sinalizada. Uma das pessoas atendidas pela equipe foi encaminhada por mais de um profissional da ESF e NASF para acompanhamento psiquiátrico e, no entanto, os registros apontavam que a pessoa não estava comparecendo aos atendimentos com esse especialista. Apesar disso, a equipe mantinha a intervenção, alegando que "a pessoa não segue a orientação porque não quer ser tratada".

Frente a essa situação, faz-se necessário buscar a transformação das formas de olhar a saúde e o adoecimento. Com o objetivo de oferecer uma nova perspectiva sobre os processos de saúde e doença, Dejours (1986) propõe que o indivíduo seja colocado em lugar central, assumindo a responsabilidade por suas condições de saúde. $\mathrm{O}$ autor propõe, então, o des locamento da centralidade conferida ao saber científico e especializado sobre o processo de adoecimento - para ele, a saúde é sempre um assunto ligado às próprias pessoas.

Com base em estudos da fisiologia, o autor esclarece que os organismos nunca se encontram em estado estável e seria uma ação coercitiva buscar adequá-lo a determinadas formas de funcionar. Uma de suas contribuições é propor que o conceito de saúde seja formulado a partir da consideração de que o corpo, para ser saudável, necessita viver a variabilidade, a liberdade. No que se refere ao estado de saúde mental, afirma que a angústia faz parte dessa variabilidade, pois apesar de ser causadora de sofrimento, ela mobiliza mudanças e, por isso, "não se trata de acabar com a angústia, mas de tornar possível a luta contra ela, de tal modo que se resolva, que se acalme momentaneamente, para ir em direção a outra angústia” (DEJOURS, 1986, p. 8). 
Nessa perspectiva caberia aos profissionais e serviços de saúde a instauração de práticas que visam o fortalecimento das condições individuais, familiares e sociais de enfrentamento das situações de sofrimento e adoecimento. Trata-se da estruturação de ações que buscam, a partir da singularidade, auxiliar as pessoas a encontrarem meios para o enfrentamento de suas dificuldades e de seu processo de recuperação da saúde.

Dessa forma, vale apostar não apenas na ampliação, mas também na transformação de olhares sobre a saúde e o adoecimento, o que significaria favorecer a promoção de encontros para a produção e estruturação de brechas e de fissuras que viabilizam o aparecimento da complexidade dos processos de subjetivação e de produção de vida.

Frente a essa situação, Campos (2011) propõe que o trabalho no campo da saúde seja organizado de forma a viabilizar modos de agir em que o profissional possa se utilizar do conhecimento e das leis produzidas no campo da racionalidade tecnológica, mas que possa, sobretudo, modificá-la e transformá-la em função das características singulares de cada caso, "criando novos procedimentos em ato" (p. 3036).

As ações de cuidado em Saúde Mental são perpassadas ainda por questões relacionadas tanto ao estigma, preconceito e medo diante do estranho e do diferente representados pelas pessoas com transtorno mental -, quanto à frustração e impotência geradas pelas dificuldades em se estabelecer o diagnóstico e a terapêutica, bem como pela falta de profissionais e de serviços especializados de referência.

O estigma, o preconceito e o medo são questões relevantes, pois as concepções atreladas ao adoecimento e à pessoa doente determinam a forma como os profissionais se relacionam entre si e com a população atendida para o estabelecimento do cuidado. Algumas falas apontam para concepções moralistas, como a apresentada por uma das agentes comunitárias de saúde: “...eu lido até com drogado, mas com bêbado, eu chuto a bunda dele mesmo. Tá caído mesmo lá no chão e vai ficar, nem olho"

Segundo Ribeiro (2004), em seu estudo sobre famílias em situação de risco social, os profissionais assumem posturas ambíguas de proteção e repulsa diante do adoecimento, gerando ações pautadas em posicionamentos moralistas e até mesmo fóbicos.

Já a frustração e impotência foram mencionadas pelos profissionais como sentimentos relacionados à dificuldade no desenvolvimento das intervenções, frequentemente pouco eficazes e com poucos resultados que tragam melhorias nas condições de vida das pessoas atendidas. 
Os profissionais enfatizam: "a gente fica muito abalada com o problema da pessoa [...] mexe muito com o emocional da gente", porque "paciente de Saúde Mental, invariavelmente, entra em crise e tem uma dificuldade maior pra aderir...". E, frente a isso, expõem suas angústias diante das tensões que se colocam entre as intervenções e o que se espera delas: “... eu acho que vai apontando, também, muita impotência na equipe, porque por mais que eles invistam [...] esse investimento sempre cai no vazio. Acho que isso vai trazendo uma frustração pra eles, muito grande", "a gente se sente é... inválida, impotente, inválida, não sabe o que fazer... manda pra um lugar e não dá certo, manda pra outro lugar e não dá certo".

Os sentimentos de impotência e de frustração parecem se articular, entre outros fatores, com as expectativas dos profissionais. Os casos relacionados à saúde mental são aqueles em que "você precisa acompanhar muito tempo para perceber uma melhora" e, como afirma a enfermeira, "a dificuldade de trabalhar com essa questão de Saúde Mental é essa, você não tem o retorno que você espera ter de um caso".

Quanto a algumas dessas dificuldades, o apoio oferecido pelo matriciamento foi um aspecto apontado pelos profissionais da ESF como metodologia de trabalho importante para a construção de formas de olhar para o adoecimento. Uma das agentes comunitárias de saúde aponta: "o matriciamento é quando a gente começa a colher histórias, quando [...] eles falavam umas coisas, a gente falava outras [...] a gente foi juntando algumas coisas, algumas informações, formando, [...] começou a abrir mais a nossa mente".

Além disso, o Apoio Matricial foi reconhecido como instrumento que permite tanto a transferência de saberes ("aí o pessoal do NASF começou a explicar") quanto de orientação para a construção da intervenção ("a gente tá discutindo um caso e o pessoal do NASF fala: 'Ah, a gente pode fazer isso e isso e isso. Vocês podem fazer assim, assim e assado"”, como esclarecem as agentes comunitárias de saúde).

Vale observar que frequentemente a equipe NASF apontou as dificuldades que os profissionais da ESF apresentam ao lidar com o adoecimento mental, mas de um modo geral não se implicando na situação (“... por mais que eles invistam [...] esse investimento sempre cai no vazio. Acho que isso vai trazendo uma frustração pra eles, muito grande").

A relação de matriciamento parece ser polarizada entre aqueles que sabem - os profissionais do NASF - e aqueles que devem aprender - os profissionais da ESF. "A equipe de Saúde da Família não consegue dar conta desde questões mínimas... aí a gente precisa se mobilizar porque a gente sabe os danos que vai causar para o paciente a curto, a 
médio e a longo prazo, também", aponta o educador físico da equipe NASF. E em seguida acrescenta: "a gente não tem, às vezes, esse preconceito que os profissionais da Estratégia de Saúde da Família têm”.

Parece que os profissionais do NASF, como matriciadores, se colocam no lugar de quem detém o conhecimento, porém em outros momentos afirmam não ter clareza sobre o que exatamente seria a função de apoio. A nutricionista aponta que ao iniciarem o trabalho junto a ESF a sensação que tinham era de que teriam que construir uma forma de trabalhar e que se sentiam sem respaldo: "Olha vocês são do NASF, se virem e construam aí um jeito de trabalhar que é totalmente diferente do jeito como o serviço está colocado". A fisioterapeuta, então, sinaliza:

\begin{abstract}
o matriciamento ainda é o maior nó. Porque envolve aquilo tudo que a gente falou, né? Em que momento alguém chegou e falou: "matriciar é assim". Existe um senso comum? [...] Existe uma concepção, um padrão? Todos devem fazer assim? Ou fica no subjetivo? Isso é o maior nó. Não só pra Estratégia como pro próprio NASF, né? Eu acho que aí vai refletindo no processo, vai refletir no PTS, vai refletir em todos os demais, né?
\end{abstract}

Se por um lado os profissionais da ESF reconhecem que o apoio oferecido pela equipe NASF é importante para o estabelecimento de um cuidado compartilhado, por outro lado se queixam da burocracia do processo de trabalho e da fragilidade de uma rede de serviços especializados de retaguarda. Os atendimentos especializados e individualizados em Saúde Mental são almejados pelos profissionais da ESF, que afirmam que quanto maior a gravidade dos casos, maior a necessidade de um cuidado especializado.

Os profissionais do NASF afirmam ter dificuldades em desenvolver ações de prevenção de adoecimento e promoção da saúde, referindo que há uma alta demanda por atendimentos aliada à precariedade da rede. Além disso, têm que lidar com questões complexas, sendo "consumidos" pela demanda por tratamento das doenças graves. Por isso, dedicam-se aos que "gritam mais", aos casos considerados mais graves. Uma das terapeutas ocupacionais aponta que no cotidiano "têm aqueles que gritam e que ficam mais agitados e aqueles que, por outro lado, são os quietinhos, os deprimidos... que não chegam... porque não estão incomodando", e a fonoaudióloga complementa "até que ponto esses pacientes que são mais deprimidos, que ficam mais limitados ao lar, isolados, ficam na doença e só chegam quando, de repente, têm uma tentativa de suicídio?”. 
Essas situações apontam para algumas contradições colocadas para a ESF e NASF. Como desenvolver ações de promoção de saúde e de prevenção de adoecimentos e agravos - princípios de trabalho da ESF - diante de situações de imensa precariedade?

Esse é um dos questionamentos apresentados pela fisioterapeuta

\begin{abstract}
essa questão de promoção vai muito além do que a gente faz porque envolve outros setores, outras instituições, de... de educação, de moradia, cultura... Então, como você fala que o cara tá bem se ele não tem casa, se ele está desempregado, se ele tem uma série de problemas que vão desencadear em um sofrimento muito grande e ele não vai saber lidar com isso?
\end{abstract}

E, diante da complexidade e de tamanha fragilidade, os profissionais ficam limitados em suas possibilidades de intervenção, afirmando que não adianta executarem ações paliativas se não propuserem intervenções junto aos elementos que levam ao adoecimento: "como você vai tratar uma diarreia com um es goto a céu aberto do seu lado? Não tem como resolver aquele problema, né? Não adianta por um monte de vitaminas ali para ele tomar". Diante disso, os profissionais concluem que o problema é maior, "é uma questão social mesmo".

Embora a ESF seja uma estratégia de priorização das ações de prevenção de adoecimento e promoção de saúde, os profissionais apresentam como foco a doença. Os olhares e a preocupação estão na doença, e não no doente e seu contexto. E mesmo em situações em que há a ampliação do olhar e a percepção dos aspectos psicológicos, contextuais, culturais e sociais como elementos que interferem nas condições de saúde, por que as ações ainda ficam fortemente atreladas à doença?

Interessante notar que o excesso de demanda por atendimento aos casos graves é apontado pelos profissionais como um fenômeno que envolve aspectos do adoecer relacionado apenas ao indivíduo, e não como situação contextual.

Assim como o conceito de vulnerabilidade, formulado no campo da Saúde Coletiva e apresentado por Ayres et al. (2009), a gravidade pode ser pensada como fenômeno que envolve não apenas componentes individuais, mas também sociais e programáticos.

A vulnerabilidade é um fenômeno relacionado às chances que a pessoa tem de exposição ao adoecimento. Envolve, portanto, uma série de aspectos individuais como a qualidade de informações de que a pessoa dispõe sobre os riscos em adoecer atrelada a sua capacidade de elaboração e de incorporação em seu cotidiano no sentido de se proteger. 
$\mathrm{O}$ acesso aos meios de comunicação, à educação e às possibilidades de gerenciar sua vida, de tomar decisões políticas e de enfrentar barreiras culturais são aspectos relacionados ao componente social implicado na vulnerabilidade.

Por fim, e que muito nos interessa neste estudo, a vulnerabilidade é dependente do componente programático, ou seja, da organização e da disponibilização democrática de programas e serviços que visem à prevenção e o cuidado em saúde em determinados campos de intervenção.

Diante do exposto sobre a vulnerabilidade das pessoas em relação ao adoecimento mental, como refletir sobre a questão da gravidade? Ela estaria relacionada apenas aos sintomas, à capacidade do indivíduo em lidar com o adoecimento? Como organizar serviços e intervenções no sentido de fortalecer os aspectos programáticos envolvidos em situações de vulnerabilidade, evitando o agravo?

Estabelece-se, na ESF e NASF, um círculo vicioso. A precariedade das condições de vida associada à fragilidade das ações de promoção da saúde desencadeia processos de adoecimento que levam os profissionais a tratarem a doença e não terem condições para desenvolver intervenções de promoção. Estamos diante de um impasse e da seguinte questão: como operar transformações no olhar que engendrem ações direcionadas à obtenção de saúde e não apenas à eliminação da doença?

$\mathrm{O}$ adoecimento faz parte do viver, mas o olhar que temos e as ações que propomos é que irão determinar o quanto a doença trará mais ou menos prejuízos para o indivíduo/família.

Onocko-Campos et al. (2012), em seu estudo sobre a avaliação de estratégias inovadoras na organização da Atenção Primária em Saúde, relatam que os profissionais queixavam-se de que seu trabalho não era reconhecido e que eram convocados a lidarem com questões que envolviam uma complexidade relacionada a problemas que iam além da saúde física, como, entre outros, educação, moradia e desemprego. Queixavam-se também de que a doença era sempre o principal foco de intervenção, o que significava que tinham que se dedicar aos casos mais graves. A assistência e a alta demanda foram indicadas como os principais entraves para o desenvolvimento de ações de promoção da saúde e prevenção do adoecimento.

Os participantes deste estudo alegam ter que lidar com uma gama de situações que extrapolam o campo restrito à saúde, e diante disso a intersetorialidade é trazida como uma necessidade. Os profissionais relatam que realizam articulação com a rede de serviços 
especializados em Saúde Mental, porém tal relação é muito frágil, restringindo-se a reuniões em que há pouco espaço para o estabelecimento de um plano de cuidado em comum. Essas reuniões são tomadas por discussões sobre perfis de pacientes a serem atendidos em cada nível de atenção, como se a pessoa passasse a ser problema do outro e a corresponsabilização não fosse premissa do trabalho.

Nesse cenário, tanto na construção de projetos terapêuticos entre os profissionais da ESF e do NASF quanto na articulação com a rede de serviços, frequentemente o usuário não é incluído na produção de seu próprio cuidado, afinal, as intervenções e decisões são pensadas "por ele". Assim, o encontro com o usuário parece assumir uma relação quase sempre vertical em que o técnico, detentor de um saber científico, deve aplicá-lo da melhor maneira para atingir os "bons" resultados. Resultados que ele mesmo definiu sem que tivesse compartilhado com o usuário, o que gera falas como a apresentada por um dos profissionais: "parece que não quer ser tratada".

A análise dos prontuários nos permite verificar a baixa adesão dos usuários às intervenções propostas. As ações obedecem, em muitos casos, uma lógica em que a pessoa é encaminhada e reencaminhada para um mesmo tipo de intervenção e, quando, finalmente, ela adere, "pronto, podemos esquecer a Marlene, porque ela tava encaminhada, ela tá indo no CAPS".

Em um estudo sobre a participação da comunidade nas equipes de Saúde da Família, Crevelim e Peduzzi (2005) assinalam que as intervenções são fortemente pautadas nas lógicas do "pensar por", "decidir por" e "fazer por", e não no compartilhamento de decisões, que têm como premissa a discussão do projeto terapêutico e o estabelecimento do cuidado "com" os demais profissionais da saúde e usuários.

Merhy, Feurwerker e Cerqueira (2010, p. 61) apontam que:

essa relação empobrecida, em que o outro é tomado como corpo biológico
e objeto da ação e que deslegitima todos os outros saberes sobre saúde, é
vertical, unidirecional, como se prescindisse da ação/cooperação de quem
está sendo "tratado". Ou como se a cooperação fosse obtida
automaticamente a partir da "iluminaçãa" técnica sobre o problema e as
condutas para enfrentá-lo. Não é assim que as coisas funcionam na prática
e por isso mesmo tem sido tão difícil "conquistar adesão" às propostas
terapêuticas, sobretudo nas situações crônicas.

Essas questões parecem estar relacionadas, entre outros fatores, à tradição ocidental no campo da saúde, que toma o sofrimento humano como fenômeno reduzido a uma patologia que precisa ser diagnosticada, medicada e curada, gerando um processo 
denominado medicalização da existência e da vida (MERHY, FEUERWERKER, CERQUEIRA, 2010).

O processo de medicalização, como apontam Moysés e Collares (2001), transforma os problemas cotidianos e da esfera da vida em questões que se relacionam aos aspectos biológicos e individuais e que, portanto, são passíveis de intervenções clínicas no campo da saúde.

A pretensão de eliminar o sofrimento mental por meio de intervenções clínicas, de prescrições de medicamentos e de encaminhamentos para especialistas que possam resolver os problemas decorrentes do adoecimento mental são apontadas pelos profissionais da ESF e NASF. Os profissionais têm expectativas de resolver os problemas da população. De onde surgem essas expectativas de resolução? Como resolver?

Quando a busca é pela doença e pela produtividade/resolutividade, há pouco espaço para a escuta. Esse instrumento de intervenção parece ter sido suprimido do trabalho dos profissionais da ESF, o que fica expresso na fala de uma das agentes comunitárias de saúde: "a gente não tinha tanta ficha, tanta coisa pra perguntar e pra orientar... agora com tudo isso a gente não tem tempo de ouvir, de escutar as pessoas". O trabalho parece ter sido tomado pelos aspectos burocráticos, e a escuta, quando citada pelos profissionais, é compreendida como meio e não como fim - ela precede uma orientação, intervenção ou encaminhamento.

Sobre isso, Merhy, Feuerwerker e Cerqueira (2010, p. 61) assinalam que:

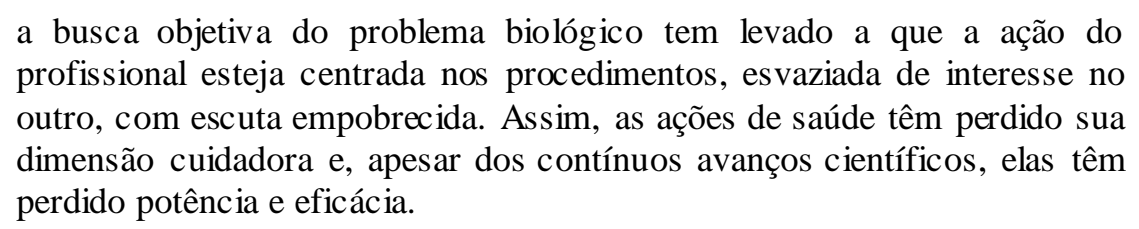

Ao refletir sobre a relação que os profissionais estabelecem com os usuários, pudemos notar que parece haver uma reprodução dessa forma de se relacionar também entre os profissionais da ESF e NASF. É possível dizer que tal como a população "não adere" às intervenções propostas, a ESF parece não aderir totalmente à proposta de trabalho apresentada pelo NASF. Essa situação se expressa quando os profissionais do NASF a firmam que "[...] a gente tá aqui, então, fingindo que tá pra fazer apoio, quando na verdade a gente faz sim... tenta cobrir um buraco da rede que é de assistência, né?" e 
quando a equipe NASF avalia que os profissionais da ESF "não querem corresponsabilização".

Da mesma forma como, muitas vezes, o saber do usuário sobre si próprio é silenciado no processo de elaboração do projeto terapêutico, resultando em uma imposição - estabelecida a partir de uma relação de poder em que se o outro não tem condições de agir acaba aceitando sem questionar aquilo que se propõe -, há pouca possibilidade de estabelecimento de trocas e de incorporação dos diferentes conhecimentos apresentados pelos diversos profis sionais que compõem as equipes ESF e NASF.

Merhy, Feuerwerker e Cerqueira (2010, p. 64) afirmam ainda a existência de uma tensão na relação entre os profissionais e os usuários dos serviços de saúde e que:

\begin{abstract}
essa tensão já existe mesmo quando o encontro entre um que diz ser dono do saber e o outro que vira seu objeto não é intencionalmente realizado com a ideia de um encontro intercessor, no qual todos entendem e topam sofrer os efeitos desse mesmo encontro e topam falar dele claramente, um para o outro. Porque não são poucos os relatos de experiências nas quais o chamado paciente desse encontro resiste às ofertas que o chamado trabalhador de saúde lhe faz.
\end{abstract}

Uma das estratégias para facilitar a circulação de conhecimento e de trocas de experiências entre os profissionais é a viabilização da comunicação entre eles por meio da realização de encontros periódicos.

As reuniões de equipe se constituem, então, como um espaço de excelência para o estabelecimento de comunicação, para o compartilhamento de saberes, para a formulação de projetos terapêuticos, para a pactuação de ações e planejamentos.

Tendo como referência os estudos sobre o agir comunicativo de Habermas, Peduzzi (2001) assinala que o trabalho em equipe é um tipo de trabalho pautado na construção de propostas coletivas, que se desenvolve em um campo de relações e intersecção entre as ações técnicas e as interações entre os sujeitos envolvidos. A comunicação assume um lugar central para a realização desse tipo de trabalho.

A integração do trabalho entre os profissionais que compõem uma equipe é perpassada por questões que envolvem a comunicação, a divisão de tarefas, a construção de um projeto assistencial comum, a compreensão sobre as diferenças técnicas como complementares e o caráter interdependente da autonomia técnica. Essas questões são focos de importantes estudos para a compreensão sobre a interd isciplinaridade. 
Nessa perspectiva de trabalho, a dimensão da intersubjetividade assume uma posição de destaque, não apenas no que se refere às relações entre os profissionais, mas também entre profissionais e a população atendida pelo serviço de saúde. Para a autora, a interação entre os profissionais acontece por meio da mediação simbólica da linguagem. A comunicação é então condição primordial para a integração dos diferentes campos de conhecimentos, para a articulação das ações e para a interação dos profissionais.

A estruturação de espaços para a comunicação entre os profissionais da ESF e entre esses e os do NASF, garantidos durante as reuniões de equipe que acontecem semanalmente, é um avanço no sentido de viabilizar as trocas de saberes e para o estabelecimento dos projetos terapêuticos. Contudo, foi possível observar que, nesses encontros, os profissionais ficavam absorvidos pela realização de trabalhos burocráticos como o preenchimento de fichas e de folhas de produção e pela redação de relatórios. Além disso, as reuniões eram atravessadas por questões que inviabilizavam ou, no mínimo, tornavam precárias as possibilidades de participação de alguns profissionais como os auxiliares de enfermagem e o médico. Esses profissionais, por diversas vezes, não participam desses encontros, pois são solicitados a realizar outras atividades no mesmo horário.

A burocratização e o estabelecimento de metas com priorização da dimensão quantitativa do trabalho parecem ser elementos que interferem e transformam as relações entre os profissionais e entre estes e a população atendida. Em um dos encontros a ACS disse que "antes a gente não tinha tanta ficha, tanta coisa pra perguntar e pra orientar... agora com tudo isso a gente não tem tempo de ouvir, de escutar as pessoas", e no segundo grupo focal a fisioterapeuta do NASF reafirmou ser "o tempo inteiro cobrada por papeis, por metas, por prazos, com datas... você acaba entrando na lógica do trabalho, na rotina".

Foi possível notar a prevalência de um modelo de gestão que prioriza o estabelecimento de contratos entre os gestores e os profissionais pautados na valorização da dimensão quantitativa. "O pessoal quer número, número, número. A saúde não se resume a número", lembra o médico. Ou, como afirma a enfermeira, "é a quantidade em detrimento da qualidade".

Frente a essa situação, interessa-nos refletir sobre os motivos que levam a esses espaços de encontros serem preenchidos pela parte burocrática do trabalho e pela valorização da dimensão quantitativa. Por que será que, mesmo havendo as reuniões, as 
trocas ficam comprometidas, sendo substituídas por outros elementos do trabalho? Por que a interdisciplinaridade, tão almejada, encontra tantas barreiras para sua realização?

Nota-se que os profissionais se dedicam à realização dos aspectos burocráticos do trabalho justamente porque são cobrados por desenvolver essas atividades. Não é possível negar que há uma exigência pela realização desse trabalho. Os gestores solicitam relatórios, o preenchimento de fichas de monitoramento das condições de saúde da população, o preenchimento de folhas de produção para o acompanhamento das atividades realizadas por cada profissional. Cobra-se esses aspectos do trabalho, porém muito pouco é avaliado sobre a qualidade das intervenções.

Mas, apesar dessa cobrança, parece haver uma adesão dos profissionais à realização dessas atividades burocráticas. O que faz com que os profissionais optem, muitas vezes, por executar essa parte do trabalho? Seria uma dificuldade em entrar em contato com as dúvidas, com o universo incerto do não saber o que fazer diante de algumas situações de adoecimento? Seria uma dificuldade em entrar em contato com as angústias geradas no processo de estabelecimento do cuidado?

Além das questões estruturais da organização do trabalho, nota-se a existência de elementos "invisíveis" que interferem na efetivação da comunicação e no compartilhamento de conhecimentos entre os profissionais. Tais elementos parecem estar relacionados às possibilidades de participação democrática da gestão do cuidado e da gestão do trabalho.

O médico da equipe comentou: "que seja feita à vossa vontade", em conversa com a enfermeira quando esta, ao retornar de uma reunião com os gerentes da UBS, relatou que haveria uma mudança na organização dos agendamentos. Quais são as possibilidades que os profissionais encontram para resistir às ordens provenientes das instâncias de gestão? Mesmo o médico, considerado o profissional que detém maior prestígio e poder perante a população e a equipe, encontra-se submetido a algumas ordens que são quase que religiosamente seguidas.

É certo que existem diferenças entre os conhecimentos e entre as categorias profissionais que compõem as equipes ESF e NASF. Essa diferença diz respeito ao núcleo de conhecimento e é desejada para que haja a interdisciplinaridade. No entanto, nota-se que as diferenças se traduzem em desigualdades extremas, colocando os profissionais diante de situações em que a composição de um plano assistencial pautado nos diferentes conhecimentos não é viabilizada ou estabelecida. 
As diferentes valorizações sobre os campos de saber corroboram para que se estabeleça uma relação que tende à dominação de alguns conhecimentos sobre outros. Alguns profissionais afirmam que seus saberes não são reconhecidos, que sua "voz não vale nada".

As relações de poder perpassam todas as questões apresentadas neste trabalho, desde a eleição de determinada forma de compreender a Saúde Mental e de determinar a melhor terapêutica até aspectos relacionados às possibilidades de comunicação, à viabilidade de realização do matriciamento, à elaboração compartilhada de projetos terapêuticos e implementação das ações, ao trabalho em equipe e a gestão do trabalho.

Os aspectos envolvidos na forma de relacionamento assimétrico que se estabelece entre os profissionais e usuários e entre as equipes de Saúde da Família e NASF nos permitem observar que há a supremacia dos conhecimentos científicos em detrimento daqueles apresentados pelos usuários e pelos agentes comunitários de saúde. Estes frequentemente se queixam de serem desvalorizados, de não terem voz no grupo e de não serem escutados pela população atendida. A queixa referente à desvalorização também se expressa nos planos salariais.

Esses profissionais, considerados peças-chave do funcionamento da ESF justamente por serem membros da comunidade e guardarem uma relação de identidade com a população atendida, assumem contraditoriamente uma posição de menor valor na equipe. Uma das agentes comunitárias de saúde expressa as ambivalências presentes no trabalho da ESF, questionando com muita pertinência: "o que seria do PSF sem agente de saúde?". E responde, ela mesma: “o pessoal fala tanto que nós somos o topo, mas nós não somos o topo. Nós somos lá em baixo, porque ninguém reconhece a gente [...] nem pela remuneração...”. E prossegue afirmando: "a nossa fala não vale muito pra eles. Eles não contam muito com a nossa fala".

Tal como o usuário é, muitas vezes, silenciado na construção de seu próprio cuidado, o ACS tem poucas possibilidades de contribuir com seus conhecimentos. Como modificar essa situação? Como fazer circular as diversas formas de olhar sobre o fenômeno do adoecimento? Ou mais, como produzir olhares que se debrucem sobre as possibilidades?

No cenário em que as desigualdades afetam as possibilidades de integração dos conhecimentos para a articulação do cuidado, Cunha e Dantas (2010, p. 38) assinalam que “o problema está em como utilizar esta energia investida na diferença de poder, de forma a 
aumentar a capacidade de análise e intervenção do grupo (e não na manutenção ou no aumento deste poder)".

As diferenças de poder se expressam nas formas de se relacionar entre os profissionais da ESF e NASF, interferindo nas possibilidades de estabelecimento de trocas. Os profissionais da ESF têm expectativas de "passar" o caso para o NASF e o NASF parece ter dificuldades em construir a "função apoio" para a qual foram solicitados "Isso é o maior nó, não só pra Estratégia como pro próprio NASF”.

Por que o choque de expectativas? Por que os profissionais do NASF afirmam que os as equipes de Saúde da família "não querem corresponsabilização", "querem passar os casos" e "querem resolver"? Ora, a ESF e NASF apresentam propostas de trabalho pautadas nos mesmos objetivos, tanto que o NASF de ve oferecer apoio. Por que, então, o desencontro entre o que a ESF deseja e o que o NASF pretende oferecer?

A proposta de implantação do NASF parece ter sido instaurada a partir de uma relação verticalizada. Isso fica claro quando os profissionais do NASF afirmam que há a necessidade de que as equipes da ESF realizem a leitura das diretrizes dessa política para que possam compreender o processo de trabalho proposto por esse dispositivo. Ou seja, isso nos faz questionar o quanto os trabalhadores da Saúde da Família puderam participar dos momentos de formulação dessa política e o quanto esse dispositivo responde e acolhe as necessidades e expectativas desses profissionais.

Os profissionais avaliam que a dificuldade de articulação das ações entre a ESF e NASF decorre da incompatibilidade de agendas dos profissionais, gerada por uma necessidade de produção quantitativa e por uma organização do trabalho que ainda privilegia os atendimentos individuais. Segundo eles, há diferenças relacionadas às metas de cada categoria profissional e ao tempo de atendimento para cada consulta.

A enfermeira explica a incompatibilidade de propostas de intervenções entre a ESF e o NASF. As agendas dos profissionais são incompatíveis entre si. O médico deve realizar atendimento com duração máxima de quinze minutos, a enfermeira tem que fazer consultas a cada vinte minutos, e os atendimentos realizados em parceria com os profissionais do NASF exigem um tempo maior. E uma das terapeutas ocupacionais questiona: "como eles querem ter uma equipe de matriciamento na unidade pra ficar fazendo ação compartilhada, atendimento de uma hora cada um, sendo que a agenda deles é super apertada?". Parece haver uma incoerência quanto ao que se propõe e o que se estabelece como meta. 
A nutricionista do NASF, ao discutir essa questão, relata que acredita que uma das soluções para a efetivação das consultas compartilhadas estaria em uma mudança de gestão, na garantia desse espaço a partir da gestão que programaria a agenda dos profissionais, viabilizando os atendimentos compartilhados. Parece que a gestão do trabalho é uma questão central.

Outra questão relacionada à organização do trabalho refere-se à ordenação das atividades dos profissionais, como a do auxiliar de enfermagem. Estes raramente participam das reuniões, pois têm que permanecer em outras atividades - acolhimento, coleta de exames, entre outros. Além das auxiliares de enfermagem, há fragilidades relacionadas à participação dos médicos nas reuniões de equipe. Isso expressa que as reuniões, espaços que viabilizam a comunicação, são pouco priorizadas.

Já a ausência dos médicos nas reuniões é justificada tanto por eles como pelo gerente da UBS como algo que se relaciona à necessidade de realização das consultas. $\mathrm{O}$ médico apresenta alguns privilégios no sentido de decidir como trabalhar e o que priorizar, tanto que durante a observação de uma das reuniões o médico da equipe diz não ter mais horários de consulta em sua agenda e, por isso, propõe que os atendimentos sejam feitos no horário de reunião de equipe. O educador físico da equipe NASF aponta que tal categoria profissional tem tantos privilégios que alguns chegam a afirmar "eu não sou obrigado a prescrever tal medicação" (referindo-se aos psicotrópicos), enquanto a nutricionista questiona: "olha o buraco. E olha o cuidado. Que cuidado é esse em Saúde Mental? Então se, minimamente, for prescrição de medicamento, o paciente não acessa nem isso?".

Parece que o impasse gerado entre as equipes se coloca, entre outros fatores, na metodologia de trabalho e na lacuna surgida entre o que a política pretende e o que se apresenta como possibilidade de intervenções técnicas, como respostas às demandas colocadas para a ESF. Há, aí, o que Amarante (1999) apontaria como uma lacuna entre o âmbito político-jurídico e o técnico assistencial. ${ }^{13}$ O NASF deve, segundo suas diretrizes, oferecer apoio por meio da lógica do matriciamento, e as equipes de Saúde da Família,

\footnotetext{
13 Amarante (1999) ao discutir sobre as questões relacionadas à Saúde Mental, afirma que essa área de intervenções é atravessada por quatro campos que se colocam em constante diálogo. São eles: o campo teórico-conceitual, que está relacionado à produção de conceitos e às teorias que definem o objeto de intervenção no campo da Saúde Mental; o campo técnico-assistencial, em que se dá a estruturação, as práticas e os serviços fundamentados no corpo conceitual formulado; o campo jurídico-político, que diz respeito às questões legislativas relacionadas aos âmbitos sanitário, civil e penal; e, por fim, o campo sóciocultural, ligado às produções culturais e às relações sociais estabelecidas com a loucura e co mo louco.
} 
diante de uma população bastante adoecida, almejam atendimentos individuais e desejam encaminhar os casos para os especialistas:

\begin{abstract}
Mas a demanda da equipe é muito grande, então eles querem passar o caso mesmo pra gente [...] e se desse para discutir um caso, eu acho que a resolutividade iria ser maior, mesmo que fosse demorar mais, porque quando a gente discute, todo mundo junto, um caso só, dá pra gente dividir as funções, as tarefas... cada um faz uma coisa. (Daniela, terapeuta ocupacional)
\end{abstract}

Como instaurar uma política que pretende a inauguração da produção de novos efeitos para as condições de saúde sem a participação dos profissionais e da população atendida?

O NASF apresenta como diretrizes a construção de um modelo de atenção orientado pela cogestão, mas ao mesmo tempo os profissionais afirmam desejar uma postura de gestão pautada no estabelecimento de ordens, desejam que o gestor faça cumprir os princípios do trabalho do NASF. Tais profissionais afirmam que necessitam que o gerente da Unidade Básica de Saúde "ordene", determine, "cobre" que as ações sejam feitas. Há uma ambiguidade colocada com relação ao tipo de gestão que os profissionais almejam. Há oscilações entre o desejo pela autonomia e a necessidade de um governo autoritário.

Percebe-se até aqui que os profissionais relacionam a dificuldade em realizarem o trabalho articulado à falta de tempo decorrente da demanda excessiva e da incompatibilidade de agendas, da burocratização do trabalho, da cobrança qualitativa e da assimetria dos profissionais em relação às possibilidades de utilizarem seus conhecimentos para a composição dos projetos terapêuticos.

Nota-se que ainda prevalece nos estabelecimentos de saúde, como apontam Cunha e Campos (2011), um modo de gerenciar pautado no modelo de gestão tradicional burocrático, em que há a tendência à padronização e à fragmentação das atividades, bem como à concentração dos processos de decisão. Haveria, assim, uma racionalidade gerencial tradicional e hegemônica que, ao centralizar as decisões sobre a organização do trabalho, contribuiria para que os profissionais reduzissem suas ações aos procedimentos relacionados às doenças ou partes do corpo.

Tal forma de gerenciar os processos de trabalho contradiz a possibilidade de compartilhamento e cogestão propostos pelo NASF. 
Diante da intensa assimetria que se instaura entre os profissionais no que se refere às possibilidades de gestão compartilhada do trabalho e frente à repetição dos modos de trabalhar em equipe e de se relacionar com o adoecimento e com a população atendida, como criar espaços para a criatividade, para a invenção que possibilite aos profissionais trabalharem de forma integrada e de acordo com as necessidades da população atendida?

Como apontamentos para reflexões, consideramos importante ressaltar o que Campos (2011) sugere como proposta de transformações para o estabelecimento do cuidado e das práticas em saúde. Para o autor, é fundamental que a relação entre a teoria e a prática em saúde seja pautada na racionalidade da práxis. Para ele,

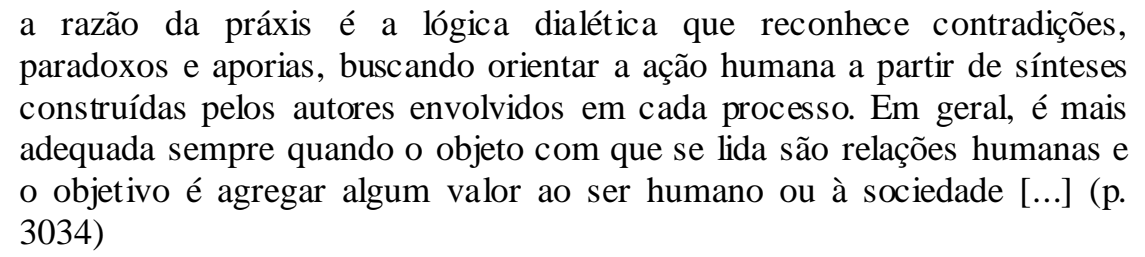

Trata-se de tensionar as repetições em busca das diferenças, das singularidades presentes tanto no encontro entre os técnicos para a realização de um trabalho que incorpore as diferentes formas de olhar sobre uma situação de adoecimento, quanto no encontro entre os profissionais e a população atendida pelas equipes de ESF e NASF. Como aponta Merhy, Feuerwerker e Cerqueira (2010, p. 70),

\begin{abstract}
é possível produzir diferença naquilo que se repete, assim como diz o poeta: repetir, repetir, repetir, até fazer diferente! O encontro que produz o cuidado deve ser sustentado por uma aposta de que é possível produzir diferença, mesmo ali, onde em princípio, nada se movimenta.
\end{abstract}

Certamente, há muito para se refletir e se discutir sobre os pontos elencados neste estudo. Observa-se que o NASF, ao propor o Apoio Matricial pautado na lógica da Clínica Ampliada e formular tentativas de produção compartilhada de projetos terapêuticos, produz brechas e algumas possibilidades de encontros entre os profissionais para a estruturação das intervenções no campo da Saúde Mental. Contudo, há ainda desafios para a estruturação do trabalho em equipe, desafios ligados sobretudo aos aspectos relacionais do trabalho em saúde. 


\section{CONSIDERAÇÕES FINAIS}

Esta pesquisa teve como objetivo a produção de um estudo que possibilitasse a construção de uma reflexão sobre a prática no campo da Saúde Mental a partir da observação da integração do trabalho realizado entre os profissionais da ESF e NASF. Para isto, buscou-se olhar para o campo de pesquisa por meio de diferentes fontes, com o objetivo de pensar as tensões, ambivalências e os pontos de ressonância relacionados a esses aspectos, presentes no cotidiano de trabalho.

Em diálogo com os trabalhadores de uma equipe de Saúde da Família e de uma equipe NASF, foi possível observar que as práticas desenvolvidas no âmbito da Saúde Mental são atravessadas pela maneira como os profissionais compreendem os processos de saúde e doença, ou seja, pelas concepções apresentadas sobre a doença mental. Tal encontro possibilitou notar que os profissionais apresentam concepções de Saúde Mental que se aproximam da lógica biomédica de compreender o adoecimento, o que significa que entendem o sofrimento psíquico como patologia. A partir disso, as ações propostas se dirigem à eliminação de sintomas e à sua medicalização.

As intervenções realizadas pelos profissionais são permeadas por preconceitos e valorizações morais. Algumas situações de adoecimento são compreendidas como "falta de vontade da pessoa" e empenho em se tratar. Alguns comportamentos são encarados como desvios de conduta, como no caso de situações que envolvem o uso de substâncias psicoativas.

Os sentimentos de frustração e angústia são também apontados como elementos que atravessam as relações de cuidado estabelecidas com a população atendida. Os profissionais relatam sentirem-se impotentes diante do fenômeno do adoecimento mental.

Foi possível notar que as questões que envolvem as concepções apresentadas pelos profissionais e a forma como se relacionam com as pessoas adoecidas são elementos importantes para a compreensão de como se desenvolve a prática, pois a partir do olhar construído sobre esses fenômenos é que os profissionais desenham suas intervenções e planejam os projetos assistenciais.

O contato estabelecido com os profissionais possibilitou ainda observar que tanto a prática em Saúde Mental quanto a relação que se estabelece entre os profissionais e entre estes e os usuários expressam os automatismos do agir gerados por uma determinada forma de olhar e compreender o adoecimento. Um olhar pautado no corpo (anatômico, psíquico, 
social), a partir de ordenamentos de funcionalidade e de padrões de normalidade. Formas de olhar e agir que, embora partam de diferentes núcleos de conhecimentos, apresentam a mesma perspectiva: a prescrição de ações que preconizam a eliminação daquilo que perturba o funcionamento.

Além dos aspectos relacionados à prática em Saúde Mental, este estudo pretendeu construir uma reflexão acerca da integração do trabalho entre as diferentes cate gorias profissionais que compõem as equipes de Saúde da Família e a equipe do Núcleo de Apoio à Saúde da Família.

Com relação à articulação do trabalho foi possível perceber que a implantação do NASF a partir de um arranjo tracejado pelas lógicas do Apoio Matricial, da Clínica Ampliada e do Projeto Terapêutico Singular, possibilitou a criação de brechas para a cons trução de intervenções pautadas no compartilhamento de saberes e experiências.

Contudo, alguns aspectos decorrentes da organização do trabalho, como a excessiva burocratização, a demasiada valorização dos aspectos quantitativos das ações, a instauração de relações desiguais e a instituição de modos de gerenciar pouco pautados na ideia de cogestão, tornam frágeis ou inviabilizam o trabalho em equipe e a interdisciplinaridade.

O estudo permitiu observar que as reuniões de equipe, espaços criados para o estabelecimento de trocas e articulação das ações, são inviabilizadas pela forma como se organiza o trabalho. Tais reuniões ficam tomadas pelos aspectos burocráticos do trabalho, pois os profissionais, frequentemente, utilizam o momento de encontro para 0 preenchimento de fichas e de folhas de produção, redação de relatórios, entre outros. Observa-se, assim a fragilização das possibilidades de comunic ação entre os profissionais.

Quanto às possibilidades de realização de atendimentos compartilhados, foi possível notar que as equipes apresentam dificuldades para a realização de tais atividades. Alega-se o excesso de demandas por atendimentos individualizados, a falta de tempo e a incompatibilidade de agendas entre os profissionais da ESF e do NASF como os principais fatores que interferem na realização de intervenções conjuntas.

Além dos elementos relacionados à organização do trabalho, foi possível perceber que as relações desiguais estabelecidas entre as diversas categorias profissionais acarretam a dominação de determinados campos de conhecimentos sobre os outros, empobrecendo as possibilidades de trocas de saberes e experiências. Geralmente, o cuidado em Saúde 
Mental fica limitado, reduzido a intervenções medicamentosas e a encaminhamentos para atendimentos especializados.

Ainda sobre a integração entre os profissionais das equipes de Saúde da Família e do NASF, o estudo possibilitou notar a existência de um choque de expectativas relacionado à construção do trabalho. Os profissionais do NASF afirmaram a dificuldade de aceitação dos profissionais da ESF em trabalhar a partir da ideia de corresponsabilização, solicitando a realização de atendimentos individualizados e especializados, o que condiz com a lógica de encaminhamentos.

Nesse cenário, é possível considerar que não basta que se instaurem novos modelos de atenção em saúde, é preciso ir além, é preciso criar espaços que permitam tensões e a formulação de brechas que valorizem os aspectos relacionais envolvidos no encontro entre os profissionais e entre estes e os usuários dos serviços de saúde.

Trata-se de buscar a produção de um cuidado que considere e ilumine a singularidade presente no encontro entre os diversos saberes produzidos pelos profissionais e pelos usuários, instaurando espaços para o acolhimento, para a escuta e para a criação de vínculos de corresponsabilidade.

Considera-se necessário a produção de um cuidado respaldado por diversas clínicas, o que significa colocar em pauta as possibilidades de criar brechas nas formas hegemônicas de intervir sobre as condições de saúde e de doença, convocando os profissionais de saúde a viabilizar o aparecimento da complexidade envolvida nos processos de adoecimento.

É importante que se estruturem brechas também no que se refere ao fortalecimento de arranjos organizacionais de trabalhos pautados na cogestão, pois a participação na construção de projetos e nas tomadas de decisões sobre o ordenamento do processo de trabalho favorece a corresponsabilização, fundamental para a estruturação de um trabalho integrado.

Para tanto, não há protocolos, não há receitas ou prescrições que sejam suficientes, é necessário que seja possível tanto aos profissionais da saúde quanto aos usuários enfrentar as angústias geradas na singularidade de cada encontro para a formulação criativa de formas de agir comprometidas com a construção compartilhada de projetos terapêuticos, de projetos de vida. 


\section{REFERÊNCIAS}

ALVES, G. G.; AERTS, D. As práticas educativas em saúde e a Estratégia de Saúde da Família. Ciência \& Saúde Coletiva, v. 16, n.1, p. 319-325, jan. 2011.

AMARANTE, P. Manicômio e loucura no final do século e do milênio. In: FERNANDES, M. I. A.; SCARCELLI, I. R.; COSTA, E. S. (org.). Fim de século: ainda manicômios? São Paulo: IPUSP, 1999. p. 47-53.

ANDRADE, L. M. B. et al. Análise da implantação dos Núcleos de Apoio à Saúde da Família no interior de Santa Catarina. Saúde \& Transformação Social, v. 3, n. 1, p. 18-31, jan. 2012.

AYRES, J. R. C. M., et al. O conceito de vulnerabilidade e as práticas de saúde: novas perspectivas e desafios. In: CZERESNIA, D.; FREITAS, C. M. (orgs). Promoção da saúde: conceitos, reflexões, tendências. 2 ed. Rio de Janeiro: Fiocruz, 2003. p. 117-139.

BOUSQUAT, A; COHN, A; ELIAS, P. E. Implantação do Programa de Saúde da Família e exclusão sócio-espacial no município de São Paulo, Brasil. Cade mos de Saúde Pública, v. 22, n. 9, p. 1935-1943, set. 2006.

BRASIL. Conselho Nacional de Saúde. Resolução no 196 de 10 de outubro de 1996. Aprova diretrizes e normas regulamentadoras de pesquisas envolvendo seres humanos. Brasília, 1996.

- Ministério da Saúde. Secretaria de Políticas de Saúde. Departamento de Atenção Básica. Programa Saúde da Família. Revista de Saúde Pública, v. 34, n. 3, p. 316-319, jun. 2000.

. Ministério da Saúde. Portaria GM no 336, de 19 de fevereiro de 2002. Estabelece CAPS I, CAPS II, CAPS III, CAPS i II e CAPS ad II. Diário Oficial da União, Brasília, 20 fev. 2002, n. 34, seção 1, p. 22.

Ministério da Saúde. Secretaria de Atenção à Saúde. Departamento de Atenção Básica. Política Nacional de Atenção Básica. Brasília: Ministério da Saúde, 2006 (Série Pactos pela Saúde 2006, v. 4). Disponível em: <http://bvsms. saude.gov.br/bvs/publicações/política_nacional_atencao_basica_2006.pdf $>$. Acesso em: jan. 2011.

Ministério da Saúde. Portaria GM no 154, de 24 de janeiro de 2008. Cria os núcleos de Apoio à Saúde da Família - NASF. Diário Oficial da União, Brasília, 25 jan. 2008, n. 18, seção 1, p 47-50.

- Ministério da Saúde. Secretaria de Atenção à Saúde. Departamento de Atenção Básica. Diretrizes do NASF: Núcleo de Apoio à Saúde da Família Brasília: Ministério da Saúde, 2009 (Série B. Textos Básicos de Saúde/Cadernos de Atenção Básica, n. 27). 
Ministério da Saúde. Portaria GM no 3.124, de 28 de dezembro de 2012. Redefine os parâmetros de vinculação dos Núcleos de Apoio à Saúde da Família (NASF) Modalidades 1 e 2 às Equipes de Saúde da Família e/ou Equipes de Atenção Básica para populações específicas, cria a Modalidade NASF 3, e dá outras providências. Diário Oficial da União, Brasília, 31 dez 2012, n. 251, seção 1, p. 223.

CAMPOS, G. W. S. Equipes de Referência e Apoio Especializado Matricial: um ensaio sobre a reorganização do trabalho em saúde. Ciência \& Saúde Coletiva, v. 4, n. 2, p. 393-403, 1999.

O anti-Taylor: sobre a invenção de um método para co-governar instituições de saúde produzindo liberdade e compromisso. Cadernos de Saúde Pública, v. 14, n. 4, p. 863-870, out.-dez. 1998.

A mediação entre o conhecimento e práticas sociais: a racionalidade da tecnologia leve, da práxis e da arte. Ciência \& Saúde Coletiva, v. 16, n. 7, p. 3033-3040, jan.-jul. 2011.

CAMPOS, G. W. S.; DOMITTI, A. C. Apoio Matricial e Equipe de Referência: uma metodologia para a gestão do trabalho interdisciplinar em saúde. Cade rnos Saúde Pública, v. 23, n. 2, p. 399-407, fev. 2007.

CAPISTRANO FILHO, D. O Programa de Saúde da Família em São Paulo. Estudos Avançados, v. 13, n. 35, p. 89-100, jan.-abr. 1999.

CARVAlHO, S. R.; CUNHA, G. T. Gestão da Atenção na Saúde: elementos para se pensar a mudança da organização da saúde. In: CAMPOS, G. W. S.; MINAYO, M. C.; AKERMAN, M.; DRUMOND, JR, M.; CARVALHO, Y. M. (orgs.). Tratado de Saúde Coletiva. São Paulo/Rio de Janeiro: Hucitec/Editora Fiocruz, 2006. p. 837-868.

CAVINI, P. N. Sobre família e saúde mental: as representações de profissionais da Estratégia de Saúde da Família (ESF). Dissertação (mestrado em Psicologia Social) - Instituto de Psicologia, Universidade de São Paulo, São Paulo, 2012.

CREVELIM, M. A.; PEDUZZI, M. Participação da comunidade na equipe de Saúde da Família: é possível estabelecer um projeto comum entre trabalhadores e usuários? Ciência \& Saúde Coletiva, v. 10, n. 2, p. 323-331, abr.-jun. 2005.

CRUZ, M. A. S. "A clínica e seus efeitos na subjetividade". Subjetividades Contemporâneas, v. 1, n. 1, p. 43-49, 1997.

CUNHA, G. T. A Construção da Clínica Ampliada na atenção básica. 2 ed. São Paulo: Hucitec, 2005.

CUNHA, G. T.; CAMPOS, G. W. S. Apoio Matricial e Atenção Primária em Saúde. Saúde e Sociedade., v. 20, n. 4, p. 961-970, dez. 2011.

CUNHA, G. T.; DANTAS, D. V. Uma contribuição para a co-gestão da clínica: GRUPO BALIN T PAIDÉIA. In. CAMPOS, G. W. S. et al. (orgs.) Manual de Práticas em 
Atenção Básica: Saúde Ampliada e Saúde Compartilhada. Hucitec, 2010, p. 2452.

DEJOURS, C. Por um novo conceito de saúde. Revista Brasileira de Saúde Ocupacional, v. 14, n. 54, 1986.

FERNANDES, M. I. A. Saúde Mental: a clausura de um conceito. Revista USP, n. 43, p. 90-99, 1999.

FRANCO, T. B., MERHY, E. E. Programa de Saúde da Família: contradições de um programa destinado à mudança do modelo tecnoassistencial. In: MERHY, E. E. et al. (orgs.) O trabalho em Saúde: olhando e experienciando o SUS no cotidiano. São Paulo: Hucitec, 2003, p. 53-124.

FRANCO, T. B.; GALAVOTE, H. S. Em busca da clínica dos afetos. In: FRANCO, T. B.; RAMOS V. C. (orgs.) Semiótica, afecção \& cuidado em Saúde. São Paulo: Hucitec, 2010. p. 176-200.

JAPIASSU, H. Interdisciplinaridade e patologia do saber. Rio de Janeiro: Imago, 1976.

LANCMAN, S.; BARROS, J. O. Estratégia de Saúde da Família (ESF), Núcleo de Apoio à Saúde da Família (NASF) e terapia ocupacional: problematizando as interfaces. Revista de Terapia Ocupacional da Universidade de São Paulo, v. 22, n. 3, p. 263-269, 2011.

LUCCHESE, R.; OliveIRA, A. G. B.; CONCIANI, M. E.; MARCON, S. R. Saúde mental no Programa Saúde da Família: caminhos e impasses de uma trajetória necessária. Cadernos de Saúde Pública, v. 25, n. 9, p. 2033-2042, set. 2009.

MATSUMOTO, N. F. A operacionalização do PAS de uma Unidade Básica de Saúde do município de São Paulo, analisada sob o ponto de vista das necessidades de saúde Dissertação (mestrado) - São Paulo: Escola de Enfermagem, Universidade de São Paulo,1999.

MERHY, E. E. O ato de governar as tensões constitutivas do agir em saúde como desafio permanente de algumas estratégias gerenciais. Ciência \& Saúde Coletiva, v. 4, n. 2, p. 305-329, 1999.

Um ensaio sobre o médico e suas valises tecnológicas: contribuições para compreender as reestruturações produtivas do setor Saúde. Interface Comunicação, Saúde, Educação, v. 4 , n. 6 , p. 109-116, fev. 2000.

MERHY, E. E.; FEUERWERKER, L. C. M.; CERQUEIRA, M. P. Da repetição a diferença: construindo sentidos com o outro no mundo do cuidado. In: FRANCO, T. B.; RAMOS V. C. (orgs.) Semiótica, afecção \& cuidado em saúde. São Paulo: Hucitec, 2010. p. 60-75.

MIELKE, F. B.; OLCHOWSKY, A. Saúde Mental na Estratégia de Saúde da Família: avaliação de apoio matricial. Revista Brasileira de Enfermagem, v. 63, n. 6, p. 900-907, nov.-dez. 2010. 
MINAYO, M. C. S. (org). Pesquisa social: teoria, método e criatividade. 22 ed. São Paulo: Vozes, 2003.

MOYSÉS, M. A. A.; COLLARES, C. A. L. Inteligência abstraída, crianças silenciadas: as avaliações de inteligência. Psicologia USP, v. 8, n. 1, p. 63-89, 1997.

NUNES, M.; JUCÁ, V. J.; VALENTIM, C. P. B. Ações de Saúde Mental no Programa de Saúde da Família: confluências e dissonâncias das práticas com os princípios das reformas psiquiátrica e sanitária. Cadernos de Saúde Pública, v. 23, n. 10, p. 2375-2384, out. 2007.

OLIVEIRA, G. N. O projeto terapêutico e a mudança nos modos de produzir saúde. 1. ed. São Paulo: Hucitec, 2008.

ONOCKO-CAMPOS, R. T. et al. Avaliação de estratégias inovadoras na organização da Atenção Primária em Saúde. Revista de Saúde Pública, v. 46, n. 1, p. 43-50, dez. 2012.

ORGANIZAÇÃO MUNDIAL DE SAÚDE. Relatório sobre a saúde no mundo 2001: Saúde Mental: nova concepção, nova esperança. Genebra: OPAS/OMS, 2001.

PEDUZZI, M. Equipe multiprofissional de saúde: conceito e tipologia. Revista de Saúde Pública, v. 35, n. 1, p. 103-109, fev. 2001.

RIBEIRO, E. M. As várias abordagens da família no cenário do programa/estratégia de Saúde da Família (PSF). Revista Latino-Americana de Enfermagem, v. 12, n. 4, p. 658-664, jul.-ago. 2004.

SAMPAIO, J. et al. O NASF como dispositivo da gestão: limites e possibilidades. Revista Brasileira de Ciências da Saúde, v. 16, n. 3, p. 317-324, 2012.

SANTA MARCELINA. Nossas unidades. Disponível em <www.aps. santamarcelina.org/aps/guainases.asp>. Acessado em: 02 de jan. 2011.

SANT'ANNA, S. R.; HENNINGTON, E. A. Micropolítica do trabalho vivo em ato, ergologia e educação popular: proposição de um dispositivo de formação de trabalhadores da saúde. Trabalho, Educação e Saúde, v. 9, supl. 1, p. 223-244, 2011 .

SÃO PAULO (cidade). Secretaria da Saúde. Diretrizes e parâmetros norteadores das ações dos Núcleos de Apoio à Saúde da Família - NASF. 2009. Disponível em: <http://www.prefeitura.sp.gov.br/cidade/secretarias/upload/saude/arquivos/esf/diret rizes_nasf.pdf $>$. Acesso em: 27 jan. 2013a.

Secretaria Municipal de Saúde de São Paulo. Mapa de distribuição das equipes de Saúde da Família e equipes NASF do Município de São Paulo. Disponível em: <http://www.prefeitura.sp.gov.br/cidade/secretarias/ upload/saude/arquivos/esf/equipes_esf.pdf> Acesso em: 27 jan. 2013b. 
SCARCELLI, I. R.; ALENCAR, S. L. S. Saúde Mental e Saúde Coletiva: Intersetorialidade e participação em debate. Cadernos Brasileiros de Saúde Mental, v. 1, n. 1, jan.-abr. 2009.

SCARCELLI, I. R.; JUNQUEIRA, V. O SUS como desafio para a formação em Psicologia. Psicologia: Ciência e Profissão, v. 31, n. 2, p. 340-357, 2011.

SCHRAIBER, L. B; et al. Planejamento, gestão e avaliação em saúde: identificando problemas. Ciência \& Saúde Coletiva, v. 4, n. 2, p. 221-242, 1999.

TANAKA, O. Y.; RIBEIRO, E. L.. Ações de Saúde Mental na atenção básica:caminho para ampliação da integralidade da atenção. Ciência \& Saúde Coletiva, v. 14, n. 2, p. 477-486, mar.-abr. 2009.

WESTPHAL, M. F. Participação popular e políticas municipais de saúde: Cotia e Vargem Grande Paulista. Tese (livre-docência) - Faculdade de Saúde Pública, Universidade de São Paulo. São Paulo, 1992.

YIN, R. K. Estudo de caso: planejamento e métodos. 4. ed. Porto Alegre: Bookman, 2010. 